\begin{abstract}
UNI VERSIDADE DE SÃO PAULO
FACULDADE DE FILOSOFIA, LETRAS E CIÊNCIAS HUMANAS

DEPARTAMENTO DE LETRAS CLÁSSICAS E VERNÁCULAS

PROGRAMA DE PÓS-GRADUAÇÃO EM LITERATURA BRASILEIRA
\end{abstract}

CESAR ADOLFO ZAMBERLAN

Dom Casmurro sem Dom Casmurro

São Paulo

2007

UNIVERSIDADE DE SÃO PAULO 
FACULDADE DE FILOSOFIA, LETRAS E CIÊNCIAS HUMANAS DEPARTAMENTO DE LETRAS CLÁSSICAS E VERNÁCULAS PROGRAMA DE PÓS-GRADUAÇÃO EM LITERATURA BRASILEIRA

Dom Casmurro sem Dom Casmurro

Cesar Adolfo Zamberlan

Dissertação apresentada ao Programa de Pós-Graduação em Literatura Brasileira do Departamento de Letras Clássicas e Vernáculas da Faculdade de Filosofia, Letras e Ciências Humanas da Universidade de São Paulo, para a obtenção do título de Mestre em Letras.

Orientador: Prof. Dr. Hélio de Seixas Guimarães

São Paulo

2007

Cesar Adolfo Zamberlan 


\section{Dom Casmurro sem Dom Casmurro}

Dissertação apresentada ao Programa de Pós-Graduação em Literatura Brasileira do Departamento de Letras Clássicas e Vernáculas da Faculdade de Filosofia, Letras e Ciências Humanas da Universidade de São Paulo, para a obtenção do título de Mestre em Letras.

Aprovado em:

Banca Examinadora

Prof. Dr.

Instituição Assinatura

Prof. Dr.

Instituição Assinatura

Prof. Dr. Instituição Assinatura 


\section{DEDICATÓRIA}

A minha mãe com enorme saudade

e a meu pai com enorme carinho. 


\section{AGRADECIMENTOS}

Ao meu orientador, o Prof. Dr. Hélio de Seixas Guimarães, pelo diálogo sempre muito pertinente e pela incansável dedicação nesses anos de convivência e trabalho.

Aos professores Roberto Moreira, Marcos Cesar de Paula Soares, Antonio Pasta, Alfredo Bosi, Ismail Xavier, Jorge de Almeida e Oswaldo Ceschin pelos conselhos sempre úteis e pelas indicações bibliográficas.

À minha família que sempre me apoiou e compreendeu minha ausência.

Aos companheiros da Faculdade Integração Zona Oeste (Fizo), do site cinequanon.art, do grupo de pesquisa "A recepção crítica do romance de Machado de Assis" e a todos os amigos que durante a realização desta dissertação deixaram de me ligar nos finais de semana para não me desviar do trabalho. 


\section{RESUMO}

ZAMBERLAN, C.A. Dom Casmurro sem Dom Casmurro. 2007. 178 fls. Dissertação (mestrado). Faculdade de Filosofia, Letras e Ciências Humanas, Universidade de São Paulo, SP, 2007.

“Dom Casmurro sem Dom Casmurro" tem como objetivo analisar o roteiro que a escritora Lygia Fagundes Telles e o crítico de cinema Paulo Emílio Salles Gomes fizeram a partir do livro Dom Casmurro de Machado de Assis para o filme Capitu (1968) do cineasta Paulo Cezar Saraceni. O livro que traz o tratamento do roteiro foi publicado pela Editora Siciliano, em 1993. A proposta do trabalho é comparar roteiro e obra, tendo como base os pontos principais levantados pela fortuna crítica do escritor, sobretudo os textos de Roberto Schwarz e John Gledson, e buscar um sentido, interpretar o conjunto de diferenças verificadas na passagem do livro ao roteiro para tentar entender a que tipo de leitura do romance de Machado de Assis as grandes e pequenas modificações promovidas pelo roteiro servem.

Palavras-chave: Literatura Brasileira, Machado de Assis, Dom Casmurro, Adaptação, Cinema. 


\begin{abstract}
ZAMBERLAN, C.A. Dom Casmurro Without Dom Casmurro. 2007. 178 pages. Inaugural Dissertation. School of Philosophy, Languages and Human Sciences, University of Sao Paulo, SP, 2007.
\end{abstract}

The aim of "Dom Casmurro Without Dom Casmurro" is to analyze the script written by author Lygia Fagundes Telles and film critic Paulo Emílio Salles Gomes based on the book Dom Casmurrro by Machado de Assis for the film Capitu (1968), by filmmaker Paulo Cezar Saraceni. The book containing the script was published by Editora Siciliano in 1993. This thesis will compare the screenplay and the book based on the central issues arising from the writer's critical fortune - especially the texts by Roberto Schwarz and John Gledson - and find a meaning as well as interpret the differences found in the adaptation in order to try to understand how the large and small changes in the screenplay can offer a different interpretation of Machado de Assis' novel.

Keywords: Brazilian Literature, Machado de Assis, Dom Casmurro, Adaptation, Movies. 


\section{SUMÁRIO}

$\begin{array}{ll}\text { Introdução } & 09\end{array}$

$\begin{array}{ll}\text { Machado de Assis e o cinema } & 14\end{array}$

O início do cinema no Brasil e a sua relação com a literatura $\quad 17$

As adaptações de obras de Machado de Assis $\quad 24$

A "intuição cinematográfica" de Machado de Assis $\quad 32$

\section{Primeira Parte}

1. O livro

1.1 A relação narrador X leitor $\quad 37$

1.2 Um registro da sociedade da época $\quad 41$

1.3 A relação forma e conteúdo $\quad 43$

\section{Segunda Parte}

2. A adaptação

2.1 Saraceni e a adaptação de Dom Casmurro 48

2.2 O roteiro e o livro $\quad 51$

\section{Terceira Parte}

3. Análise

3.1 Elementos para análise $\quad 60$

3.2 O livro que não está no roteiro 63

3.3 O livro que está no roteiro $\quad 71$

3.4 As principais diferenças 112

3.4.1. O narrador e o ponto de irradiação do foco narrativo 112

3.4.2. A reorganização dos episódios e suas implicações 114

3.4.2.1 J osé Dias e os outros agregados $\quad 115$

3.4.2.2 Bento Santiago 116

3.4.2.3 Capitu na janela 119

$\begin{array}{ll}3.4 .2 .4 \text { Os escravos } & 121\end{array}$

3.4.2.5 A paisagem como elemento de destaque $\quad 122$

3.4.2.6 A alteração no processo de leitura $\quad 124$

$\begin{array}{lr}\text { Conclusão } & 126\end{array}$

$\begin{array}{ll}\text { Referências Bibliográficas } & 132\end{array}$

$\begin{array}{ll}\text { Apêndice - Cotejo livro e roteiro } & 135\end{array}$ 


\section{NTRODUÇÃO}

“Dom Casmurro sem Dom Casmurro” pretende analisar um tipo especifico de leitura da obra Dom Casmurro de Machado de Assis: a que Lygia Fagundes Telles e Paulo Emílio Salles Gomes fizeram do livro e que serviu como pré-roteiro do filme Capitu (1968) do cineasta Paulo Cezar Saraceni.

A idéia de relacionar a obra do escritor com o cinema surgiu durante uma conversa no festival de Gramado - Cinema Latino e Brasileiro de 1997 com o professor Aníbal Damasceno Ferreira ${ }^{1}$. Professor Aníbal dizia que o cinema brasileiro sempre tinha sido muito injusto com Machado de Assis. Ainda pairava sobre Gramado a traumática e polêmica exibição de Quincas Borba (1987) dirigido por Roberto Santos. O filme foi mal recebido pela crítica ${ }^{2}$ e, abalado, Roberto Santos teve um infarto no aeroporto de Cumbica quando voltava a São Paulo.

A idéia de que o cinema brasileiro havia sido "injusto" com a obra de Machado de Assis traz uma outra questão, suscitada na época pelo professor Aníbal e, posteriormente, por outros professores de literatura e também de cinema com os quais conversei. Eles apontam a obra do escritor fluminense como "inadaptável". E isso, por uma série de motivos: a dificuldade do cinema brasileiro em fazer filmes de época, a

\footnotetext{
${ }^{1}$ Professor gaúcho, apreciador da obra de Machado de Assis e estudioso do teatro, cinema e literatura.

${ }^{2} \mathrm{O}$ então crítico da Folha de S. Paulo, Amir Labaki, escreveu na Folha em 3/5/1987 que "Machado de Assis deve ter se remexido no túmulo com a mesma intensidade que a platéia durante a interminável projeção de Quincas Borba" (apud SIMÕES, 1997: 192).
} 
dificuldade de recriar, no cinema, o mesmo ponto de vista do narrador machadiano, entre outros.

Analisar essa questão-chave, procurando hipóteses que expliquem por que as adaptações de Machado de Assis para o cinema não são tão bem-sucedidas, é uma tarefa por demais ambiciosa e extensa, nem tanto pelo número de filmes derivados da obra, mas pela complexidade do assunto. Tal estudo envolve o conhecimento da obra e da ampla fortuna crítica do escritor, o entendimento de seus procedimentos estilísticos, a função desses procedimentos quando se busca registrar uma sociedade e época e como é possível transpor esses expedientes e fins literários para uma outra linguagem.

Tal empreitada é plenamente justificada se tivermos em mente que Machado de Assis foi um dos maiores escritores de todos os tempos e que esta área, a da transposição da linguagem literária para o cinema e todas as suas implicações, é ainda carente de estudos, sobretudo no Brasil.

No entanto, para trabalhar este assunto é necessário fazer um recorte, visando a delimitação de um tema mais especifico, ao menos num primeiro momento.

A primeira idéia foi focar o trabalho numa obra em particular de Machado de Assis: Dom Casmurro. E essa escolha se baseava em quatro motivos: pelo fato de o livro ser um dos principais livros de Machado de Assis; por não ter encontrado nenhum outro trabalho que se detenha nessa adaptação - Memórias Póstumas já foi tema de outros trabalhos; pelo fato de o filme ter sido adaptado duas vezes ao cinema: a primeira por Paulo Cesar Saraceni com o nome Capitu em 1968 e a segunda por 
Moacyr Góes em 2003 com o nome de Dom e o quarto e fundamental motivo, pela existência de um livro com o roteiro do filme que foi dirigido por Saraceni, assinado pela escritora Lygia Fagundes Telles e pelo crítico de cinema Paulo Emílio Salles Gomes. O livro, editado em 1993 pela Editora Siciliano, revela uma etapa intermediária no trajeto do material literário para o fílmico e seria uma peça importante para a leitura que se pretendia fazer.

Tal recorte durou até o exame de qualificação, quando os membros da banca sugeriram que o trabalho se ativesse apenas ao roteiro e deixasse a análise dos filmes, tanto de Saraceni quanto de Moacyr Góes para um outro momento.

Sugestão aceita, dentro desse novo recorte, o objeto do trabalho passou a ser não a leitura que o cinema fez de Dom Casmurro, mas a leitura que Paulo Emílio Salles Gomes e Lygia Fagundes Telles fizeram do livro. Leitura que serviu de roteiro para o filme dirigido por Saraceni.

A intenção do trabalho, portanto, é analisar se os pontos principais do romance foram mantidos no roteiro; verificar as alterações que foram feitas, o que foi extraído e o que foi inserido; analisar se o roteiro modifica o contexto histórico e social em que se passam os acontecimentos narrados no livro; verificar se os temas apontados pela fortuna crítica do escritor em relação à obra ecoam no roteiro e, se não, por quê. $E$, finalmente, procurar compreender que sentido a adaptação atribui ao romance.

Todos esses pontos são citados porque é por meio deles que se pretende chegar ao objeto deste trabalho: a leitura que Lygia e Paulo Emílio fizeram do livro Dom Casmurro. A hipótese básica é que a leitura 
feita pelo casal ignora aspectos centrais da obra como o próprio personagem que dá nome ao livro e a partir do qual se articula a narração de toda a história de Bentinho e Capitu. Ignora-se o ponto de vista narrativo que estrutura um discurso "envenenado", para usar uma expressão de Roberto Schwarz (1997), e que tem como finalidade atar as "duas pontas da vida", usando como artifício para efetuar esse ajuste de contas - e fazer prevalecer a sua versão da história - a condição de proprietário, entre outras coisas, da faculdade e do direito de narrar.

Além desse aspecto central, veremos outras mudanças que mostram rumos diferentes seguidos por livro e roteiro. Daí resulta, talvez, a afirmação de que a obra é "inadaptável", quando, na verdade, o problema é a opção por expedientes que tornam os caminhos do livro e roteiro bastante desencontrados. Ainda mais em se tratando de um escritor que, como poucos, embaralhou o ponto de vista narrativo para dissimular aspectos centrais da história que narra, fazendo com que o leitor seja levado a aceitar, no contrato de leitura, uma visão da trama que é, propositadamente, parcial, ou que se revela, justamente, pelo que deixa de dizer ou por evocar o contrário do que está sendo dito.

Mas deixemos considerações de tal ordem para outro momento e tratemos dos métodos e procedimentos empreendidos nessa pesquisa para chegar à comprovação ou não da hipótese pretendida.

Essa dissertação é composta por três partes, mais a conclusão. A primeira chamada "O livro" trata dos principais aspectos do romance de Machado de Assis, levantados pela fortuna crítica do escritor. A segunda parte, "A adaptação", trata do percurso que motivou a adaptação do livro pelo cineasta Paulo Cezar Saraceni até ele contatar o casal Lygia Fagundes Telles e Paulo Emílio Salles Gomes para fazer o roteiro; além 
disso, analisa o processo de construção do roteiro a partir do texto publicado por Lygia Fagundes Telles na introdução do livro que tornou a peça pública. Essa introdução, que tem cerca de 10 páginas, foi intitulada, "Às vezes, novembro". Já a terceira parte é a análise propriamente dita e trabalha num primeiro momento com elementos teóricos que auxiliam no estabelecimento de uma comparação entre livro e roteiro; depois, ao fazer o cotejo entre livro e roteiro, estudo a parte de Dom Casmurro que não está no roteiro e a parte que está no roteiro, visando então, nos capítulos seguintes, levantar as diferenças entre o romance e a adaptação e entender quais novos sentidos essas mudanças implicam.

Foi fundamental para este trabalho a existência do livro com o roteiro do filme, assinado por Lygia Fagundes Telles e Paulo Emílio Salles Gomes. Na maioria das vezes, o roteiro é apenas uma peça que auxilia o diretor e a equipe durante as filmagens e não chega ao conhecimento do público. A edição do roteiro como livro é algo raro no mercado editorial e talvez tenha ocorrido pelo fato de ter sido escrito por duas pessoas de destaque em suas respectivas áreas e por ser um roteiro diferenciado, com enfoque mais literário do que costuma ser esse tipo de peça.

Para embasar teoricamente este trabalho, cito alguns dos principais críticos da obra de Machado, caso de Roberto Schwarz e John Gledson, e em especial os trabalhos destes sobre Dom Casmurro.

O pressuposto básico do ponto de vista teórico, defendido por vários estudiosos e adotado neste trabalho, é que toda e qualquer adaptação de uma obra literária para o cinema constitui uma outra obra. Obra que, se guarda parentesco com o livro fonte, não é e nem poderia 
ser uma reconstituição fiel do livro que a originou. Este trabalho centrase, portanto, não na necessidade de se ser fiel ao livro, mas nos pontos de contato entre uma obra e outra, ou seja, na leitura que foi feita e como ela foi feita.

Mas, antes de entrarmos nestas questões e no trabalho propriamente dito, é necessário situar melhor a relação entre Machado de Assis e o cinema e falar um pouco sobre as outras obras do escritor que foram adaptadas para esse meio.

\section{Machado de Assis e o Cinema}

Nos primeiros anos do século XX, o Rio de Janeiro de Machado de Assis passava por transformações profundas. Rodrigues Alves, o quinto presidente da República, assumiu o poder em 1902 e nomeou o engenheiro Francisco Pereira Passos como prefeito do Distrito Federal. A missão do prefeito, que acompanhou a reformulação de Paris entre 1863 e 1870, era remodelar o Rio de Janeiro, capital e principal centro econômico do país. Entre as obras, a modernização do porto, a criação de novas e amplas avenidas, melhorias no saneamento, no abastecimento de água e no fornecimento de energia elétrica, remodelando assim a capital que seria a vitrine de um novo país, mais moderno, mais civilizado.

Do ponto de vista urbano, a obra principal era a construção de uma nova avenida que cortaria o centro da cidade, ligando o centro 
comercial ao porto. Para a construção dessa avenida, a Avenida Central, que depois passaria a se chamar Avenida Rio Branco, centenas de casas e prédios foram demolidos, modificando significativamente a paisagem e a distribuição geográfica da população na cidade.

Machado de Assis, que tanto circulara pela cidade e que tão bem a conhecia, nada escreveu a respeito dessa mudança. Vivia o maior escritor fluminense um momento difícil com a doença e morte da esposa, Carolina.

Quem assinalou as mudanças que ocorriam no Rio foi outro escritor, Olavo Bilac. "Há poucos dias, as picaretas, entoando um hino jubiloso, iniciaram os trabalhos de construção da Avenida Central...", escreveu ele para a Revista Kosmos no início de 1904 (apud RICCI, Revista Nossa História, 2005). Entusiasmado pelo ar civilizatório da empreitada, Bilac foi além:

A cidade colonial imunda, retrógrada, emperrada em suas velhas tradições estava soluçando no soluçar daqueles apodrecidos materiais que desabavam. Mas o hino claro das picaretas abafava esse protesto impotente. Com que alegria cantavam elas - as picaretas regeneradoras! E como as almas dos que ali estavam compreendiam bem o que elas diziam, no seu clamor incessante e rítmico, celebrando a vitória da higiene, do bom gosto e da arte.

Alem das mudanças arquitetônicas, a cidade ganhava também novos componentes: os bondes passaram a dividir o espaço das vias com os automóveis, e as salas de cinema "tomavam" as ruas.

Machado, apesar de relutar, teria, segundo o relato de José Augusto de Lima, na autobiografia do pai, Augusto de Lima, andado em um automóvel (Apud PIZA,2005:361/362). Em novembro de 1907, 
Machado acompanhou Augusto, recém eleito à Academia Brasileira de Letras, ao Palácio do Catete, onde foram convidar o então presidente, Afonso Pena, sucessor de Rodrigues Alves, para a posse do poeta mineiro. Quando viu o automóvel, Machado teria dito: "Poderíamos ir de elétrico... teríamos mais tempo para palestrar". Ao final da aventura, Machado parece ter aprovado o passeio: "nunca pensei que fosse tão agradável".

Outra grande novidade na paisagem carioca era a presença cada vez maior de salas de cinema na Avenida Central. Olavo Bilac, na mesma Revista Kosmos, diz que em 1904 já havia na Avenida Central quatro ou cinco cinematógrafos, além de outras casas especialmente destinadas a esses espetáculos (apud CALDAS, 2006: 30). Ele conta que a "mania cinematográfica invadiu todos os teatros e tomou conta de todas as paredes e de todos os andaimes em que é possível esticar um vasto quadrado de pano branco". Diz ainda:

E daqui a pouco, não poderemos dar um passo pela cidade, sem encontrar diante dos olhos um desses lençóis alvos em que as cenas da vida humana aparecem deformadas pelo tremor convulsivo da fita, e onde as figuras de homens e mulheres aparecem atacados de delirium tremens ou de coréa, numa trepidação epilética.

Em 1907, com a regularização da distribuição de energia elétrica no estado, graças à entrada em funcionamento da primeira unidade provisória da Usina de Ribeirão das Lajes, da empresa Tramway Light Power, o número de salas de cinema na cidade cresce ainda mais. Só no segundo semestre, mais de 20 cinemas se instalam na Avenida Central (MOURA in RAMOS: 1990: 29). Antes disso, como atesta Paulo Emílio Sales Gomes, "o menor temporal ou ventania interrompia o 
fornecimento de energia elétrica" impedindo a exibição regular e comercial de filmes (GOMES, 2001:09).

Cada vez mais doente e com problemas na vista, Machado certamente não presenciou a chegada dos cinemas ao Rio e nem há registros de que tenha dito ou escrito algo a respeito da nova arte ou mesmo desse novo Rio de Janeiro que abria as portas para uma nova era. Quem disse foi um dos seus personagens, o Conselheiro Aires: “Já não sou mais deste mundo". Mas, como bem lembra Jean-Michel Massa, se "a obra é reflexo da personalidade do autor, não se pode afirmar sem precauções que a recíproca seja verdadeira" (1971:07). E assim, sem dizer ao certo, mas seguindo as palavras do conselheiro, Machado se foi às 3h45 da madrugada de 29 de setembro de 1908 .

\section{O início do cinema no Brasil e a sua relação com a literatura}

A relação de Machado de Assis com o cinema não ficaria, no entanto, apenas na coincidência de datas - morte do escritor e o aumento do número de salas de cinema graças à regularização do fornecimento de energia elétrica numa cidade, em tese, reurbanizada ${ }^{3}$. Com o desenvolvimento da linguagem cinematográfica era inevitável que obras do escritor fossem adaptadas para o cinema e, além disso, como ocorreu com outros escritores anteriores à invenção do cinema, houve quem dissesse, caso do escritor Magalhães Junior, que a obra do escritor fluminense continha uma intuição cinematográfica, antecipando expedientes estilísticos que o cinema depois usaria.

\footnotetext{
${ }^{3}$ Tanto Claudia Thurler Ricci no artigo já citado quanto Nireu Cavalcanti, que assina artigo na mesma revista, vão apontar que a remodelação da cidade não saiu completamente do papel por falta de recursos e de decisão política dos governantes da época.
} 
Mas demoraria 31 anos para o cinema adaptar a primeira obra de Machado de Assis. No caso, o conto Um Apólogo dirigido por Humberto Mauro. Mas antes, vejamos como se deu essa primeira relação entre cinema e literatura no Brasil.

\section{$\mathrm{XXX}$}

Uma reportagem, publicada pelo Jornal do Comércio, no dia 9 de julho de 1896, registra a primeira exibição de cinema realizada no Rio de Janeiro no dia anterior (MOURA in RAMOS, 1990: 15-16). O aparelho é um dos muitos similares ao cinematógrafo dos irmãos Lumière. A projeção ocorreu apenas alguns meses depois da projeção no Grand Café, em Paris, tida, oficialmente, como a primeira da história do cinema. A reportagem faz uma descrição minuciosa do funcionamento do aparelho.

OMNIOGRAPHO - Com este nome, tão hibridamente composto, inaugurou-se ontem às duas horas da tarde, em uma sala da Rua do Ouvidor, um aparelho que projeta sobre uma tela colocada ao fundo da sala diversos espetáculos e cenas animadas, por meio de uma série de fotografias. Mais desenvolvido que o Kinetoscopio, do qual é uma ampliação, que tem a vantagem de oferecer a visão, não a um só espectador, mas a centenas de espectadores, cremos ser este o mesmo aparelho a que se dá o nome de cinematographo (MOURA in RAMOS, 1990: 15).

Da sala de projeção:

Em uma vasta sala quadrangular, iluminadas por lâmpadas elétricas da Edison, paredes pintadas de vermelho escuro, estão umas duzentas cadeiras dispostas em fila e voltadas para o fundo da sala onde se acha colocada, em altura conveniente, a tela refletora que deve medir dois metros de largura aproximadamente. O aparelho se acha por detrás dos 
espectadores, em um pequeno gabinete fechado, colocado entre as duas portas de entrada. (MOURA in RAMOS, 1990: 15)

Da projeção em si:

Apaga-se a luz elétrica, fica a sala em trevas e na tela dos fundos aparece a projeção luminosa, a principio fixa e apenas esboçada, mas vai pouco a pouco se destacando. Entrando em função o aparelho, a cena anima-se e as figuras movem-se. (MOURA in RAMOS, 1990:15-16)

Da película exibida:

Talvez por defeito das fotografias que se sucedem rapidamente, ou por inexperiência de quem trabalha com o aparelho, algumas cenas movem se indistintamente em vibrações confusas; outras, porém, ressaltavam nítidas, firmes, acusando-se em um relevo extraordinário, dando magnífica impressão da ida real. Entre estas, citaremos: a cena emocionante de um incidente de incêndio, quando os bombeiros salvam das chamas algumas pessoas; a da dança da serpentina; a da dança do ventre; etc. Vimos também uma briga de gatos; uma outra de galos, uma banda de música militar; um trecho de boulevard parisiense; a chegada do trem; a oficina do ferreiro; uma praia de mar; uma evolução espetaculosa de teatro; um acrobata de trapézio e uma cena íntima. (MOURA in RAMOS, 1990: 15-16)

E no final faz um curioso alerta aos espectadores desavisados:

O espetáculo é curioso e merece ser visto, mas aconselhamos aos visitantes a se acautelarem contra os gatunos. Na escuridão negra em que fica a sala durante a visão, é muito fácil aos amigos do alheio o seu trabalho de colher o que não lhes pertence. A polícia que tão bem os conhece poderia providenciar no sentido de impedir-lhes a entrada naquele recinto.

A essa primeira exibição somaram-se muitas outras, mas se o “aparecimento do cinema na Europa Ocidental e América do Norte na segunda década dos anos 90 foi sinal de que a revolução industrial estava na véspera de se estender ao campo do entretenimento", como 
afirma Paulo Emilio Sales Gomes (GOMES, 2001:08), essa revolução demoraria a chegar ao Brasil.

Esse fruto da aceleração do progresso técnico e cientifico encontrou o Brasil estagnado no subdesenvolvimento, arrastando-se sob a herança penosa de um sistema econômico escravocrata e um regime político monárquico que só haviam sido abolidos respectivamente em 1888 e 1889. O atraso incrível do Brasil, durante os últimos cinqüenta anos do século passado e outros tantos deste, é um pano de fundo sem o qual se torna incompreensível qualquer manifestação da vida nacional, incluindo sua mais fina literatura e com mais razão o tosco cinema.

O cenário invocado por Paulo Emílio retardou o surgimento de salas de cinema no país e, de forma mais efetiva, a produção de filmes brasileiros. Vale a pena destacar que o autor ao usar a expressão "a mais fina literatura" cita de forma indireta a obra de Machado de Assis e estabelece um interessante paralelo entre o momento histórico e a relação cinema e Machado de Assis, assunto relacionado a este trabalho; por sua vez, quando cita o tosco cinema fala de um período em que a maioria dos filmes tinha um aspecto documental, muitas vezes, retratando notícias de jornal, fato que levou Olavo Bilac a prever como seriam os jornais do futuro.

Talvez o jornal do futuro para atender à pressa, ansiedade, a exigência furiosa de informações completas, instantâneas e multiplicadas seja um jornal falado e ilustrado com projeções animatográficas, dando a um só tempo a impressão audiovisual e visual dos acontecimentos, dos desastres, das catástrofes, das festas, etc. (Apud MOURA in RAMOS, 1990:20)

O cinema, porém, levaria ainda mais uma década para se firmar no Rio de Janeiro e isso só ocorreria com a regularização da distribuição da energia elétrica na cidade graças à entrada em funcionamento da primeira unidade provisória da Usina de Ribeirão das Lajes, da empresa 
Tramway Light Power, em 1907. Resolvido o problema de fornecimento de energia, o número de salas de cinema no Rio cresceu. Só no segundo semestre de 1907, mais de 20 salas de cinema foram instaladas na recém inaugurada Avenida Central. A abertura das novas salas obrigou os donos de cinema a produzirem mais filmes, contratarem técnicos do exterior ou técnicos brasileiros de outras áreas que se adaptaram à nova função para responder à demanda do público, cada vez mais interessado na sétima e mágica arte.

E é no ano seguinte à regularização da energia elétrica, no ano de 1908, que a primeira obra literária brasileira chega ao cinema. O fotógrafo português José Leal registra no palco do Circo Spinelli e leva para a tela a pantomima intitulada Os Guaranis, uma adaptação da obra O Guarani de José de Alencar feita pelo ator negro Benjamim de Oliveira que interpretava Peri. Sobre a adaptação, Moura (in RAMOS, 1990:33) afirma que esta primeira adaptação é uma referência fundamental para a construção da linguagem do cinema industrial.

Filmada ainda sem decupagem, com a câmera fixa, exprime as intenções e impasses desse cinema carioca para o qual a abertura de amplas possibilidades comerciais exigirá que técnicos e artistas se superem.

Em 1909, Leal e José Labanca produzem a adaptação de A cabana do Pai Tomás, de Harriet Beecher Stowe, dirigida por Antonio Serra, da qual se tem pouca informação.

Nesse período, o cinema brasileiro, além de trabalhar com filmes de atualidades, retratando fatos policiais, irá trabalhar também com operetas filmadas, os filmes cantantes: "musicais com a magia visual do cinema, cantados e tocados por músicos atrás da tela" (MOURA in 
RAMOS, 1990: 36). Mas anos depois, o cinema brasileiro passaria pelo que Roberto Moura (in RAMOS, 1990: 47) chama de "primeiro atropelamento", ou seja, um período de crise devido à concorrência dos filmes estrangeiros cuja indústria estava num patamar bem mais desenvolvido, o que exigia novos mercados consumidores para suas mercadorias.

Fora isso, mudava-se também o formato do produto. "O longametragem torna-se a partir de então o produto básico de exibição, exigindo grandes investimentos e um padrão de qualidade superior ao obtido com as câmeras e laboratórios aqui disponíveis" (MOURA in RAMOS, 1990: 45). Ao comentar ainda esse momento de crise, Moura lembra que o aumento da duração do filme pede narrativas maiores e mais elaboradas que os filmes de atualidade policial e operetas musicais, ou seja, narrativas mais próximas da estrutura e duração do romance, o que faz com que o cinema passe a adaptar romancistas da época e usar procedimentos narrativos típicos da literatura.

Os problemas de narrativas pendentes seriam superados por esse formidável produto comercial e cultural. Conseguindo incorporar com eficiência o molde do folhetim e do melodrama oitocentista, a narrativa permite, com as conquistas de Griffith da continuidade espaço-temporal, o encontro da técnica com a linguagem cinematográfica industrializável (MOURA in RAMOS, 1990: 45).

A partir da década de 10, vários livros brasileiros chegam às telas. Lulu de Barros ${ }^{4}$ que aprendera a fazer cinema em Paris, seria o autor daquela que é tida como a primeira adaptação de uma obra literária no Brasil. Em 1914, seis anos depois de O Guarani de José Leal, Barros

\footnotetext{
${ }^{4}$ Luiz de Barros, mais conhecido como Lulu de Barros, seria também o diretor do primeiro filme sonoro feito no Brasil, Acabaram-se os Otários (1929). Fez, segundo o IMDB, 81 filmes, entre 1914 e 1977, transitando por vários gêneros. O jornalista Sérgio Augusto o considera o precursor da chanchada. Barros morreu em 1981.
} 
filma A Viuvinha, também baseada em José de Alencar. Mas, o produtor Ítalo Dandini, decepcionado com o resultado artístico e o trabalho do laboratório, teria destruído a película antes mesmo de sua exibição (MOURA in RAMOS: 2000:48). Lulu de Barros filmaria mais dois livros de Alencar: Ubirajara em 1919 e Coração de Gaúcho em 1920.

Ainda nesse período, Antonio Leal dirigiu A Moreninha de Joaquim Manuel de Macedo em 1915 e produziu Lucíola, de José de Alencar, dirigido por Franco Migliani em 1916. Antonio Leite e Miguel Milano dirigiram Os Faroleiros em 1920, baseado em Urupês, livro de contos de Monteiro Lobato que havia sido lançado dois anos antes. Mas o diretor que mais faria filmes adaptados de obras literárias seria o italiano Vittorio Capellaro, que chegara ao Brasil em 1915 e dirigiria, no mesmo ano, Inocência de Visconde de Taunay; O Guarani, de José de Alencar em 1916; Iracema, também de Alencar em 1917; O Cruzeiro do Sul, baseado em O Mulato, de Aluízio de Azevedo, também em 1917; O Garimpeiro, baseado no livro de Bernardo Guimarães em 1920 e novamente O Guarani, de José de Alencar, em 1926, dessa vez com a co-produção da Paramount Pictures.

Diante desses dados e fatos, algumas considerações precisam ser feitas. A primeira é que, se na Europa as obras literárias chegam ao cinema logo na virada do século, no Brasil ela chegaria na década seguinte. Outra consideração, mais importante, é que a maioria dos escritores brasileiros adaptados nesse primeiro momento pertence ao romantismo, as duas exceções seriam Aluízio de Azevedo e Monteiro Lobato que chegam até de forma prematura ao cinema, sobretudo Lobato, se pensarmos na data de publicação de seus livros e na data de lançamento dos filmes. A terceira consideração é que J osé de Alencar foi o escritor mais adaptado nesse momento e é hoje juntamente com 
Nelson Rodrigues, o escritor de maior prestigio nos meios audiovisuais se levarmos em conta o número das adaptações. Uma quarta consideração a ser feita e que nos remete ao capítulo seguinte é que Machado de Assis, o maior escritor brasileiro, sucessor de José de Alencar e dos outros românticos, só foi ser adaptado em 1939 e ainda assim num curta-metragem dirigido por Humberto Mauro que adaptou o conto Um Apólogo, produção do INCE, Instituto Nacional de Cinema Educativo. Dos seus nove romances, o primeiro a ser adaptado foi Helena, que teve uma versão para televisão em 1952. Vejamos agora que livros de Machado de Assis foram adaptados e como foram feitas estas adaptações.

\section{As adaptações da obra de Machado de Assis}

A obra de Machado de Assis foi filmada pela primeira vez em 1939 e por meio de uma iniciativa do Poder Público. O Estado Novo passou a produzir filmes educativos cobrindo diversas matérias escolares, entre elas a literatura. Esses filmes foram feitos pelo INCE, Instituto Nacional de Cinema Educativo, criado pelo Presidente Getúlio Vargas por sugestão do Ministro da Educação Gustavo Capanema. O INCE passa a existir oficialmente em 13 de janeiro de 1937 e o seu chefe de Serviços de Técnica Cinematográfica era o cineasta Humberto Mauro. A partir de 1937, o instituto começou a realizar curtas-metragens educativos.

A poetisa Ana Cristina Cesar, que estudou a iniciativa em seu mestrado em comunicação "Literatura e Cinema Documentário", faz a seguinte análise das atividades do INCE: 
Cinema pedagógico e "dirigido". Ligado a uma preocupação oficial com a modernização da educação escolar; e a um ministro da Educação que atrai e protege artistas e intelectuais, integrando-os a um esquema de amparo oficial, no interior do contraditório regime estadonovista. A instituição e proliferação do cinema educativo se vincula a um ímpeto modernizante, organizante e centralizador do momento, num contexto em que a eficácia política parece definir-se basicamente por um impulso de organização sistemática, de "racionalização administrativa", e por uma expansão tecnoburocrática centralizadora (CESAR, 1980:15).

O dirigismo a que Ana Cristina se refere está ligado a uma visão oficial da literatura e a uma concepção oficial sobre a cultura, estabelecida pela

exaltação da personalidade do escritor e preocupação em fixar para a posteridade a imagem do vulto e dos fetiches que marcam sua presença ("registro da memória nacional"): berço, túmulo, objetos pessoais, iconografia familiar, caminhos que percorreu, tipos que conheceu, capa dos seus livros, prêmios recebidos, aclamações, belos bustos em bronze (CESAR, 1980: 15).

Ana Cristina afirma que o autor passa a ser uma figura histórica cuja biografia terá função edificante e exemplar e esclarece que a narração tem um texto enciclopédico que biografa a data e o local de nascimento do autor, família, formação escolar, amigos célebres, realizações, trajetos, obras escritas, data e local da morte e procura edificar os feitos do retratado. Machado de Assis era o "poeta e escritor perfeito, ainda não igualado"; a obra de Castro Alves, "um verdadeiro sol a iluminar os caminhos da liberdade". (CESAR, 1980:15).

Mas, contrastando um pouco com esse didatismo biográfico e edificante, a escritora cita a leitura que Humberto Mauro faz dos autores, sua biografia e obra apontam para uma leitura ingênua, “através da manipulação artesanalmente sugestiva (e não mais documental, descritiva) das imagens" (CESAR, 1980:15). Ela cita como 
exemplo o plano do mar agitado pelo movimento de um barco invisível para registrar a viagem de Castro Alves ao Rio de Janeiro e a sombra estilizada de escravos no trabalho para indicar a emoção que o cativeiro teria provocado no poeta quando menino. "Estas cenas não documentam nem comprovam a biografia: sugerem-na metonimicamente, rompendo o estrito aparato do filme conferência" (CESAR, 1980: 20).

A poetisa exalta o primitivismo dos filmes do cineasta que não disfarçam 0 artifício e nem se pretendem verdade natural. Elogia também a representação teatral que poderia até ser considerada ingênua em vista a sofisticação de documentários da época, 1980. Representação que foi usada para escapar ao rígido didatismo e à narrativa burocrática dos filmes feitos pelo Instituto. Para ela, o filme mais notável desta série é justamente o dedicado a Machado de Assis em 1939. Nele, após todas as explicações didáticas, Lúcia Miguel Pereira, crítica e biógrafa importante da obra e da vida de Machado, apresenta o conto Um Apólogo, dizendo que ele está no livro Várias Histórias. Após pronunciar a expressão "era uma vez...", que também inicia o conto, tem-se a representação com uma caixa de costura como cenário, e a agulha, a linha e o alfinete como personagens, reproduzindo o diálogo do conto escrito por Machado de Assis. Para Ana Cristina, "há uma invenção de bom humor nessa literatice" (CESAR, 1980:20).

A segunda adaptação de uma obra de Machado de Assis ocorreu em 1952 e não para o cinema, mas para a televisão. Trata-se do romance Helena, levado às telas pela TV Paulista, que anos depois seria comprada pela TV Globo. Essa versão tinha dois capítulos semanais que eram exibidos às terças e quintas feiras - as novelas só passaram a ter exibição diária em 1963. Nessa primeira versão de Helena, a atriz Vera 
Nunes fazia a personagem principal. Compunham ainda o elenco os atores Paulo Goulart e Hélio Souto.

Helena seria adaptada ainda outras duas vezes para a televisão. A segunda seria pela própria TV Globo em 1975, numa adaptação de Gilberto Braga, dirigida por Herval Rossano, que contou com 20 capítulos e tinha no elenco Lúcia Alves, Osmar Prado, Ida Gomes, Rogério Fróes, Ruth de Sousa, entre outros; e a terceira para TV, na antiga TV Manchete em 1987, dirigida por Luiz Fernando Carvalho, Denise Saraceni e José Wilker, numa adaptação de Dagomir Marquezi, Mario Prata e Reinaldo Moraes. A série tinha no elenco Luciana Braga, Thales Pan Chacon, Elias Andreato, Othon Bastos, Aracy Balabanian e Mayara Magri.

Hélio de Seixas Guimarães que estudou a adaptação de romances brasileiros para a televisão na sua dissertação de mestrado ${ }^{5}$ comenta que ao adaptar Helena em 1975 a TV Globo teria usado a trama também para fazer propaganda de um programa de alfabetização da época: o Mobral. No texto da novela, Helena incentiva o seu pajem a buscar instrução, a se alfabetizar (GUIMARÃES in PELLEGRINI, 2003: 107). Essa recontextualização da história em proveito de questões e temas da época da produção da adaptação será uma constante nas obras de Machado que chegam ao cinema e à TV.

Outro romance da primeira fase de Machado de Assis adaptado como novela de televisão é Iaiá Garcia. A primeira vez em 1953 também na TV Paulista, e a segunda pela TV Cultura, em 1982, numa adaptação

\footnotetext{
${ }^{5}$ Hélio Seixas de Guimarães aborda essa questão na sua tese de mestrado, "Literatura em televisão - Uma história das adaptações de textos literários para programas de TV", defendida no Instituto de Estudos da Linguagem da Unicamp em 1995.
} 
feita por Rubens Ewald Filho. A adaptação na TV Cultura fazia parte da série "Tele-Romance". Na época, a TV Cultura realizou um concurso, incentivando os estudantes a tecerem comparações entre a obra escrita e a adaptada para a TV. O romance ainda viraria um filme em 1977 com o título Que estranha forma de mar, dirigido por Geraldo Vietri.

Depois de laiá Garcia, em 1953, a obra seguinte de Machado de Assis a chegar às telas e, desta vez novamente aos cinemas, foi o conto "Noite de almirante", um dos quatro contos que compunham o longa Esse Rio que eu amo, feito em 1962 pelo argentino radicado no Brasil, Carlos Hugo Christensen. O episódio tinha no elenco Tonia Carrero, Agildo Ribeiro, Monah Delacy, Daniel Filho, Hugo Carvana, entre outros.

O próximo filme baseado numa obra de Machado de Assis foi justamente Capitu, de Paulo Cezar Saraceni, cujo roteiro feito por Lygia Fagundes Telles e Paulo Emílio Salles Gomes é objeto deste trabalho. O filme foi feito em 1968 e tinha no elenco a atriz Isabella, esposa de Saraceni, que fez o papel de Capitu, Othon Bastos como Bentinho, Raul Cortez como Escobar e Marília Carneiro como Sancha. Voltaremos a esse filme quando analisarmos o seu roteiro.

Dom Casmurro seria adaptado uma segunda vez ao cinema, mas só em 2003 com o filme Dom, de Moacyr Góes que foi livremente inspirado no livro de Machado de Assis e atualiza a história para os dias atuais. No filme, Bento chega a pedir um exame de DNA para saber se Ezequiel é mesmo seu filho.

Ainda em 1968, mesmo ano do filme Capitu, foi lançado o filme Viagem ao fim do mundo de Fernando Coni Campos. A película retrata uma viagem de avião da ponte-aérea São Paulo-Rio de Janeiro em que 
um dos passageiros lê Memórias póstumas, mais precisamente o capítulo do delírio de Brás Cubas, o que leva o diretor a recriar o episódio. O cineasta explica que achou estranha a idéia de encontra o livro numa banca de jornal do aeroporto.

Eu achei muito curioso as Memórias póstumas de Brás Cubas numa banca de jornal, numa edição de bolso. Machado de Assis no prefácio desse livro diz que Stendhal limitou o número de seus leitores a cem. Machado começa a se perguntar: "E eu, terei esses cem leitores de Stendhal? - Não, não terei cem leitores. Terei quando muito cinqüenta pessoas interessadas neste livro". E vai baixando, chega a dez, chega a cinco, vai para um ou talvez nenhum. E Machado de Assis, com aquela ironia, diz: - "Se eu tiver um leitor, pago-me a tarefa de ter escrito". No entanto, a sociedade de consumo transformou esse livro numa edição de bolso que estava à venda numa banca de jornal (CAMPOS, 2003:61).

O cineasta conta depois que comprou um exemplar e, ao lê-lo no avião, teve a idéia do filme.

Comprei. Entrei no avião, e, como era um livro que eu já conhecia bem, abri ao acaso. E abri exatamente num capítulo chamado "O Delírio". Este é não só um capítulo estranho no livro, como é estranho na obra de Machado de Assis... (...) Enquanto eu lia, olhei pela janela do avião, e certos detalhes da estrutura da asa me fizeram lembrar o dorso de um hipopótamo. E eu já estava voando, não no avião, mas no dorso de um hipopótamo. Ao meu lado, estava uma moça que lia uma revista de atualidades (CAMPOS, 2003:61).

Além do passageiro que lê Machado, o filme mostra ainda o pensamento dos outros passageiros: a moça que lê a revista de atualidades, duas freiras que discutem sua vocação religiosa e um jogador de um time de futebol que está sendo acusado de suborno.

Depois de Saraceni e Fernando Coni Campos, outro diretor a adaptar Machado de Assis foi Nelson Pereira dos Santos, que já havia feito em 1965 um curta-metragem documentário sobre Machado de Assis chamado O Rio de Machado de Assis. O filme é Azyllo muito louco, 
de 1971, baseado no conto O Alienista. A princípio, o papel de Simão Bacamarte seria de Chico Anísio, mas como o comediante queria fazer mais de um papel no filme, tal qual fazia na TV, Nelson Pereira dos Santos decidiu escalar outro ator.

O diretor explicou que decidiu filmar o conto por causa de 1968, do golpe dentro do golpe (SALEM, 1987:252). Para Nelson, a relação entre o alienista e a situação que ele construiu com o golpe era muito forte. O cineasta lembra da frase de Bacamarte: "Unamo-nos, e o povo saberá obedecer". Nelson Pereira voltaria a adaptar Machado em 1982 com um outro curta-metragem, desta vez baseado no conto A missa do galo. Sobre o escritor, o cineasta numa entrevista ao Correio da Manhã, em 6/07/1972, revela:

Nenhum outro dos nossos romancistas tinha tanto domínio da ironia, nem uma penetração psicológica tão admirável e segura. Seus personagens não são simples sombras saídas da imaginação de um ficcionista. São porta-vozes do pensamento de uma época, que sofreu alteração apenas exteriormente, mas estruturalmente permanece a mesma. Daí a atualidade de "O Alienista" que é quase um conto de antecipação (apud SALEM, 1987:253/254).

O Alienista foi adaptado ainda outras duas vezes. Em 1975, com o nome A Vila do Arco, numa novela da TV Tupi dirigida por Luiz Gallon, e num especial da TV Globo em 1993, dirigido por Guel Arraes e que tinha no elenco nomes como Marco Nanini, Giulia Gam, Milton Gonçalves, Cláudio Correa e Castro, Antônio Calloni, Marisa Orth, Sérgio Manberti e Luís Fernando Guimarães.

A obra seguinte de Machado de Assis a ser adaptada para o cinema foi o conto "Um homem célebre". O filme foi lançado em 1974, 
dirigido pelo cineasta Miguel Faria Jr., com o mesmo nome do conto e com Walmor Chagas no papel principal.

Ainda em 1974, chegou às telas a primeira adaptação de "A Cartomante", num longa-metragem do cineasta Mauro Farias. O filme foi dividido em dois episódios. Num deles o conto se passava durante o Segundo Reinado, e no outro foi atualizado para a década de 70. O filme ganhou o subtítulo "As regras do adultério". "A Cartomante" virou ainda uma minissérie na TV Globo no mesmo ano de 1974, dirigida por Domingos de Oliveira e Regina Duarte, e um longa-metragem, em 2004, dirigido por Wagner Assis e Pablo Uranga.

Curiosamente, a principal obra de Machado de Assis, Memórias póstumas de Brás Cubas, só chegaria ao cinema - se pensarmos na obra de maneira integral - em 1985. O filme, Brás Cubas, dirigido pelo cineasta Júlio Bressane, foi confessadamente inspirado em $A$ viagem ao fim do mundo de Fernando Coni Campos. Bressane até aproveita cenas desse filme quando o mesmo retrata o episódio do delírio de Brás Cubas. O trabalho de Bressane é considerado por críticos de cinema e estudiosos da obra de Machado de Assis como a melhor adaptação de uma obra do escritor para o cinema. Outro filme que adapta o romance Memórias póstumas de Brás Cubas é o filme de André Klotzel, chamado Memórias póstumas, feito em 2001, e que tem Reginaldo Faria no papel principal.

Machado de Assis foi adaptado ainda para o cinema em 1987, quando Roberto Santos adaptou Quincas Borba no filme que leva o mesmo nome; em 1994, quando Sérgio Bianchi adaptou o conto "A causa secreta", num longa que também ficou com o mesmo nome da 
obra literária, e em 2005 quando o mesmo Bianchi usou o conto "Pai contra mãe" no filme Quanto vale ou é por quilo?.

\section{A “intuição cinematográfica” de Machado de Assis}

Além de ter sua obra adaptada por vários cineastas, o nome de Machado de Assis esteve diretamente relacionado ao cinema em 1958, ano do cinqüentenário da morte do escritor, quando Magalhães Junior, crítico e biógrafo do escritor, e Paulo Emílio Salles Gomes discutiram uma suposta "intuição cinematográfica" de Machado de Assis. A idéia foi defendida por Magalhães J unior no artigo "A intuição cinematográfica de Machado de Assis", publicado no livro Ao redor de Machado de Assis, e criticada por Paulo Emílio no artigo "O narrador e a câmera", publicado originalmente no Suplemento Literário do jornal O Estado de S. Paulo de 27 de setembro de 1958.

No seu artigo, Magalhães Junior lamenta que Machado, doente da vista, não tenha se sentido atraído pela novidade do cinema quando ela chega ao Rio, pois a intuição cinematográfica do escritor, segundo ele, é "verdadeiramente impressionante". Segundo Magalhães, "não houve processo estilístico em cinema que ele não tivesse usado em seus livros" (MAGALHÃES, 1958:241).

Para provar tal afirmação, o crítico afirma que a técnica narrativa de Machado é a do primeiro plano e a do close up, e que Machado trata de alguns assuntos da mesma maneira que alguns mestres do cinema, caso de cineasta como Dreyer, John Ford e Hitchcock. Magalhães afirma que em Machado o cenário é quase sem importância, a câmara, escreve ele, "como que agarra os personagens, enfocando-Ihes as expressões, 
os esgares, os trejeitos, numa perseguição implacável" (MAGALHÃES, 1958:241).

Magalhães continua seu raciocínio afirmando "que Machado realiza com palavras verdadeiros instantes cinematográficos, não porque esses instantes se prestassem a filmagens, mas porque antecipadamente usou em tais momentos os meios que o cinema mais tarde iria pôr em voga" (MAGALHÃES, 1958:242) e cita como exemplo a questão da técnica do flashback que Machado usa em vários romances e que seria depois incorporada pela linguagem do cinema.

Magalhães cita ainda o episódio do delírio de Brás Cubas e a fusão de imagens que o livro evoca, alegando que a leitura deste episódio é uma experiência tipicamente de cinema. Outro exemplo da técnica cinematográfica em Machado estaria no capítulo seguinte ao delírio, "Transição", no qual Machado em poucas linhas associa o episódio de Virgília a um pecado de juventude, para passar a falar não da sua juventude, mas do seu nascimento.

O critico descreve ainda várias outras cenas dos romances e contos de Machado, mostrando de forma entusiasmada como elas poderiam ser decompostas em planos cinematográficos. Lembra da lápide de Nhá-loló em Memórias póstumas que é apresentada no livro como uma imagem, um close, diz ele. Tal close seria "o espírito da síntese de uma narrativa cinematográfica” (MAGALHÃES, 1958:246). Magalhães cita também passagens em que Machado transforma pessoas em bichos por efeito de uma alucinação, caso do conto "Decadência de dois grandes homens", e compara tal artifício à cena em que Carlitos, esfomeado, teria transformado seu companheiro num enorme peru (sic). Finalizando o texto, Magalhães Junior escreve que "não houve 
outro escritor brasileiro que apresentasse uma gama tão rica de associações e dissociações de imagens" (MAGALHÃES, 1958:246).

O artigo de Paulo Emílio sai no mesmo ano da publicação do livro de Magalhães Júnior. Paulo Emílio revela que sente uma espécie de pasmo e admiração pela fecundidade do trabalho do escritor, visto que sempre encontra um novo livro deste quando visita as livrarias. Diz que procurou o texto de Magalhães por dever do ofício, pois solicitaram a ele, devido ao cinqüentenário da morte de Machado, que ligasse o nome do autor de Dom Casmurro ao cinema.

Paulo Emílio registra que ao ler o texto notou dois erros de informação. Na cena do filme de Charles Chaplin, citada por Magalhães, não é Carlitos que vê o companheiro transformado em um animal, é ele que se transforma, e o animal não é um peru, como afirma Magalhães, mas um frango. Paulo Emílio escreve isso porque acha que os deslizes do ensaísta mostram que ele não tem muita familiaridade com o tema cinema, apesar de ter trabalhado como tradutor de filmes.

O critico do jornal afirma então que os argumentos de Magalhães são inconsistentes e passa a rebatê-los. Sobre a técnica de Machado ser a do primeiro plano ou close, sem uma importância maior da cenografia. Paulo Emílio diz que não consegue abstrair a aventura de Bentinho e Capitu da casa de Matacavalos, da mesma forma que não consegue abstrair o cenário da ação dos filmes de Dreyer, Ford e Hitchcock. Escreve ainda que a noção de planos em Machado de Assis é das mais variadas e ele não trabalha apenas com planos fechados.

Sobre os flashbacks, Paulo Emílio escreve que a liberdade de composição com referência à cronologia era corrente na literatura e cita 
como exemplo os memorialistas, em especial Rousseau, e Eça de Queirós, mais precisamente o livro Os Maias. Para Paulo Emílio, faltou a Magalhães Junior uma reflexão mais acurada sobre o tema que o interessou.

Não teria sido difícil para ele perceber que as múltiplas semelhanças entre a técnica literária e a cinematográfica não precisam ser atribuídas a intenções geniais, mas decorrem simplesmente das possibilidades narrativas dos dois meios de expressão (GOMES, 1981:417).

$\mathrm{Na}$ seqüência do texto, Paulo Emílio fala das relações entre cinema e literatura para a construção da linguagem cinematográfica em função de procedimentos já experimentados pelo romance. Cita Griffith que teria pensado na montagem paralela dos seus filmes a partir da leitura dos romances de Dickens, mas não volta mais à questão levantada por Magalhães Junior.

A menção a essa polêmica envolvendo Paulo Emílio e Magalhães Junior é interessante não só pelo fato de o primeiro ser um dos autores do roteiro que vamos analisar, mas também porque associa o nome e a obra de Machado de Assis ao cinema.

\section{$\mathbf{X X X}$}

Feita a introdução, passemos para a primeira parte do trabalho que levanta os principais pontos do livro Dom Casmurro sugeridos por Roberto Schwarz e J ohn Gledson. 
1. - O livro 


\section{1 - A relação narrador / leitor}

Desde 1900, quando foi lançado, até hoje, Dom Casmurro de Machado de Assis tem sido lido e interpretado de diversas formas. A leitura predominante de Dom Casmurro, logo após a publicação do livro em 1900, é bastante significativa, pois aponta a expectativa de um certo tipo de leitor e de parte da crítica literária em relação à forma como a obra literária deveria retratar a sociedade na qual estava inserida. Ciente dessa questão, Machado de Assis construiu o livro de maneira a propiciar leituras diversas; a partir da identificação ou não do leitor com o narrador.

Para os que buscavam uma leitura de cunho realista ou naturalista: o narrador é o senhor da verdade, vítima de uma mulher traiçoeira que o enganou com o melhor amigo. Para os que buscavam uma leitura apegada ainda às fortes tintas do romantismo: o narrador, também senhor da verdade, torna-se cético e desiludido devido à traição. O amor já não é o mesmo e Machado, um desencantado com a vida.

De uma forma ou outra, parecia haver uma confiança irrestrita no narrador e nos fatos que ele apresenta. Aquilo que ele nos traz é a verdade. Visto que ambas as leituras colocavam no centro da narrativa, como elemento principal da obra, a questão da traição.

Exemplo dessa visão é a crítica de Alfredo Pujol publicada em 1917. O texto revela um ponto de vista interpretativo comum a toda uma época e geração. Pujol diz que Dom Casmurro é um livro cruel e faz a seguinte leitura de Bento e Capitu, e da trama central do livro:

Bento Santiago, alma cândida e boa, submissa e confiante, feita para o sacrifício e para a ternura, ama desde criança sua deliciosa vizinha, 
Capitolina - Capitu, como Ihe chamavam em família. Esta Capitu é uma das mais belas e fortes criações de Machado de Assis. Ela traz o engano e a perfídia nos olhos cheios de sedução e de graça. Dissimulada por índole, a insídia é nela, por assim dizer, instintiva e talvez inconsciente. Bento Santiago, que a mãe queria que fosse padre, consegue escapar ao destino que Ihe preparavam, forma-se em Direito e casa com a companheira de infância. Capitu engana-o com o seu melhor amigo, e Bento Santiago vem a saber que não é seu o filho que presumia do casal. A traição da mulher o torna cético e quase mau. (Apud SCHWARZ, 1997: 10)

Pujol assume como verdadeiro e único o ponto de vista do narrador, identifica-se com ele e condena Capitu sem nenhuma hesitação. Mais que isso, aponta que a traição de Capitu torna Bento Santiago um cético e um homem "quase mau". Atenuação estranha, mas que mostra a convicção do crítico ao aderir ao narrador e ao seu ponto de vista narrativo ${ }^{6}$.

Essa adesão, no entanto, faz parte de uma estratégia criada pelo próprio Machado de Assis que, de forma muito sutil e engenhosa, obriga o leitor a assumir uma posição em relação ao que está sendo narrado, e o faz induzindo-o a aceitar o ponto de vista narrativo. Tal procedimento faz com que o leitor deslize pela narrativa que Dom Casmurro quer fazer prevalecer, embalando-o tal qual o próprio personagem no início da história, quando ouve os versos do vizinho e sente o balanço do trem. Machado cria, como bem define Roberto Schwarz, uma verdadeira armadilha:

O livro tem algo de armadilha, com sua lição crítica incisiva - isso se a cilada for percebida como tal. Desde o início há incongruências, passos obscuros, ênfases desconcertantes, que vão formando um enigma (SCHWARZ, 1997: 09).

\footnotetext{
${ }^{6}$ Essa leitura é defendida por muitos ainda hoje. São bem conhecidas, por exemplo, as crônicas de Otto Lara Resende publicados na Folha de S. Paulo em 1992 e posteriormente editadas no livro "Bom dia para nascer" nas quais o escritor criticava leituras recentes de Dom Casmurro que, segundo ele, viravam o livro ao avesso. 0 título de uma das crônicas é bem emblemático: "Não traiam o Machado".
} 
A armadilha apontada por Schwarz é a construção de uma prosa, para usar o termo que ele próprio usa, envenenada. Machado enreda o leitor na obsessão do personagem narrador. Narrador, possuído pelo desejo de reatar as duas pontas de sua vida, contando depois de velho a sua história, acertando, assim, suas contas com o passado e fazendo vingar a sua interpretação. Há aqui, portanto, um plano duplamente envenenado: o do personagem narrador que escreve o livro e o do escritor, Machado de Assis, ambos com o mesmo propósito: persuadir o leitor.

Mas se a intenção de Dom Casmurro é mais facilmente identificável, se a lição crítica é incisiva, como aponta Schwarz, a intenção de Machado não é tão clara e só pode ser decifrada se nos dermos conta de que estamos diante de um enigma. Mas, para isso, precisamos, voltando a Schwarz, perceber as incongruências, passos obscuros, ênfases desconcertantes; o que exige do leitor um distanciamento do narrado e, acima de tudo, do narrador. Distanciamento difícil para o homem da época, contemporâneo ao livro, por motivos que críticos como Roberto Schwarz e John Gledson têm procurado mostrar.

Schwarz diz que a solução desse enigma terá "custo alto para o espírito conformista, pois deixa mal um dos tipos de elite mais queridos da ideologia brasileira" (1997:09). Afinal, a figura representada por Dom Casmurro é a do proprietário de terras e escravos, ex-seminarista - ou seja, quase padre -, filho devotado à mãe e homem ligado às leis; um bacharel. 
Schwarz credita essa reviravolta na leitura de Dom Casmurro à norte-americana Helen Caldwell no livro O Otelo brasileiro de Machado de Assis que, "por ser mulher? Por ser estrangeira? Por ser talvez protestante?", pôde fazer, em 1960, a leitura do livro que até então ninguém havia feito. Foi ela quem "desmascarou" Dom Casmurro. "Como se para o leitor brasileiro as implicações abjetas de certas formas de autoridade fossem menos visíveis", conclui Schwarz (1997:09).

Para a análise que será empreendida aqui, essa idéia é muito importante: a autoridade do narrador é fundamental para garantir a aceitação de sua história, já que o leitor em tese tende, num primeiro momento, a se identificar com ele ou se submeter a ele.

Em Machado de Assis: Impostura e Realismo, John Gledson analisa esse processo de identificação e destaca que, além da questão da autoridade, o narrador machadiano - ele fala também de Brás Cubas e o Conselheiro Aires - é convincente e simpático, o que funciona como um estratagema intencionalmente concebido "para agradar o leitor, aliciá-lo no sentido de aceitar o ponto de vista do narrador" (2005:08).

Gledson explica que os narradores conseguem isso não pelo uso de argumentos sutis ou pela apresentação convincente dos fatos, mas principalmente pela manipulação dos preconceitos sociais. "Concordamos com eles porque partilhamos suas atitudes", diz Gledson (2005:08). Machado, conclui ele, foi capaz de iludir seu leitor por ter sido capaz de lisonjear seus preconceitos.

Curioso que mesmo quando revelada a habilidade de Machado Assis na construção de Dom Casmurro, do livro e do personagemnarrador; mesmo quando revelado o estratagema da confecção do livro dentro do livro, no qual o narrador seleciona os fatos que lhe convêm e 
impõe seu ponto de vista por ser proprietário e por ter, portanto, o privilégio de escrever a história; mesmo assim, muitos se recusam a aceitar ou crer que se trata de uma armadilha.

E a questão agora não é nem de visibilidade, pois é oferecida a estas pessoas instrumentos para que vejam a questão tal qual Machado a engendrou, mas de aceitação dessa ordem: da impossibilidade de ver ou da apatia que impede que desconfiem e não aceitem a narração, e não só a ela, mas um estado de coisas que de certa forma ainda perdura.

Essa questão colocada por Schwarz, Gledson e detectada primeiramente por Caldwell, é mais importante na pauta do livro que a traição ou não de Capitu. Machado arquiteta toda trama em torno da traição para mascarar a questão do discurso - eis a cilada, a armadilha.

\section{2 - Um registro da sociedade da época}

Tão importante quanto a questão do ponto de vista narrativo e extremamente ligada a ela é a o registro da estrutura social que Machado faz a partir da família de Bentinho, retrato das relações sociais do Brasil no Segundo Reinado.

Só que este é feito de maneira enviesada, é revelado no seu avesso, pois, como lembra John Gledson: a verdadeira natureza das relações sociais no romance está dissimulada. O próprio Bento, analisa Gledson, não as compreende, e Dom Casmurro não pode descrevê-las de modo direto. O fato de o narrador, como já foi dito, ser um representante da elite, simpático às expectativas do leitor, dificulta 
ainda mais a apreensão desse retrato, pois a operação mais fácil do ponto de vista da recepção do livro é o da adesão ao narrador e à história que ele narra, sem nos darmos conta de que existe ali um subtexto a ser decifrado e desvendado.

A suposta traição mascara um ciúme doentio, e mais importante que o ciúme é entender - uso um outro termo de Gledson - as condições que o produzem (2005:12). Vejamos, brevemente, que condições seriam essas.

Machado, com o casal Bento e Capitu, desenvolve, aprimora e embaralha uma questão que já havia sido trabalhada em outros romances seus da primeira fase: a possibilidade de uma mulher ascender socialmente por meio do casamento, rompendo o imobilismo social predominante e sendo aceita junto à elite da época. Capitu, ao contrário de outras personagens machadianas, a mais notável é Estela de Iaiá Garcia, não renuncia a essa possibilidade: acredita nela e a desafia.

Nesse sentido, o muro que separa a casa de D. Glória, mãe de Bentinho, e de Pádua, pai de Capitu, estabelece um limite bastante simbólico e não menos concreto. $O$ preço para quem quer passar para o lado de cá do muro é a renúncia da própria identidade. Para tanto, é preciso aceitar as regras do jogo, aceitar as ordens e caprichos de quem detém o poder, por mais doentios que sejam esses caprichos.

Capitu, ao ousar romper essa fronteira sem aceitar a contrapartida exigida, é capturada ${ }^{7}$ - a coincidência do radical latino talvez não seja tão fortuita - e se torna presa do ciúme e da loucura de Bento, cujo sentimento de posse não distingue objeto. Afinal, ele como

\footnotetext{
${ }^{7}$ Em latim, o verbo captare significa apanhar, agarrar, capturar.
} 
representante mais querido da elite da época tudo pode. Pode até contar a sua história, anos depois, da forma como bem quiser.

Em oposição a Capitu, temos José Dias, personagem que representa o agregado que, entrincheirado entre a classe dominante e os escravos, para sobreviver ou ter maiores benesses se sujeita aos caprichos daqueles que o mantêm. Essa relação de favor e dependência é vital para entender em que condições o ciúme de Bento é produzido, e o que "legitima" o narrador e a narração de Dom Casmurro.

Nesse sentido, Gledson afirma que:

Dom Casmurro não é um romance acerca da maldade pura, sem motivos, nem simplesmente uma série de retratos psicológicos bem delineados; é um romance sobre um grupo de pessoas que age de acordo com a lógica de suas condições sociais e familiares. (2005: 50)

Mas quem mais avança nessa questão é Roberto Schwarz, mostrando quão problemática foi, do ponto de vista estrutural, social e de formação, a aliança paradoxal entre capitalismo e escravidão.

\section{3 - A relação forma e conteúdo}

Todos esses aspectos principais da obra, levantados aqui de maneira breve, se interligam e se fundem na forma engenhosa como Machado concebe o romance. O conteúdo do livro está preso à forma e a forma dita o conteúdo.

Entender o ponto de vista narrativo, o narrador em primeira pessoa, é fundamental para uma melhor compreensão do livro. Esse é o pilar básico do romance. Ele se estrutura e se constrói a partir desse narrador. Friso isso, porque lê-lo de outra forma - ou recontar a história 
sobre outro ponto de vista, como veremos depois - pode nos levar a terrenos movediços, à armadilha da qual já tratamos, a uma outra verdade e a uma outra história.

Silviano Santiago tem uma interessante frase em relação ao que os críticos procuraram na obra. Diz ele: "os críticos estavam interessados em buscar a verdade sobre Capitu, ou a impossibilidade de se ter a verdade sobre Capitu, quando a única verdade a ser buscada no livro é a de Dom Casmurro" (apud GLEDSON 2005: 12).

E o Dom Casmurro citado por Silviano é o narrador que quer, com o romance, atar as duas pontas da vida. Não podemos confundi-lo com Bentinho e nem Bento, que nada mais são do que "personagens" do livro, personagens de Dom Casmurro, frutos da sua verdade, da verdade que ele busca construir e tornar verossímil. Dom Casmurro, ao escrever o livro, constrói Bentinho e Capitu e assim se reconstrói.

O engenho do livro está justamente na possibilidade de ler aquilo que se inscreve, se insere, mesmo que de forma lacunar, na construção do livro dentro do livro. E esse tipo de escritura está relacionado diretamente ao ato da leitura, na forma como o livro se (re)constrói a partir dessa leitura, e da importância do leitor diante do papel designado a ele por Machado de Assis. Idéia, que, como bem lembra Hélio de Seixas Guimarães, "remete à composição do texto como tecido composto de hiatos a serem preenchidos pelo leitor" (2004:27).

O leitor adquire, portanto, um novo papel dentro da obra de Machado, pois joga uma partida de xadrez com o narrador/escritor. E nesse embate, Dom Casmurro é tão senhor da situação que se permite algumas "traições", alguns deslizes. Ele se deleita diante da possibilidade de ser "pego" e da certeza da impunidade decorrente de 
sua autoridade. Lembra um pouco o personagem de Edgar Alan Poe no conto "O Gato Preto", personagem que volta a apontar o lugar em que a esposa está emparedada quando bem poderia ter evitado a prisão, visto que os policiais já não mais suspeitavam dele.

O narrador machadiano brinca com a sua sorte, bate na parede oca da narração para mostrar que existe ali uma outra verdade. Verdade que fica no meio do caminho, entre aquilo que Dom Casmurro narra e as pistas que deixa, e que indicam o que ele pretende com a narração. O livro se revela então pelo que é narrado, o conteúdo, e pela forma como se narra, como se constrói a narração. Há um ir e vir da narração, como a onda que vai e volta, um desdobrar da narração que revela um outro livro ao olhar do leitor mais atento.

Em "Impostura e Realismo", Gledson analisa como Machado mascara os fatos:

Certamente Dom Casmurro não é um romance realista no sentido de que nos apresenta abertamente os fatos, sob forma facilmente assimilável. Apresenta-se com eles, mas temos de ler contra a narrativa para descobri-los e conectá-los por nós mesmos. Na medida em que assim procedermos, descobriremos mais não só acerca do personagem e dos acontecimentos descritos na história, mas também sobre o protagonista de Machado, Bento, o próprio narrador. (2005:14)

Essa afirmação de Gledson é importante porque uma leitura de Dom Casmurro a partir de um viés realista descritivo puro, no qual tudo é dado, revelado de forma "escancarada", é uma leitura parcial da obra, feita na sua superfície. Leitura horizontal que diminui as possibilidades do livro. Possibilidades que se constroem na relação forma e conteúdo e na construção do texto, que se dá no jogo entre narrador/leitor. 
Feita essa breve discussão sobre as questões principais do livro, vejamos como elas estão e se estão no roteiro escrito por Lygia Fagundes Telles e Paulo Emílio Salles Gomes. Antes, porém, é importante conhecer um pouco do trajeto que tornaria o livro em roteiro e depois em um filme e, para isso, conhecer melhor o cineasta, sua filmografia, a que momento histórico do cinema se filia, o período em que filmou Dom Casmurro e a sua relação com Lygia Fagundes Telles e Paulo Emílio Salles Gomes, casal escolhido por ele para a confecção do roteiro. 
2. - A adaptação 


\section{1 - Saraceni e a adaptação de Dom Casmurro}

O filme de Paulo Cesar Saraceni foi feito em 1968 como nome de Capitu. Paulo Cesar Saraceni foi um dos diretores fundadores do Cinema Novo na década de 60. Ele e Glauber Rocha foram os dois primeiros cineastas do futuro movimento a filmar, a saltar da teoria à prática, como diria Glauber num dos primeiros encontros dos dois. No final da década de 50, Glauber fez o curta O Pátio, e Saraceni o curta Caminhos, ambos filmados em $16 \mathrm{~mm}$.

Depois disso, em 1960, Saraceni filma o documentário curto Arraial do Cabo, em $35 \mathrm{~mm}$. O filme ganha sete prêmios no exterior e abre as portas da Europa, tanto para Saraceni como para o Cinema Novo. Começa nessa época um produtivo diálogo entre os cinemanovistas e os cineastas ligados ao Neo-Realismo italiano e à Nouvelle Vague francesa.

Após Arraial do Cabo, Saraceni faz Porto das Caixas, em 1962, com o cinema novo já a todo vapor e vários cineastas filmando seus primeiros longas. O filme, segundo Saraceni, deveria retratar uma questão bem brasileira: a miséria e a posição da mulher na sociedade machista da época, só que antes mesmo da revolução feminista. Essa questão, como veremos mais adiante, também estará presente na adaptação de Dom Casmurro. Aliás, a personagem feminina de Porto das Caixas já tem um pouco de Capitu. Essa relação entre a personagem de Porto das Caixas e a de Dom Casmurro é logo percebida por Paulo Emílio Salles Gomes. "Aquela Bovary que o contexto do subdesenvolvimento torna feroz, aquela fascinante e atroz Capitu suburbana é o primeiro grande personagem feminino nascido no cinema brasileiro" (SARACENI, 1993:148). 
O filme seguinte de Saraceni, Integração Racial, média-metragem de 40 minutos com entrevistas e uma pesquisa sobre a integração racial no Brasil, foi feito em 1964, às vésperas do Golpe Militar, e contou com apoio do Patrimônio Histórico e da Divisão Cultural do Itamarati. O filme, segundo Glauber Rocha, tinha uma estrutura mais poemática do que documentária (SARACENI, 1993: 175).

Depois de Integração Racial, Saraceni voltou a trabalhar o roteiro do seu novo longa, O Desafio. A idéia era fazer "um documentário intimista e subjetivo sobre os efeitos do Golpe nas pessoas, o desânimo e a tentativa desesperada, angustiante, de sair daquela situação de fossa" (SARACENI, 1993: 176).

A idéia de Saraceni era apresentar o filme no Festival Internacional do Rio de Janeiro, em 1965, que traria ao país cineastas e críticos importantes do mundo todo. O filme não foi selecionado para a competição oficial, afinal vivia-se uma época de forte censura, e o general Castelo Branco era convidado do evento. O filme acabou sendo exibido fora de concurso e não fez parte da programação principal, mas ainda assim ganhou prêmios dos críticos internacionais e teve grande repercussão.

Submetido à censura para exibição comercial, o filme demorou cerca de sete meses para ser liberado e teve parte dos seus diálogos cortados. Mas Saraceni conseguiu o que queria: que seu filme repercutisse a situação política e social da época.

Foi durante a preparação de O Desafio que Saraceni teve a idéia de adaptar Dom Casmurro. Na época, Saraceni estava casado com a atriz Isabela e o relacionamento dos dois era doentio, devido às crises 
de ciúmes tanto de Isabela quanto dele. Numa das brigas do casal, Saraceni releu Dom Casmurro e ficou com vontade de adaptá-lo.

Numa das minhas idas e vindas entre o hotel Carlton e Isa, no Jardim de Alá, numa das crises de ciúmes, reli Dom Casmurro de Machado de Assis. Fiquei pensando em filmar esses ciúmes de Bentinho por Capitu (SARACENI, 1993: 209).

Separado de Isabela, Saraceni volta a pensar na adaptação em sua passagem pelo Festival de Berlim de 1966, que organizara uma retrospectiva do cinema novo. Depois de encontrar o amigo Nuno Veloso que morava em Berlim, ele comenta:

Mas, no fundo, esse encontro com Nuno me balançou. É que deu saudade daquela zorra do Brasil - com os milicos e aquela mulher que não me saía do pensamento - eu ainda ia fazer um filme baseado em Machado de Assis, o maior romancista que um país pode desejar ter, e filmar uma obra sua, um clássico, para matar esse ciúme maluco que se apoderara de mim. Os costumes estavam mudando, a revolução sexual a toda... Vou fazer esse filme para mostrar que no Brasil o escritor Machado de Assis anteviu a revolução feminista e sexual, criticando seu tempo atrasado e repressivo (SARACENI, 1993: 217).

A idéia tomaria forma na volta ao Brasil, e Saraceni convidaria no ano seguinte, em 1967, Paulo Emílio Salles Gomes e sua esposa Lygia Fagundes Telles para escrever com ele 0 roteiro. 


\section{2 - O roteiro e o livro}

A adaptação de Dom Casmurro feita pelo casal Paulo Emílio e Lygia ganhou o nome de Capitu e foi publicada em 1993 pela Editora Siciliano, após um longo sumiço do roteiro, nos arquivos da Cinemateca Brasileira. O roteiro tem 36 capítulos e 170 páginas, dez delas com um texto introdutório assinado por Lygia Fagundes Telles.

Em relação ao roteiro, ele é diferente dos roteiros tradicionais que são mais indicativos de ações e falas que recheados de descrições literárias, mas não cabe aqui uma análise do seu aspecto formal, até porque o roteiro, como peça, difere bastante de roteirista para roteirista e não existe, em tese, um roteiro padrão. Analisaremos, sim, sua relação com o livro, que rumos toma e como cada Capítulo se configura.

Ano de 1969. Rua Sabará 400, São Paulo. Acordamos luminosos na manhã daquele mês de novembro, Paulo Emílio e eu: íamos começar afinal a escrever este roteiro (TELLES, 1993:05).

Assim começa o texto, e ele logo de cara nos apresenta um problema: a data. Como em 1969, se o filme foi lançado em 1968? Na verdade, a autora se equivoca, pois outras fontes, inclusive uma biografia de Paulo Emílio ${ }^{8}$, coloca como data do roteiro o ano de 1967.

\footnotetext{
${ }^{8}$ Chequei a data também na biografia de Paulo Emílio, Paulo Emílio no Paraíso assinada por J osé I nácio de Melo Souza e publicada pela Editora Record.
} 
Na seqüência, ela relata as opções do casal em relação ao livro. Tratarei dessas opções depois, quando analisar o roteiro e fizer o cotejo entre livro e roteiro, incluído nos anexos a este trabalho. 0 importante a salientar neste momento é a evidente felicidade que esse trabalho conjunto despertou na escritora, e o quanto ele foi pensado e discutido.

Já tínhamos discutido antes as dificuldades de recriar literariamente Dom Casmurro para uma futura adaptação cinematográfica. Usando de toda a liberdade nessa recriação e sem trair o original - é possível isso? A esperança da liberdade sem traição (TELLES, 1993:05).

O trecho nos mostra, também, aspectos importantes do processo. A escritora fala em recriar literariamente para adaptar, o que seria - e se mostra diferente - adaptar a partir do texto literário em si. A seqüência do parágrafo é ainda mais reveladora e dará margem a uma longa discussão. Fica, por ora, apenas o registro da preocupação de não "trair o original". Interessante notar que a ambigüidade do trair e não trair, "esperança da liberdade sem traição", se aplica tanto à trama quanto à relação literatura e cinema, via adaptação.

Lygia relata, depois, as noites intermináveis de discussão e de trabalho regado a vinho e a café. Diz que viviam na plenitude da ditadura e que já havia feito até algumas anotações para o seu livro, As Meninas. Fala da esperada cassação de Paulo Emílio na Universidade de Brasília, por ser considerado subversivo; conta da admiração deste por dicionários e da felicidade que ele teve ao desdobrar a palavra "combinar", até chegar a "comborço", expressão usada também por Dom Casmurro no livro. 
Na seqüência do texto, ela fala sobre a modinha de Carlos Gomes que, por iniciativa dela, é inserida no roteiro, e a preocupação para ver se esta é anterior ou não à ação do livro. O texto introdutório dá pistas importantes sobre a construção do roteiro e sobre a visão que cada um deles tinha do livro.

Era assim, eu inventava um episódio, ele inventava outro e nesse andar ia crescendo a massa de seqüências, mas não era mesmo uma loucura? Projetar a metamorfose de um quase monólogo meditativo em imagem. A trama tão interiorizada. Submersa. Com um foco narrador revisitando lembranças com tamanha inocência que o leitor pensa logo nas primeiras páginas, mas esse Bentinho é um puro! Sem dúvida, digo eu (TELLES, 1993:07).

O trecho é bastante revelador e algumas opções ficarão mais claras depois no roteiro. A revelação mais importante é a consciência de que o projeto metamorfoseia o livro, ao criar uma "massa de seqüências" a partir de um outro ponto de vista narrativo que não o "quase monólogo meditativo" de Dom Casmurro.

I mportante frisar que a escritora na maioria das vezes se refere a Bentinho sem marcar a distinção entre Dom Casmurro, Bento e Bentinho. Ela também não trabalha ou não menciona a questão da recriação que Dom Casmurro faz de si, enquanto autor da história que reconstituirá a sua vida. O máximo que se aproxima da questão é quando escreve que o foco narrador revisita "lembranças com tamanha inocência que o leitor pensa logo nas primeiras páginas, mas esse Bentinho é um puro!". Lygia parece acreditar em Bento e se chega a ter uma leve suspeita dele, demonstra, nesse texto, que está mais para acreditar mesmo que ele seja inocente. 
Difícil dizer se o casal, ao fazer a sua leitura e adaptação da obra de Machado de Assis, tinha conhecimento do livro de Helen Caldwell, o primeiro a questionar de forma mais sistemática e efetiva o ponto de vista narrativo, e o primeiro a mostrar que Dom Casmurro mascara a narração, escolhendo elementos que visam "vilanizar" Capitu. Como já foi dito, o livro de Caldwell tornou-se um divisor de águas ao sustentar que Capitu é uma vítima da narração envenenada de Dom Casmurro. Porém, o livro de Caldwell foi editado nos Estados Unidos em 1960 e, apesar de circular nos meios acadêmicos no Brasil, só foi traduzido para o português em 2002.

Independente de Lygia e Paulo Emílio terem lido ou não Caldwell, o texto de Lygia deixa claro que pairou no casal a dúvida em relação ao caráter dos personagens. Dúvidas que se insinuam, como diz ela, devido à "fina pele das palavras". O trecho a seguir torna isso evidente:

As ambigüidades do bem. Do mal. As ambigüidades que começamos a sentir sob a fina pele das palavras e que se assemelham ao som de um sutil roc-roc do mais sutil dos roedores roendo o emaranhado dessas entranhas (TELLES, 1993:07).

O registro deixa claro que a escritora tem conhecimento da complexidade do livro na sua engenhosa ambigüidade; mas, em um outro trecho, Lygia parece não perceber que a questão é ainda mais movediça. Ela não se atém ao foco narrativo que possibilita, como lembra Silvano Santiago, apenas uma única verdade, ou seja, a verdade de Dom Casmurro. Ela indaga:

Ficamos, então, sem saber qual é a personagem mais embrulhada, a Capitu? Ou o próprio Bentinho, esse bicho-de-concha que se revela (e se esconde) numa linguagem cristalina? (TELLES, 1993:07). 
Só que não podemos, pela forma como o livro é narrado, criar essa imagem de Capitu porque, na verdade, quem embrulha Capitu - e nos embrulha - é Dom Casmurro. Outro dado curioso desse trecho é a expressão "bicho-de-concha", aqui atribuída a Bento. O mesmo termo é usado por Lúcia Miguel Pereira para se referir a Machado de Assis no texto Machado de Assis: Estudo Crítico e Biográfico. Difícil determinar se o termo vem ou não da leitura do texto de Lúcia, mas a coincidência não parece gratuita e sugere uma identificação entre o escritor Machado de Assis e o narrador-personagem criado por ele...

Recapitulando então alguns pontos importantes do texto introdutório de Lygia, texto que retomaremos ao analisar o roteiro, temos que: o roteiro é uma recriação com a invenção de novos episódios; o roteiro não se prende à ordem dos fatos narrados pelo livro; e o chamado "monólogo meditativo" do livro deixa de existir, pois o narrador no roteiro já não é Dom Casmurro - é a câmera que irá passear pela intimidade do casal, recriando episódios.

Esta opção por um outro ponto de vista narrativo muda totalmente o rumo da história. Foge-se aqui daquilo que é central no livro, ou daquilo que Helen Caldwell identificou em 1960 como fundamental no livro e que depois deu margem aos estudos de Schwarz: o discurso do narrador proprietário que faz valer a sua verdade, usando sua posição privilegiada, procedimento que revela e ajuda a entender a estrutura social da época. Essa questão tão bem explorada por Schwarz não está explorada no roteiro. Na verdade, quem não está no roteiro é o próprio Dom Casmurro.

Também são curiosas e reveladoras as palavras de Lygia em relação a Bento: "tamanha inocência", "Bentinho é um puro". Ela toma partido do personagem masculino, diferente do marido, Paulo Emílio. A 
divisão do casal fica explícita numa passagem do texto, quando Paulo Emílio, segundo a narração de Lygia, pergunta a ela se ela não está ficando com aquele mesmo olhar intenso de Bento, assim que se agravaram as suspeitas. Em outro momento, ela diz que Paulo afirma que ela estava por demais impregnada das desconfianças do narrador.

Respondi com um desafio, mas é possível mergulhar nesse texto e não tomar partido? Continuar neutro? Ele fez aquele ar bíblico de quem paira sobre todas as coisas e disse se esforçar em ser apenas o intérprete onisciente, o que testemunha e registra, mas não interfere (TELLES, 1993:09).

Mais à frente, no texto, ela volta a essa preocupação em não tomar partido, mas se entrega.

Para não tomar partido, nos esgotamos nas conversas na fase das conversações (sic). Era preciso, sim, nos limparmos completamente da paixão dos julgamentos para tentar um trabalho com equilíbrio. E isenção. Não éramos juízes, mas dois leitores escritores com a tarefa de relatar (e dilatar) o tempo desse Bentinho ofuscado pelo ciúme. Eu concordava. Mas na minha natureza mais profunda, já estava envolvida pelo cipoal das inquietações do ex-seminarista, semente do Dom Casmurro (TELLES, 1993: 9).

Quatro coisas nesse trecho são importantes: a primeira é a traição, o motor do roteiro; outra é o termo dilatação - o roteiro de fato aumenta os episódios que ocorrem após o casamento de Bento e Capitu; a terceira é a visão dela, declaradamente simpática a Bento; e a quarta, e mais importante, é que apesar de sugerir ter consciência de que o ex-seminarista, Bentinho, não é exatamente o mesmo que Dom Casmurro, já que um seria semente do outro, essa idéia não está no roteiro.

Existe um outro trecho da introdução no qual a escritora deixa clara a sua postura pró-Bento. Fato curioso é que neste trecho ela 
revela que em sua primeira leitura do livro, quando era "uma inexperiente mocinha que estudava direito", ela viu Capitu como vítima, mas depois, na releitura, ela teve outra percepção. Nessa nova leitura, ela "começava a ver melhor essa manipuladora desde a meninice, ah! sim, amante de Escobar e o menino era filho dele" (TELLES, 1993: 10).

Paulo Emílio também assumia em determinados momentos uma posição ambígua em relação à história, e creditava a traição à atitude de Bento. O comportamento sinuoso de Capitu, diz ele, segundo relato dela, pode ser:

um simples reflexo dos seus pressentimentos, era uma sensível. Uma perceptiva. Intuiu a tempestade que já se armava porque conhecia o mecanismo do marido com suas antigas e dementadas crises (TELLES, 1993: 10).

O olhar do casal é sempre dividido e cheio de dúvidas. Paulo Emílio, porém, diz que "pode ser"; já a escritora tende a aderir mais a Bento e olhar de maneira mais desconfiada para ele apenas quando pára e analisa frases como: "Apesar de tudo, jantei bem e fui ao teatro". Lygia acredita e deixa de acreditar em Bento Santiago, fazendo no seu texto introdutório um movimento pendular que transparece essa postura oscilante.

Em outro momento do texto, ela fala que Bentinho é um tipo neurótico desde a mocidade e que a coitada da Capitu devia andar apavorada com aquele "marido parafuso" e suas crises de ciúme, recuperando aquela sua primeira leitura, quando absolveu Capitu. Paulo Emílio, diante da atitude da mulher, pede que ela não descarte a hipótese da traição. O que a deixa, de novo, na dúvida. 
Toda essas idas e vindas do texto e da relação de Lygia com Capitu e Bento acabam sendo fechadas com um trecho que resume as opções e dilemas de Lygia e Paulo Emílio:

(...) o trabalho estava chegando ao fim. E sem vestígios das passadas preocupações, vigorava o foco-narrador mas sem a nossa cumplicidade. Não havia nem culpados nem inocentes mas apenas aquele espaço e tempo (Rio de Janeiro, ano de 1865) fluindo na ardente narrativa do moço Bentinho antes de se transformar no pacato Dom Casmurro da maturidade anunciada. A verdade? Ora, a verdade era aquele mar, o misterioso mar com suas ondas espumejantes arrebentando nas pedras (TELLES, 1993: 13).

De uma forma ou de outra, acreditando mais em Bento ou em Capitu, o que temos é uma leitura focada num aspecto do livro que, como já vimos, não é o mais importante, pois a hipótese da traição mascara algo maior. E, na impossibilidade de se chegar à verdade, a própria Lygia assume que vigora o foco narrador sem a cumplicidade do casal, sem inocentes ou culpados. Leitura ou recriação que coloca a obra de Machado de Assis num outro caminho, não mais revisitado pelo personagem na sua velhice, e sim, reconstruído, sob o ponto de vista de um narrador onisciente e mais neutro, a câmera, e focado num espaço e tempo delimitado, do casamento de Capitu e Bento aos momentos que sucedem o enterro de Escobar, ou seja, antes de Bento se transformar em Dom Casmurro. Parece estranho, mas é uma adaptação de Dom Casmurro sem Dom Casmurro. Essa é a idéia que esmiuçaremos agora, comparando o roteiro ao livro. 
3 - A análise 


\section{1 - Elementos para análise}

Feita a discussão do texto de Lygia Fagundes Telles que introduz o roteiro, vejamos como se relacionam livro e roteiro. Para efeito de comparação, vamos detalhar o roteiro do filme, cotejando-o com os episódios do livro e apontando acréscimos quando existirem.

Mas antes de iniciar efetivamente a comparação é preciso estabelecer algumas distinções de fundo teórico, bem como metodológico ou instrumental.

A primeira distinção importante a ser feita é entre cena e narração sumária, dois modos básicos de narração segundo Norman Friedman, no texto, O Ponto de Vista na Ficção (Revista USP no 53, 2002). Sumário narrativo seria a exposição generalizada de uma série de eventos, abrangendo um certo período de tempo e uma variedade de locais. Cena implicaria na apresentação de detalhes concretos e específicos dentro de uma estrutura bem determinada de tempo e lugar.

Esta questão tem, como lembra Ismail Xavier, efeito enorme no "problema da adaptação" que é o modo como ele se refere ao processo de adaptação de uma obra literária para o cinema (XAVIER in PELLEGRINI, 2003:72). Ele lembra que a cena é uma "ocorrência freqüente nos romances, às vezes, generosa e cheia de detalhes", caso de Dostoievski "em seus lances mais dramáticos" e é "bem mais precisa, mais concisa e mais discreta em Flaubert".

Em se tratando de Machado, a questão é ainda mais complexa, porque se temos algumas cenas, temos, predominantemente, o sumário narrativo apoiado num outro tipo de narração - se é que assim podemos 
chamá-lo -, que é a digressão, usada como uma espécie de comentário das ações e mesmo das cenas.

Além disso, temos em Machado um narrador intruso que se comunica diretamente com o leitor e até o provoca. Este é outro procedimento complicado ou problemático para a adaptação, visto que o cinema, sobretudo o cinema clássico, privilegia as regras de transparência e ilusionismo, ou seja, a história deve ocorrer sem interferência, sem que o espectador se dê conta da narração, pois esta precisa evoluir por si mesma, como se fosse autônoma (XAVIER in PELLEGRINI, 2003:69/70).

Mas, voltando à cena e ao sumário narrativo - e deixando de lado a discussão do narrador intruso, o que precisamos ter em mente é como esses modos básicos de narração são usados no roteiro/filme para estabelecer uma relação com a trama do livro, aquilo que no processo de adaptação podemos chamar de equivalentes formais, procedimentos fílmicos que traduzirão, ou procurarão traduzir, aquilo que está no livro: seja na articulação do ponto de vista narrativo, seja por meio de figuras de linguagens usadas para construir o sentido da trama, seja pela forma como os períodos e capítulos do livro estão organizados etc.

A segunda questão, premente nesse momento, e mais do ponto de vista metodológico do que teórico, é imaginar como poderemos fazer o cotejo entre roteiro e livro de maneira mais sistemática. Usarei aqui o modelo teórico proposto por J oão Batista de Brito no seu livro Literatura no Cinema, a partir do conceito de Francis Vannoye. Vannoye definiu como instrumento para este tipo de análise, passagem do livro para o filme, no nosso caso apenas o roteiro, dois tipos de operação: redução e adição. Brito adicionou a estas duas outras operações: o deslocamento e 
transformação, sendo que a transformação pode se subdividir num processo de simplificação ou de ampliação (BRITO, 2006:11).

Mas, antes de usá-las, é necessário explicar melhor esses termos.

Redução seria o termo para designar a operação que indica que elementos que estão presentes no texto literário foram excluídos da adaptação.

Adição seria o processo inverso, elementos que aparecem na adaptação, mas não estão no livro.

O deslocamento indicaria o processo de mudança da ordem cronológica ou espacial de elementos do livro.

A transformação, propriamente dita, é o processo pelo qual os elementos que estão no livro e na adaptação possuem significados equivalentes, mas têm configurações diferentes. Um processo similar ao da tradução, buscando equivalentes formais e semânticos.

A simplificação e a ampliação estariam relacionadas a estas transformações. A simplificação seria uma transformação que consistiu em diminuir a dimensão de um elemento que, no romance, era maior. $\mathrm{E}$ ampliação, transformação que consistiu em aumentar a dimensão de um ou mais elementos do romance. (BRITO, 2006:11/20)

Este modelo, é obvio, não resolverá todos os problemas, mas encaminha bem as questões a serem discutidas no cotejo entre o roteiro e o livro no que tange à história narrada e seus episódios, à construção dos personagens dessa história e, principalmente, na forma como ela é 
narrada, incluindo aí o ponto de vista narrativo e os procedimentos narrativos.

Comecemos pela história narrada no livro e os capítulos que não estão no roteiro, fazendo uma breve abordagem do conteúdo e da forma.

\section{2 - O livro que não está diretamente no roteiro}

Dom Casmurro tem 148 capítulos curtos, uma narrativa bem fragmentada. Cerca de dois terços do livro, a primeira e a segunda parte dele, se assim o dividirmos, não estão de forma direta no roteiro. A primeira parte compreenderia do episódio da denúncia de José Dias até a ida de Bentinho ao seminário, os primeiros 50 capítulos do livro. Já a segunda parte, do seminário até o casamento, do cap. L ao C. O roteiro centra-se, portanto, na última parte do livro, que vai do casamento, no cap. C, até a separação.

Vejamos num primeiro momento essa parte do livro que não está diretamente no roteiro, ou seja, os 100 capítulos iniciais, cujos eventos, quando abordados, o são por citação ou um ou outro flashback.

A primeira parte de Dom Casmurro se detém na construção do livro dentro do livro, caps. I e II, sobretudo, e na infância de Bentinho, na qual a grande questão é a ida de Bentinho ao seminário. Nos dois primeiros capítulos, Bento explica como ganhou o apelido Dom Casmurro que dá nome ao livro - na cena do trem na qual Bento não dá ouvidos às poesias de um conhecido. No capítulo seguinte, o narrador explica a razão do livro, diz que quer escrever para atar as duas pontas 
da vida. Os dois capítulos iniciais são fundamentais porque servem como um prólogo, só que dentro do livro, embaralhando ainda mais a relação escritor/autor/narrador também presente em Memórias póstumas de Brás Cubas. Importante também porque vão configurar o ponto de vista narrativo do livro, o tempo a partir do qual a história será (re)construída e do qual serão (re)apresentados personagens e eventos.

No capítulo seguinte, o narrador traz uma cena fundamental para a história, que é a denúncia de José Dias a D. Glória, de que Bentinho estaria se enamorando de Capitu e que a ida dele ao seminário, conforme promessa dela, seria uma saída para essa perigosa amizade. Bentinho ouve tudo e quem nos relata é Dom Casmurro que com muita habilidade irá nos apresentar de forma sumária os demais personagens que habitam a casa. A cena se passa em 1857.

A partir desse conflito - a denúncia e a iminente ida ao seminário se desenvolvem os capítulos seguintes. Dom Casmurro passa então a alternar capítulos que irão apresentar José Dias (cap. V), tio Cosme (cap. VI), D. Glória (cap. VII), Pádua (cap. XVI), prima Justina (cap. XXI) e capítulos que rememoram a promessa de D. Glória, como Bentinho reagiu a ela, como planejava escapar ao seminário para poder continuar ao lado de Capitu, e nos quais Dom Casmurro constrói a relação de Bentinho e Capitu, fornecendo as primeiras características da personagem feminina (caps. IV, XI, XII, XII, XIV e XV).

Intercalados a estes capítulos e a esse nó, temos capítulos que costuram a narrativa, expondo as intenções do narrador, por meio de digressões e comentários. Nos caps. VIII, IX e X, por exemplo, Casmurro lança a metáfora da vida como uma ópera feita numa parceria entre Deus e Satanás, um misto de parábola com teoria na qual a 
seriedade ou jocosidade da questão nunca fica muito clara. Esse expediente será usado em todo livro. E sobre este recurso, Robert Stam, ao tratar da relação literatura e cinema, e dos filmes e livros que procuram ser mais ou menos ilusionistas, no sentido de acobertar o dispositivo da narração, faz um comentário esclarecedor:

Para a maioria dos escritores, as metáforas funcionam como condutores "transparentes" de informações ou impressões. Já Machado de Assis sempre procura expô-las e comentá-las. Em vez de nos oferecer metáforas como um produto acabado para consumo, revela-as no processo de elaboração. Certa vez, após propor uma metáfora, logo em seguida julga-a impertinente. "A comparação não presta", diz ele (STAM, 1981:69).

Stam, ao analisar procedimentos anti-ilusionistas desse tipo, afirma que nessas ocasiões a escrita parece estar sendo feita diante dos próprios olhos do leitor, com a ajuda do mesmo (1981:70). Esse expediente formal acaba construindo um elo de confiança entre o narrador e o leitor. No cap. X, Casmurro chama o leitor de amigo, cativa-o. Curioso que, na mesma linha, ele dispara que a "verossimilhança é muita vez toda a verdade", o que nos remete à já citada questão do narrador que dá pistas e brinca diante da possibilidade de ser desmascarado.

Voltando à estrutura narrativa do livro, numa tentativa de dispor alguns acontecimentos ou eventos em linha reta, diante da delação do amor proibido e da promessa da mãe de mandá-lo ao seminário, Bentinho planeja como contar a Capitu o ocorrido e, após isso, juntos planejam uma estratégia para tentar "conquistar" José Dias, fazendo com que este mude de lado e demova D. Glória da promessa (caps. XVIII a XXIV). O cap. XXV traz a cena do encontro de Bentinho e José Dias, no qual o agregado alerta Bentinho para os olhos de cigana 
oblíqua de Capitu. Dom Casmurro descreve o encontro e fornece dados importantes sobre o personagem José Dias, sua relação com a família de Bentinho e de Capitu.

A partir do encontro, o livro se atém à possibilidade de José Dias interceder junto a D. Glória e evitar a ida de Bentinho ao seminário, com os desdobramentos do encontro e eventos que antecedem essa ida de Bentinho ao seminário. Entre esses eventos, destaque para o sonho acordado de Bentinho, imaginando que o Imperador pudesse interferir a seu favor (cap. XXIX); a cena da procissão do Santíssimo, na qual fica evidente a inferioridade social de Pádua (cap. $X X X$ ); primeiro beijo de Bentinho e Capitu (cap. XXXIII); a visita do Padre Cabral e a oscilação de Bentinho entre o desejo por Capitu e o seminário (caps. XXXV a XL); a entrevista de Bentinho e D. Glória na qual ele cogita confessar à mãe o seu amor por Capitu, mas acaba por se submeter ainda mais ao desejo e poder da mãe (caps. XLI e XLII) e, na seqüência, a reação de Capitu à entrevista de Bentinho com D. Glória, indagando-o se ele tem medo da mãe e a perguntando quem ele escolheria se tivesse que optar entre ela e a mãe? (caps. XLII a L)

Da denúncia à ida de Bentinho ao seminário, ou seja, nos 50 primeiros capítulos do livro, o personagem de José Dias, o agregado, tem grande destaque na trama. É ele quem percebe e quem aponta, tanto para D. Glória como para Bentinho, o quanto a relação entre os adolescentes é indesejada do ponto de vista social e é ele também quem sugere existir um ar malicioso em Capitu. Malícia que Dom Casmurro também insinua ao tratar das "curiosidades" de Capitu (cap. $X X X I)$.

Do ponto de vista formal, fica evidente nesse primeiro terço do livro que os capítulos são compostos a partir de um modo de narração 
peculiar que seria o da rememoração da cena, acrescido de comentários e digressões do narrador em primeira pessoa. Todos os eventos são repassados ao leitor por este narrador e "contaminados", mesmo que o leitor não se dê conta, pela visão que o narrador tem da história e do seu desfecho. Mas isso é feito com sutileza ímpar, ainda mais nesse primeiro momento do livro.

A partir do cap. L, o livro concentra-se na vida de Bentinho no seminário, e dois importantes personagens entram em cena: Escobar, colega de seminário, no cap. LVI, e o ciúme de Bentinho por Capitu, cap. LXII, intitulado "Uma ponta de Iago". No capítulo em que surge Escobar, um procedimento estilístico nos ajuda a entender o que foi dito no parágrafo anterior:

Eu ainda não era Casmurro, nem Dom Casmurro; o receio é que me tolhia a franqueza, mas como as portas não tinham chaves nem fechaduras, bastava empurrá-las, e Escobar empurrou-as e entrou. Cá o achei dentro, cá ficou, até que... (cap. LVI)

A reticência final, ou aposiopese, como a figura de linguagem é conhecida, exemplifica esse comentário "contaminado" da cena. O "até que..." remete ao final da história, e, além de criar um suspense em relação a eventos que acontecerão e a participação do recém-chegado Escobar a esses eventos, faz com que fiquemos mais atentos a esse personagem que parece ter "invadido" a casa/história/vida de Bentinho diante da fraqueza e ingenuidade do mesmo. Ou seja, em nosso primeiro contato com Escobar, Dom Casmurro logo põe Bentinho como vítima e deixa uma suspeita quanto a Escobar: um "intruso", ou um invasor. 
O mesmo procedimento ocorre no cap. XXXI, quando Dom Casmurro fala das curiosidades de Capitu. "Capitu era Capitu, isto é, uma criatura mui particular, mais mulher do que eu era homem", escreve Dom Casmurro, para logo depois deixar clara a intenção da frase. "Se ainda o não disse, aí fica. Se disse, fica também. Há conceitos que se devem incutir na alma do leitor, à força de repetição".

Tão importante quanto o surgimento de Escobar é o aparecimento do ciúme despertado por José Dias ao responder à pergunta de Bentinho sobre Capitu. Diz ele que ela andava alegre como sempre e que não sossegaria enquanto "não pegasse algum peralta da vizinhança". Nasce aí o ciúme de Bentinho, próximo ao aparecimento de Escobar. E num capítulo seguinte, LXIII, Bentinho sonharia com Capitu à janela com o suposto peralta que, na verdade, ou melhor, no sonho, era um moço que levava ao pai de Capitu o resultado da loteria. Interessante notar que o capítulo tem o sugestivo título "Metades de um sonho", que pode se referir tanto ao fato de Bentinho ter despertado do sonho real como ao ciúme ao qual Bentinho se prenderá a partir de agora.

Os cap. LXV e LXVI também trazem informações importantes seja do ponto de vista da construção formal do livro como da sua trama. No cap. LXV, Bentinho em visita à família fala de Escobar a Capitu e diz a ela que tem vontade de contar a ele sobre o amor dos dois. Capitu pede que não. É a primeira configuração do trio, sugerida por ele e negada por ela. No capítulo seguinte, Dom Casmurro conta que Capitu estava cada dia mais apegada a D. Glória. A pergunta que surge e cuja resposta não temos é: como ele soube disso e pôde reproduzir com riqueza de detalhes, reproduzindo até diálogos, se ele estava no seminário nesse período? 
Nos capítulos seguintes temos como eventos importantes o adoecimento de D. Glória (cap. LXVII) e o pensamento de Bentinho que relaciona a possível morte dela ao fim da promessa, e em conseqüência, sua saída do seminário. Fato que irá enchê-lo de remorso no capítulo seguinte, mas que ele usará para convencer o leitor de que diz no livro toda a verdade: "Ora, só há um modo de escrever a própria essência, é contá-la toda, o bem e o mal", diz Dom Casmurro, citando Montaigne.

Outro evento importante ocorre no cap. LXXI, quando Escobar visita Bentinho e família e, na saída, no momento em que os dois se despedem, Capitu os observa da janela. Interessante rememorar como a estrutura da cena é parecida ao sonho de Bentinho, mas os papéis estão invertidos. No capítulo seguinte, Dom Casmurro, ao falar sobre a ordem dos capítulos no romance - o título do capítulo é "Reforma dramática" - , faz uma digressão sobre o que aconteceria se o desfecho de Otelo viesse no início do texto e não no final.

Dom Casmurro retoma essa digressão formal e essa relação do romance com a dramaturgia no capítulo seguinte, falando do contraregra que determina a entrada dos personagens no drama. É clara a relação entre a cena que Capitu observa os dois na janela, com a citação de Otelo, e essa digressão a respeito da entrada dos personagens em cena, até porque o evento seguinte é o de Bentinho embaixo da janela e Capitu na janela no momento que passa um dândi. "Ora, o dandy do cavalo baio não passou como os outros; era a trombeta do juízo final e soou a tempo; assim faz o Destino, que é o seu próprio contra-regra", escreveu Dom Casmurro que depois diz que esse foi o segundo dente de ciúme que o mordeu.

O ciúme será também o motor dos capítulos seguintes: Bentinho liga a figura do dândi ao "peralta" da vizinhança que José Dias tinha 
mencionado (cap. LXXIV), pensa em matar Capitu (cap. LXXV), confessa ciúme a Capitu, dizendo que é a primeira e última vez que suspeitará dela (cap. LXXVI). No cap. LXXVIII, Bentinho volta ao seminário e conta a Escobar que não tem vocação religiosa e que tem uma paixão de infância: Capitu. Escobar diz que não tem vocação religiosa também, que sua vocação é o comércio. Tornam-se então confidentes. Os eventos seguintes vão mostrar a proximidade de D. Glória e Capitu, de Capitu e Sancha, a semelhança física de Capitu com a mãe de Sancha um ruído importante na narrativa em se tratando da questão da semelhança depois do filho deles com Escobar -, o desejo de Bentinho de estar mais próximo a Capitu, a proximidade de Bentinho e Escobar.

A partir do cap. XCV, o romance ganha um novo contorno com a saída de Bentinho do seminário, comunicada por José Dias a Bentinho. No cap. XCVIII, chamado "Cinco anos", temos uma narração sumária da saída de Bentinho do seminário até sua formação como bacharel em Direito, ou seja, dos 18 aos 22 anos. O capítulo narra também que Sancha e Escobar se casaram e que Bentinho está cada vez mais parecido com o pai (cap. XCIX).

Esses 99 capítulos, cujos episódios principais estão resumidos aqui, não estão no roteiro de Lygia e Paulo Emílio a não ser em raros flashbacks, como a cena da inscrição no muro feita por Capitu, entre outras que veremos a seguir, quando analisaremos os capítulos do livro que estão descritos no roteiro. 


\section{3 - O livro que está no roteiro}

O roteiro de Lygia Fagundes Telles e Paulo Emílio Salles Gomes para o filme de Saraceni coloca como centro da narrativa o ano de 1865, ou seja, ano do casamento de Bento e Capitu, e segue deste ano até a separação do casal. Salvo alguns flashbacks, o roteiro segue de forma linear pelos episódios dessa última parte do livro.

Se no livro, o ponto de irradiação do foco narrativo parte de Dom Casmurro, Bento velho, que num longo flashback reconstrói a sua vida, explicando o título e o porquê do livro, para então regressar a 1857 quando J osé Dias denuncia à D. Glória o namoro de Bentinho e Capitu e aí sim, seguir de maneira mais linear a rememoração da história de Bento e Capitu, no roteiro, o ponto central é o casamento, e é dele, presente da adaptação, que parte todo o ponto de vista narrativo.

Essa distinção do ponto de irradiação do foco narrativo é que justificara o título deste trabalho, mas antes de analisar as principais diferenças estruturais entre livro e roteiro e como eles se relacionam aos capítulos do livro é importante descrever como o roteiro é construído.

O roteiro começa no quarto da casa da Barra da Tijuca. A data é março de 1865, logo após o casamento. Com os dois bem próximos aparece uma legenda sobre a imagem do casal. A legenda tem os dizeres do versículo da primeira epístola de S. Pedro:

"As mulheres sejam sujeitas a seus maridos... Não seja o adorno delas o enfeite dos cabelos riçados ou as rendas de ouro, mas o homem que está 
escondido no coração. Do mesmo modo, vós, maridos, coabitai com elas, tratando-as com honra, como a vasos mais fracos e herdeiros convosco da graça da vida...".

Em relação ao livro, duas coisas devem ser ditas. A primeira é que esses dizeres também estão no livro, no cap. $\mathrm{Cl}$, e tem um motivo, visto que, no final do mesmo capítulo do livro, Dom Casmurro comenta e dá uma nova elaboração à epístola.

Ao cabo, pode ser que tudo fosse um sonho; nada mais natural a um exseminarista que ouvir por toda a parte latim e Escritura. É verdade que Capitu, que não sabia Escritura nem latim, decorou algumas palavras, como estas, por exemplo: "Sentei-me à sombra daquele que tanto havia desejado". Quanto às de S. Pedro, disse-me no dia seguinte que estava por tudo, que eu era a única renda e o único enfeite que jamais poria em si. Ao que eu repliquei que a minha esposa teria sempre as mais finas rendas deste mundo. (Cap. $\mathrm{Cl}$ )

Existe aqui uma inversão do credo cristão, colocando a questão material à frente da religiosa, mas o comentário do narrador do livro não está no roteiro, até porque seria difícil retratá-lo no futuro filme sem a figura de Dom Casmurro. Ou seja, a epístola, cujo sentido é invertido depois - tal qual faz Bento com a cena de Otelo -, tem, no roteiro, uma outra significação, reforçando a imagem do casamento, e rendimento muito diferente do livro no qual essa celebração, se assim podemos dizer, é sutilmente invertida e embaralhada.

Depois da legenda, o roteiro traz a cena de Capitu com a roupa da cerimônia, sentada na cama, e a voz em off de Bento diz: "Serás feliz, Bentinho. Serás feliz". Capitu responde: "É claro que vai ser feliz". Ele retruca: "Você também ouviu?". Ela diz: "Ouviu o quê?". Bento: "Uma voz que dizia que eu serei feliz". Ela responde: "Mas, se foi você mesmo que disse". 
Existe nesse primeiro diálogo uma alteração importante em relação ao livro. Usando o termo de Vannoye / Brito, temos um deslocamento, pois esse episódio no livro não se dá nesse momento, e sim num momento anterior, quando Bentinho chega do seminário e eles ainda não estão casados, e nem há menção da hipótese do casamento. Outra mudança ocorre em relação aos personagens envolvidos no diálogo. Quem ouve no livro a voz de Bento é José Dias (Cap. C), e não Capitu.

Essa cena inicial, com as duas alterações apontadas, é bastante indicadora do que a adaptação virá a ser. O versículo ganha muito destaque e coloca o casamento como a base do roteiro. Da mesma forma, a primeira aparição de Bento é bastante significativa, pois ao externar em voz alta aquilo que imagina estar pensando, ele evidencia um indício da sua "loucura" ou "tormento". Por outro lado, a mudança entre os protagonistas do diálogo, Capitu no lugar de José Dias, mostra que o personagem do agregado terá um destaque muito menor na adaptação, pois esta será centrado no casamento, na família de Bento Santiago e Capitu, e não na família de D. Glória e nas relações sociais que ali se estabelecem, tendo como figura de destaque o agregado.

O segundo capítulo do roteiro - que, como já foi dito, não segue a estrutura típica de um roteiro, dividido em seqüências e cenas, indicando o espaço, o momento da ação, se a ação ocorre de dia ou de noite, e se o espaço é externo ou interno - traz Bento e Capitu no jardim da casa na Barra da Tijuca. O jardim descrito é cheio de árvores e animais, e a cena narrada literariamente é bem romântica, com Bento colocando uma rosa no coque da esposa. No jardim, Bento diz que queria ser poeta, diz que D. Glória em vez de fazer a promessa para ele 
ser padre deveria ter feito promessa para ele ser um poeta. Capitu indaga se haveria um seminário para poetas e diz que, se fosse essa a promessa, teriam se casado há mais tempo. Ainda no jardim, Bento ouve um bem-te-vi e o imita.

Todos esses episódios não têm nenhuma correlação com o livro. Apresentam um Bento com aspiração artística, e romântico, muito diferente do personagem do livro. Devem-se considerar aqui também duas características bem marcantes do roteiro: a presença bem mais ostensiva da paisagem no roteiro do que no livro, o que se justifica porque num filme o espaço físico é mais palpável, desenvolveremos essa questão mais adiante e também a ênfase que o roteiro dá à questão da imitação, algo que será ainda mais explorado quando Ezequiel estiver em cena.

Voltando ao segundo capítulo do roteiro, o casal observa a beleza do jardim, o próprio Éden, quando vêem dois escravos carregando um cesto - a presença de escravos também é mais marcante no roteiro do que no livro -, depois observa um coqueiro que os faz lembrar do coqueiro velho no quintal de Matacavalos. Vêem então uma cobrinha d’água, e Capitu a associa a José Dias. Bento diz que sim. Diz ele:

Aquele mesmo jeito de aparecer e sumir tão silenciosamente depois de armar suas conspirações, é claro. Ah, Capitu, o ódio que tive dele naquela tarde, quando percebi seu jogo para nos separar. E mamãe tão inocente, aprovando.

Capitu responde que não sabe de que tarde Bento está falando. Bento diz que Capitu não pode ter esquecido, que conversaram dias sobre isso e que ficaram aflitos naquele momento. 
O esquecimento de Capitu também é bastante pontuado no roteiro para estabelecer relação com o livro e mostrar um certo desinteresse e desapego por parte dela. No livro, no cap. CX, Capitu se esquece da toada do vendedor de cocadas, algo que havia sido marcante na infância dela e de Bentinho.

Todo esse capítulo do roteiro, com recordações dos tempos vividos, é uma distensão de um trecho do livro no qual Dom Casmurro fala que naquela semana ele e Capitu recordaram episódios da infância. O sumário narrativo do cap. Cll do livro diz o seguinte:

De quando em quando, tornávamos ao passado e divertíamo-nos em relembrar as nossas tristezas e calamidades, mas isso mesmo era um modo de não sairmos de nós. Assim vivemos novamente a nossa longa espera de namorados, os anos da adolescência, a denúncia que está nos primeiros capítulos, e ríamos de José Dias que conspirou a nossa desunião, e acabou festejando o nosso consórcio.

Esse sumário narrativo do livro ganha enorme importância e desenvolvimento no roteiro, pois é a partir dele que é inserido o episódio da denúncia do amor de Bentinho por Capitu feito por José Dias a D. Glória. Desta forma, o personagem de José Dias ganha algum peso, no roteiro, mesmo que mínimo, e um importante conflito do livro - ou seja, a denúncia - aparece no roteiro, mesmo tendo uma importância infinitamente menor, quase que acessória.

O episódio da denúncia estará no capítulo seguinte do roteiro, o capítulo 3, e ocorrerá por meio de um flashback, recurso que voltará a ser usado no roteiro. O episódio, no entanto, é diferente do descrito no livro no cap. III. A principal diferença é que no roteiro não temos os personagens tio Cosme e prima Justina, que estão, nesta cena, no livro. Na adaptação estão, nesta cena, apenas José Dias e D. Glória. Já o 
diálogo, conserva semelhanças com o do livro, mas há uma troca de termos. O roteiro usa a expressão "bom partido" ao se referir a Bentinho. No livro, J osé Dias fala que D. Glória talvez não creia em "tais cálculos". Ressalto essa troca de termos, porque a adaptação trabalhará de forma mais enfática a hipótese de Capitu ter dado um golpe, questão que voltará a ser explorada no roteiro e de maneira mais incisiva em diálogos entre Sancha e Capitu, que não existem no livro.

Fechando esse flashback do Capítulo 3 do roteiro, os autores indicam que a câmera deve recuar e então ouve-se Bentinho criança na varanda, indignado, rechaçando uma fala de José Dias, na qual o agregado fala dos altos destinos da Igreja, cita que um bispo presidiu a constituinte e que Padre Feijó governou o Império. Bentinho diz que vai mostrar a José Dias com quem ele se meteu e o chama de parasita mentiroso. No livro, quem rechaça essa fala é tio Cosme e não Bentinho e, em nenhum momento, o garoto fala de José Dias nesses termos.

O capítulo quatro do roteiro retoma o presente da narração, ou seja, o casamento, com os dois passeando no jardim. Capitu e Bento falam de José Dias, citam sua origem, sua relação com a homeopatia e voltam a relacioná-lo com a cobrinha verde. Bento chama José Dias de ladino e diz que foi ele quem the deu o alarme de que o que ele sentia por Capitu era amor. Capitu pega uma maçã "verdolenga" e diz que ela já sabia há muito tempo: "antes mesmo daquele dia em que escreveu o nome deles no muro". A fala é a deixa para um outro flashback. Mas, antes, é preciso ressaltar que a cena do roteiro acaba criando a própria imagem do "paraíso": o casal no Jardim do Éden, a cobra, a maçã...

O segundo flashback do roteiro, no capítulo 5, recupera o episódio no qual Capitu escreve no muro: caps. XIII, XIV e XV do livro. No livro, 
Bentinho aparece para dar a notícia do seminário, mas hesita e flagra Capitu rabiscando o nome dos dois no muro. No roteiro, Bento nem cita a questão do seminário.

Vale destacar que o muro e o seminário, peças fundamentais para orientar a leitura e mostrar como a hipótese da união denunciada por José Dias é mal vista - o muro como metáfora para o apartamento dos dois em mundo diferentes, e o seminário como destino interessante para se evitar a união -, não têm no roteiro o mesmo tratamento, dada a inversão da ordem cronológica dos episódios e a mudança do eixo central da narrativa, agora relacionada ao ciúme que tomara corpo, sobretudo, após o casamento, e não à questão das classes e do papel do agregado para manter a ordem das coisas. Dois dos temas centrais no livro são tratados de maneira mais superficial no roteiro, mas deixemos para explorar essas questões de forma mais detalhada após a descrição de todo os capítulos do roteiro.

Existem ainda outras mudanças nesse quinto capítulo do roteiro em relação ao livro. Pádua é descrito no roteiro como um homem pobremente vestido e "com andar vacilante", apoiado numa grossa bengala, com um pé calçado e outro no chinelo de lã, que fala em tom lamentoso e que sofre e reclama de dores causadas pela gota e artrite. O roteiro menciona ainda uma rubrica de Pádua que não tem equivalente no livro. A rubrica seria a seguinte: "Sorri palidamente, com certo alívio como se concluísse: bem, ao menos por esse lado a coisa vai melhorar". Logo depois, ele diz para Bentinho que ambos estão crescidos, sobretudo Capitu. A intenção dos autores do roteiro parece bastante clara. O termo "melhorar", usado pelo roteiro, evidencia o interesse de Pádua numa possível namoro e casamento. Já no livro, o narrador afirma que, ao surpreender Bentinho e Capitu, ele chegou 
"sem cólera, todo meigo apesar do gesto duvidoso ou menos que duvidoso em que nos apanhou" (cap. XV).

O narrador diz ainda que Pádua era "um homem baixo e grosso, pernas e braços curtos, costas abauladas, donde the veio a alcunha de Tartaruga" (cap. XV). Continua dizendo que foi José Dias que pôs o apelido, mas que ninguém o chamava assim na casa, era apenas o agregado. A descrição do personagem no livro é mais amena e simpática, e a ação que antecede a frase sobre a idade dos dois é ainda mais amena; o livro registra: "o pai, olhando para ela e para mim, diziame, cheio de ternura".

As outras mudanças são menos significativas: o roteiro batiza o pássaro de Pádua com o nome de Chico e inverte a ordem da chegada dos personagens. No livro, Bentinho é quem entra primeiro e só depois chega Pádua. Outra mudança é que os adolescentes não dão as mãos na presença de Pádua como está no roteiro, e sim soltam as mãos quando ele entra.

O capítulo 6 do roteiro trabalha de maneira bastante interessante a relação do presente, com os dois caminhando no jardim, com o passado, a infância, por meio de flashbacks e alusões a situações que o casal viveu ou poderia ter vivido. Uma cena bem interessante do roteiro é a do casal caminhando no jardim quando é surpreendido por um casal de crianças que balança numa árvore. Esse casal, que poderia muito bem ser Bentinho e Capitu novos, na realidade é composto por dois filhos de uma escrava que passa com um trouxa de roupa na cabeça, e que são observados por Bento e Capitu adultos. Pela indicação do roteiro, no corte seguinte, as crianças pulam da árvore e ao tocarem o solo, o solo é o do flashback de Bentinho e Capitu logo após a cena do 
muro. Diz o roteiro: “E um está diante do outro, exatamente como se tivessem saltado da árvore quando, na realidade, o salto foi no tempo".

A partir daí temos, em outro flashback, a toada do pregão do escravo com um tabuleiro de doces, servindo como música de fundo para Bentinho que diz a Capitu que não vai ao seminário. Capitu chama D. Glória de beata, pega uma carta de baralho, um valete, e diz para ele falar com José Dias, pois é ele quem vai convencer D. Glória a tirá-lo do seminário. O negro das cocadas vai embora, e Capitu diz que José Dias precisa ficar do lado deles.

Todos esses episódios estão no roteiro, tratados de maneira diferente do livro e com outros fins, como já foi dito. O único que não está, que é criação do roteiro, é a cena do baralho com o valete fazendo uma alusão a José Dias. É possível relacionar as cartas aos olhos de cigana oblíqua e dissimulada de Capitu, observação feita por José Dias.

Depois disso, o roteiro volta para o presente: abre-se a janela do quarto do casal. Capitu aparece e pergunta se vai chover. Bento a abraça e eles lembram do primeiro beijo que, segundo Bento, foi uma iniciativa dela. Bento passa então a descrever a cena, dizendo que Pádua avisou que Capitu estava no quarto se penteando e pediu que ele entrasse devagarinho para pregar-lhe um susto.

O capítulo 7 começa de novo com a fusão entre passado e presente. O diálogo revive a cena de Bentinho penteando Capitu, quando eram crianças, só que a imagem descrita é a mesma do capítulo 6, com ambos já adultos. Os dois continuam na janela e Bento pega uma borboleta que ali veio pousar, pelas asas. Termina então o diálogo em off do passado no exato instante em que Bento solta a borboleta. 
Lygia e Paulo Emílio descrevem assim a passagem: "Cessam as vozes no exato instante em que Bentinho abre os dedos e solta a borboleta, como se nas suas asas fugisse também o passado".

A aparição da borboleta remete imediatamente a outro livro de Machado de Assis, Memórias póstumas de Brás Cubas, e a uma outra situação. Não se sabe se é essa a intenção dos autores do roteiro, mas cabe a lembrança da relação entre Brás Cubas e Eugênia, a flor da moita, e o episódio da borboleta preta aprisionada e esmagada por Brás, metáfora da forma como o personagem via Eugênia. No roteiro de Lygia Fagundes Telles e Paulo Emílio Salles Gomes, porém, a borboleta escapa, não é esmagada, e está relacionado ao passado. Bento, diferente de Brás Cubas, não pode esmagá-la.

Livre, portanto, a borboleta/passado foge pela janela, e o roteiro indica que câmera deve voltar para o interior do quarto, num movimento bem indicativo do caminho a ser seguido pelo roteiro: a intimidade do casal. No quarto, Capitu está sentada diante do toucador desatando o penteado. O casal refaz o diálogo da infância, e num tom mais romântico e sensual Bento diz a Capitu: "olhos de cigana oblíqua e dissimulada". Ela responde que é José Dias que achava isso e pergunta qual a opinião dele. Bento responde que "são olhos de mar de ressaca... Aquele mar que vem e me arrasta e me puxa para dentro de você". Após a fala, os dois se beijam longamente e o roteiro indica que a câmera vai à janela buscar a imagem do céu: há então uma fusão e a volta para o passado.

Antes de prosseguirmos, é preciso marcar uma diferença muito importante entre livro e roteiro. No roteiro, Capitu conhece a fala de José Dias e parece não se importar com o significado dela. O que 
mostra, mais uma vez, é que todo o episódio da denúncia, do seminário e a atitude de José Dias, são eventos superados, vistos apenas como recordações da infância - do passado liberto como a borboleta. O "atar as duas pontas da vida" do livro não existe no roteiro, visto que o ponto de irradiação do foco narrativo não é o de quem faz as suas memórias. A relação que se estabelece aqui entre o presente do roteiro, o casamento e os episódios da infância, é atenuada e muito menos complexa.

Voltando ao roteiro, depois da fusão na imagem do céu, volta-se ao passado e ao episódio no qual Capitu pergunta a Bentinho com quem ele ficaria, ela ou D. Glória. A cena é rápida. Pelo roteiro, a câmera retorna para a imagem das nuvens e refaz o caminho de volta ao presente do roteiro com Capitu dizendo que precisam sair para visitar D. Glória. Bento pergunta se Capitu já se aborreceu por estar só com ele. Ela, carinhosamente, diz que não.

Essa cena fecha o sumário narrativo do cap. Cll do livro. Mas, no livro, Bento está muito mais angustiado e enciumado, pois acha que Capitu quer se exibir para os outros.

O capítulo 8 do roteiro é bem curto. Bento e Capitu caminham pela rua, e duas velhotas fazem comentário sobre o casal. Falam sobre o casamento ocorrido no mês passado, que namoraram desde crianças, que moram na Glória e que na casa deles tem até um copeiro. A cena também está no cap.o Cll do livro. A título de curiosidade, não há, no livro, o diálogo dizendo que eles têm até copeiro. Isso está no roteiro, pois a cena que inicia o capítulo 9 se dá com o copeiro acertando o relógio da casa, enquanto Capitu toca piano. O dote musical de Capitu será bastante destacado na adaptação. No livro, há duas citações breves 
a esse respeito. No cap. CV, o narrador diz que "não sabendo piano, aprendeu depois de casada, e depressa, daí a pouco tocava nas casas de amizades". Diz depois que na Glória esse costume era comum.

O fato, porém, a ser destacado neste capítulo é a presença de Escobar e Sancha na casa de Capitu e Bento. Esses encontros serão freqüentes no roteiro, por meio de uma série de episódios inventados numa ampliação de um sumário narrativo do livro, no qual o narrador afirma que, após dois anos de casados, os casais eram bem próximos. Lygia e Paulo Emílio passam então a criar cenas e diálogos visando reconstruir e esmiuçar aquilo que no livro é dado de maneira bem resumida pelo narrador.

Em outra cena deste capítulo, Sancha elogia os dotes artísticos de Capitu. Bento diz que ela pensa até em dar concertos. Escobar pega então na mão de Capitu e diz que vê uma linha com a vocação artística. Bento, por sua vez, estende a mão a Escobar e pergunta o que ele lê na sua mão, se terá dinheiro e poder? Escobar faz pose e diz que há uma linha truncada, uma vocação que foi interrompida. Bento logo percebe a brincadeira: "De padre!". Na seqüência, Capitu oferece um bombom a Escobar, que o aceita, depois este passa a analisar o piano e as jóias de Capitu, em especial um camafeu que fora presente de D. Glória. Escobar chama Bento ao escritório. Eles fumam um charuto e conversam. Bento diz que Escobar emagreceu, e ele diz que de tanto nadar.

Podemos destacar aqui a questão da leitura de mãos, uma nova menção à cultura cigana, e de forma indireta ao olhar de cigana oblíqua e dissimulada de Capitu; e a resposta de Escobar dizendo que está magro de tanto nadar, a primeira ligação de Escobar com o mar, fato que será bem explorado depois. 
No capítulo 10 do roteiro, Sancha e Capitu estão na sala e Bento e Escobar fumam charuto no escritório. Sancha observa as estatuetas de Capitu. Capitu diz que foram presentes de D. Glória. Sancha fala das jóias de Capitu. Capitu responde que desde menina já conhecia as jóias, pois D. Glória vivia mostrando as jóias a ela. Capitu lastima que não tenha engravidado ainda e diz que Bento não pensa em outra coisa. Sancha Ihe conforta. Sancha diz que cabelos e olhos de Capitu são mais bonitos que os seus. Capitu lembra que José Dias dizia que eram olhos dissimulados e de cigana oblíqua. Sancha diz que José Dias agora só faz elogios a Capitu. Sancha fala então como Capitu acertou ao tomar a iniciativa do casamento, pega outro objeto e pergunta se foi outro presente de D. Glória. Capitu diz que este quem deu foi José Dias e que no cartão veio escrito: aos "noivos queridíssimos". Sancha diz que José Dias não conseguiu estragar o plano de Capitu. Capitu, pergunta: "que plano?". Sancha insiste. Capitu diz que não houve plano, que as coisas aconteceram.

Importante destacar aqui a insistência de Sancha em afirmar que Capitu planejou o casamento, que havia uma intenção por parte dela. Algo que no livro é sugerido de maneira mais sutil pelo próprio narrador. Outro fato a ser considerado é que o roteiro repete de forma excessiva o uso de superlativos por parte de José Dias, talvez para reforçar o aspecto cômico do personagem, que tem no roteiro um papel mais acessório.

O capítulo 11 se dá no escritório, Bento e Escobar fumam charutos, o som de fundo é de Capitu que toca piano. Escobar diz que ela progrediu rapidamente. Falam sobre vocação, e a conversa migra para a vocação de Escobar para lidar com números. Escobar pede o 
valor dos aluguéis de D. Glória e os soma de cabeça, conclui então que ela tem uma situação financeira tranqüila. Escobar percebe que Bento está preocupado e quer saber o motivo. A fala serve para um flashback para os tempos do seminário e para uma situação idêntica, só que com ambos mais jovens.

No flashback, Bentinho, com a mesma expressão do escritório, diz que Escobar foi o único que entrou no coração dele no seminário. Escobar concorda e diz que a recíproca é verdadeira, pedindo a Bentinho que confie nele. Bentinho revela então que não pode ser padre. Escobar diz que também não, que a sua paixão é o comércio. Bentinho diz que o motivo dele é outro. Escobar pergunta a Bentinho se ele tem uma namorada. Bentinho diz que sim e que gosta muito dela. Escobar fala que faria qualquer coisa para ajudar.

A oração "se eu puder ajudar..." liga novamente passado e presente e Bento revela sua angústia - a angústia do presente do roteiro - por não ter filhos. Escobar diz que Deus o dará. Bento diz: "Um triste menino que fosse, não importa, mas um filho! Eu me veria nele, continuaria nele...". Voltam então para a sala, e a música tocada por Capitu desperta em Bento o desejo de ir ao lírico. O capítulo termina com Bento dizendo que gosta de uma boa ópera.

Em relação ao livro, o cálculo dos aluguéis está no capítulo XCIV e acontece no seminário e não no presente do roteiro, quando Capitu e Bento estão casados. Quanto ao flashback no seminário, essa cena acontece no cap. LXXVIII e os diálogos são praticamente idênticos. O lamento de Bento por não ter filho aparece no cap. CIV, no qual o narrador faz um sumário de alguns fatos da vida de casado e diz que Escobar tem uma filha, cita um caso extraconjugal dele e diz que um dia 
lastimou isso com ele. As falas também são praticamente as mesmas do livro. A diferença é que depois de Escobar dizer "se não der melhor, que fiquem no céu", Bento diz: "uma criança, um filho, é o complemento natural da vida". No roteiro, Bento diz: "um triste menino, que fosse, não importa, mas um filho! Eu me veria nele, continuaria nele...". Essa fala, "um triste menino que fosse", está no livro, mas em outro capítulo, o CVIII, quando o narrador anuncia que o filho do casal havia nascido. $\mathrm{O}$ roteiro une esses dois diálogos.

Outro dado importante é a fala de Escobar, "se eu puder ajudar...", colocada da forma como está no roteiro. A justaposição dessa fala nesses dois momentos de perturbação de Bento, no passado e no presente do roteiro, pode sugerir de forma sutil o adultério e também pode sugerir tanto que Escobar quer ajudar o amigo de fato, como pode sugerir que ele esteja sendo cínico com o amigo. Afinal, se num primeiro momento a idéia de Escobar de substituir Bentinho por outro no seminário, fato que livra D. Glória da promessa, dá a Bentinho a liberdade e soluciona o problema, o mesmo pode ter ocorrido com o segundo caso, visto que a gravidez só virá depois dessa conversa entre os dois amigos.

No capítulo 12 do roteiro temos um baile. Não há nenhuma menção ao tempo decorrido entre a conversa no escritório e o baile. Esse baile existe no livro. Só que no livro o narrador cita rapidamente três bailes; o roteiro os condensa em um só. No primeiro baile do livro, Dom Casmurro observa que Capitu gostava de se enfeitar. No segundo, o narrador fala que os braços nus deixam Bento "vexado e aborrecido". No terceiro, Bento não vai e na seqüência desse episódio entra um diálogo com Escobar, sem que exista uma identificação do local em que isso acontece, no qual ele reclama ao amigo dos braços nus de Capitu. 
As falas desses diálogos são reproduzidas com bastante fidelidade na cena do baile do roteiro. No roteiro, Bento diz a Capitu que todos só prestam atenção nela. Ele dança com ela, mas logo se cansa. Capitu dança então uma quadrilha. Bento e Escobar conversam perto de uma janela, mas Bentinho não tira os olhos de Capitu. Nessa conversa, Bento diz a Escobar que não aprova o fato de Capitu vir ao baile com os braços nus. Escobar diz que não permite que Sancha faça isso. Bento fica contente por Escobar concordar com ele e brinca que as duas vão acabar chamando os dois de puritanos, de seminaristas.

Mais significativo que o baile é o desenrolar dele no capítulo 13. A cena ocorre no tílburi: Bento e Capitu voltam do baile em silêncio e afastados. Logo depois, no quarto, Bento diz que ficou chateado por causa dos braços nus e que Escobar não permite que Sancha faça isso. Capitu diz que Sancha não tem braços bem feitos. Capitu pede que Bento the desabotoe o corpete. Quer saber se ele não quer desembaraçar o cabelo dela. Bento está aborrecido. Capitu percebe e diz: "Está aborrecido logo hoje...". Bento pergunta por que logo hoje, e Capitu anuncia que está grávida e que só não contou antes porque tinha medo que ele não a levasse ao baile. No livro, não temos a cena do tílburi após o baile. Os comentários a respeito dos braços nus de Capitu estão também no cap. CV do livro. Neste mesmo capítulo, Bento comenta com Capitu que Escobar não deixa Sancha sair com os braços nus e Capitu diz que Sancha tem braços feios. O pedido de Capitu para que Bento Ihe desembarace os cabelos também não existe nesse momento do livro e muito menos o anúncio da gravidez. No livro, narrador fala do filho, já nascido, no cap. CVIII. Podemos relacionar essas diferenças ao fato de, no roteiro, o presente da narração estar centrado no casamento, o que faz com que a expectativa do filho, a frustração pela demora e o anúncio da gravidez sejam vividos de 
maneira mais intensa, diferentemente do que ocorre no livro, no qual tudo isso pertence a um passado relativamente distante e está organizado a partir de uma outra lógica de narração, orientada pelo impulso do narrador casmurro de justificar os desastres do casamento com Capitu.

I mportante destacar também uma certa insistência do roteiro em mostrar Capitu se penteando ou cuidando da sua aparência, assim como a questão dos braços nus, o que nos leva a pensar na mulher fatal analisada por Gilberto Pinheiro Passos no livro Capitu e a mulher fatal, análise da presença francesa em Dom Casmurro. Voltarei a esse ponto numa etapa seguinte do trabalho.

Outro dado interessante é a já mencionada cena com o anúncio da gravidez, que inexiste no livro. Neste, o fato aparece em um sumário narrativo que registra de imediato o nascimento: "as invejas morreram, as esperanças nasceram, e não tardou que viesse ao mundo fruto delas. Não era escasso nem feio, como eu já pedia, mas um rapagão robusto e lindo". O sumário continua com o narrador falando da criança, de como se afeiçoou a ela, da alegria de ver o bebê sendo amamentado, entre outros fatos, para, no capítulo seguinte, descrevê-lo já com cinco anos. Importante citar essa diferença, porque no roteiro temos novamente como procedimento uma distensão ou ampliação do tempo e dos episódios posteriores ao casamento, dados de forma sumária no livro.

O capítulo seguinte ao anúncio da gravidez traz Bento falando a Capitu sobre a cidade do Rio de Janeiro. Capitu parece dar mais atenção ao mar, fato que deixa Bento chateado. Capitu trata Bento com carinho e alega que estava distraída porque fazia cálculos. Ela conta que converteu suas economias em ouro e queria saber se a conversão estava certa. Bento pergunta quem foi o corretor. Ela diz que foi 
Escobar. Bento não se incomoda e pergunta o que ela fará com a fortuna. Ela diz que vai gastar no enxoval. Bento a enlaça num rodopio e diz: "Compraremos um berço de ouro, rendas de ouro, chocalhos de ouro".

Esta cena está no cap. CVI do livro, denominado, "Dez libras esterlinas". A ordem dos episódios é diferente no livro. No livro, a confissão do cálculo das economias, que conta com o auxílio de Escobar, vem antes do filho e é um dos encontros de Capitu e Escobar ao qual Bento não está presente, sugerindo a possibilidade da relação íntima dos dois. No livro, nesse momento, Bento não sabe que será pai. Outra diferença importante é que no livro Bento fica meio cismado com a ajuda de Escobar. Diferente também é o diálogo sobre o destino da quantia. No livro, o narrador diz que teve vontade de gastar o dobro do ouro em algum presente comemorativo, que Capitu o deteve e o consultou sobre o que deveriam fazer com a soma. Ele disse que era dela. Ela retrucou dizendo que era deles. Bento acaba dizendo então a ela que deveria guardar o dinheiro. A fala de Bento no roteiro, "Compraremos um berço de ouro, rendas de ouro, chocalhos de ouro", mostra os dois em comunhão. No livro, o ciúme já existe, e o descontentamento com a possibilidade de Capitu ter um dinheiro que não provém dele é imediatamente revelado pelo pensamento do narrador, que diz ter tido vontade de gastar o dobro do ouro em algum presente comemorativo. A alteração é importante, pois o episódio que no livro está relacionado ao cálculo de Capitu e Escobar, cálculo que pode e se refere também ao possível adultério, no roteiro marca apenas a união do casal em torno do filho que irá nascer. A única alusão ao ciúme é o olhar de Capitu para o mar, imagem sempre associada a Escobar. 
No capítulo 15 do roteiro, Bento e Escobar passeiam no Jardim Público. Bentinho diz a Escobar que Capitu lhe contou o segredo das economias e da conversão. Escobar diz que ele mesmo ia falar e diz que Sancha não é gastadeira, mas não poupa como Capitu. Bento diz que gastarão dinheiro no enxoval do menino. Escobar questiona sobre a certeza de ser um menino. Bento diz que o nome já está decidido e será "E-ze-quiel". Escobar se emociona. Falam depois da futura profissão do menino, passa então uma bela mulher, Escobar vira cabeça duas vezes para vê-la. Essa cena, no livro, se dá no armazém e não no Jardim Público, e está no cap. CVI. Não há menção no livro ao fato de Bento dizer que vão gastar o dinheiro no enxoval do menino. A comparação entre Sancha e Capitu também se dá de outra forma. No livro, Bento diz a Escobar que Capitu é um anjo e imagina que o mesmo não tenha concordado com ele porque não poderia dizer o mesmo de Sancha. Também inexiste a cena na qual Bento diz a Escobar que o filho deles terá o seu nome. No livro, isso ocorre em outro momento, após a questão da economia, no cap. CVIII, e com outros desdobramentos: ocorre como compensação ao fato de tio Cosme ter se colocado como padrinho de Ezequiel, função que Bento queria que fosse de Escobar. Tio Cosme chega até a pedir que a cerimônia seja logo, pois a sua saúde é fraca. Bento faz justamente o contrário, adia a cerimônia para ver se tio Cosme morre logo. Como isso não ocorre, ele acaba suprindo a "falta de compadrio", expressão do próprio livro, batizando o menino com o nome de Ezequiel. É importante lembrar que tio Cosme não existe na adaptação. Quanto à cena de Escobar olhando para a mulher que passa, ela está relacionada à menção de ele ter tido um caso extraconjugal, fato presente no livro no cap. CIV, e está aqui para marcar a possibilidade do adultério. 
A cena descrita no capítulo seguinte do roteiro, o capítulo 16 , não traz nenhuma relação direta com o livro. É a cena do piquenique no parque. Estão presentes os dois casais; as duas crianças, sendo que Ezequiel é um bebê; D. Glória, que aparece pela primeira vez no roteiro; José Dias, que também aparece pela primeira vez; mais uma mucama e uma outra escrava.

Temos uma elipse temporal facilmente identificada pelo fato de Ezequiel já ter nascido e estar no colo de Capitu que o amamenta. D. Glória é toda cuidadosa com ela. Escobar inventa um passeio de barco. Falam com José Dias sobre a Europa e ele se lamenta, dizendo: "quem me dera voltar...". A cena final do bucólico piquenique destaca os sons dos animais, e o capítulo termina com Bento chamando Ezequiel, baixinho, pois o menino acabara de despertar. Lygia e Paulo Emílio fecham esse capítulo do roteiro da seguinte forma: "Bentinho olha o céu, olha a copa da árvore, buscando o pássaro e imitando-lhe o som melodioso do canto: Ezequiel! Distante, como um eco, o pássaro repete o chamado ainda uma vez: E-ze-quieeel!...".

Como já foi dito, não existe esta cena no livro. O único fato comum é o da amamentação. No capítulo CVIII, o narrador diz que "as horas de maior encanto e mistério eram as da amamentação". Nada mais existe no livro que remeta a essa cena do roteiro.

Um ponto que deve ser citado é o episódio do pássaro imitando o nome de Ezequiel. O roteiro explora até mais que o livro essa situação. Outro dado que depois será mais analisado é a presença no roteiro, mais do que no livro também, pelo menos de forma explícita, da paisagem carioca. 
O capítulo 17, após o piqueninque, se dá na casa da Glória, e a primeira imagem descrita é justamente a de Capitu olhando para o mar. Bento se incomoda. Ela se espanta e diz: "não venha me dizer que agora está com ciúme do mar". Ele diz que sim, que tem ciúme do mar e de tudo que está dentro da cabeça dela. Na seqüência, Bento pega um lampião e brinca, dizendo que aquela é sua bola de cristal. Capitu pergunta se ele vê nela o futuro. Ele diz que só vê o passado e se lembra do "pelintra" que passava todas as a tardes a cavalo. Diz ainda que esse foi o primeiro dente de ciúme que o mordeu. Capitu quer saber qual foi o segundo. Ele diz que foi quando José Dias disse a ele no seminário que Capitu logo se casaria com qualquer peralta da vizinhança.

Deve-se destacar também, nessa primeira seqüência do capítulo 17, a relação de Capitu com o exterior, com aquilo que ela observa da janela, janela que faz divisa entre dois mundos. O ciúme de Bento está sempre relacionado com esse olhar de Capitu para fora do ambiente doméstico: o mar agora, e a rua onde o pelintra passeava a cavalo antes. Gilberto Pinheiro Passos diz que:

O espaço da janela é aquele em que podem surgir os ciúmes, exatamente porque nele há contaminação entre a atmosfera "sacrossanta" da felicidade, as exigências da lei patriarcal e a possibilidade da traição: o público espreita o privado, do mesmo modo que a figura feminina, ao olhar a rua e ser olhada pelos que nela estão, instaura o reino da ambigüidade, pois apresenta a possibilidade de se oferecer na condição de promessa (PASSOS, 2003:48).

O olhar o mar é, portanto, estar ausente em outro lugar, que não em casa; é habitar o lugar de um outro, espaço que supostamente pode ser o de Escobar. O roteiro usa de forma inteligente e sagaz esse olhar para fora como caminho para trabalhar o ciúme de Bento: tanto o do 
passado, como o do presente. E a fala de Bento no roteiro - que tem ciúme do mar e de tudo que está dentro da cabeça dela - cimenta perfeitamente esse trajeto. Deve-se destacar que no roteiro há uma inversão em relação aos episódios que motivaram o ciúme de Bentinho no passado. No livro, o primeiro dente de ciúme que morde Bentinho ocorre ainda no seminário, após uma fala de José Dias no cap. LXII, intitulado "Uma ponta de Iago". Já o segundo dente, no livro, aparece no cap. LXXIII, quando Bentinho vê Capitu na janela retribuindo o olhar para um dândi que passava na rua. Fora isso, existe a menção à bola de cristal, outro elemento da cultura cigana.

Voltando ao roteiro, a questão do ciúme explicitada agora pela fala de Bento é suspensa com a entrada em cena de Ezequiel, desta vez, já andando, com cinco ou seis anos, o que configura uma outra elipse temporal. Bento pede que Capitu toque para o menino o pregão do preto das cocadas. Capitu pergunta que pregão é esse. Bento acha estranha a pergunta dela e, sobretudo, o fato dela ter se esquecido de algo que foi tão importante na infância deles. O esquecimento é outro fato que representaria o alheamento dela, o fato de ela não habitar, mesmo que em memórias, um lugar que para Bento deveria ser do casal.

Ainda nesse capítulo do roteiro, Ezequiel pergunta para o pai sobre os soldadinhos de chumbo pintados. Bento fala depois que pretende procurar um professor de música para o menino e lembra que se mudou para perto um professor vienense que inventou um método moderno de aprendizagem de música. Fala a Capitu que Ezequiel é tão curioso quanto ela e conta a Capitu que um dia eles estavam no porão de Escobar quando viram um gato com um rato na boca. Bento não agüentou a cena, mas Ezequiel fez questão de ver o gato comendo o 
rato. Fechando o capítulo, Bento diz a Capitu que só vê um defeito no menino: o fato de ele imitar os outros. Diz também que já achou no menino um jeito dos pés de Escobar e o mesmo olhar.

Com relação ao livro, a cena de Ezequiel com o tambor existe, mas modificada. No livro, cap. CX, ele toca corneta. A história do pregão das cocadas e do soldadinho de chumbo pintado também está no livro, assim como todo o episódio do rato. O músico vienense só existe no roteiro. Já o desconforto com a mania de imitar de Ezequiel está no cap. CXII do livro. Os diálogos são bem parecidos. Só que, no livro, Bento cita que ele imita a prima Justina. No roteiro, a personagem não existe.

No capítulo 18 do roteiro, Bento sobe a escada da casa da Glória e pergunta a Capitu se ela esqueceu que hoje irão ao teatro. Ela diz que não passa bem. Capitu diz que estava lendo A Viuvinha, de José de Alencar, e que escolheu o livro pela capa. Bento conta depois que deu sua bengala a um cego e que pode usar isso no seu julgamento para não ser mandado ao inferno. Capitu diz que não existe céu, só inferno. Bento se arruma e vai para o teatro.

Não existe em Dom Casmurro menção ao livro que Capitu lê e muito menos à questão da escolha deste livro pela capa. Imagino, no entanto, que quando a história do roteiro se passa, 1865, as capas dos livros não fossem tão chamativas ou diferenciadas uma das outras, o que sugere um certo anacronismo do roteiro. Outro ponto a ser comentado é a escolha do autor e do livro. José de Alencar era um autor admirado por Machado de Assis. Em Dom Casmurro, Machado até cita Alencar num comentário do narrador, cap. LXXII, quando este fala sobre o pelintra que passou a cavalo em frente à janela de Capitu. O narrador cita a frase de uma peça de Alencar de 1858 na qual o escritor diz: 
"porque um estudante não pode estar sem estas duas cousas, um cavalo e uma namorada". Quanto ao livro citado, A Viuvinha, ele foi publicado em 1857, é um romance urbano de Alencar com trama e desenlace notadamente românticos no qual o casamento deixa de ocorrer porque o protagonista simula um suicídio, pois estava falido e queria se reerguer socialmente para reconstruir seu nome e o nome da família, voltando depois para, digamos, atar as duas pontas da vida. Existem possíveis e inúmeras ligações deste romance com a história de Capitu. A principal delas é a relação do casamento com a posição social dos noivos e o quanto o dinheiro afeta o casamento. O romance de Alencar, porém, retrata essa questão por um outro viés, romântico por excelência.

Voltando à comparação do roteiro com Dom Casmurro, também não há menção ao fato de Bento ter dado sua bengala e nem o diálogo sobre a existência do céu e inferno no contexto dado pelo roteiro. Na verdade, no livro, essa cena, na qual Bento quer ir ao teatro e Capitu não, acontece no cap. CXIII, narrada por Dom Casmurro, e ocupa pouquíssimas linhas.

Ao teatro íamos juntos; só me lembra que fosse duas vezes sem ela, um benefício de ator, e uma estréia de ópera, a que ela não foi por ter adoecido, mas quis por força que eu fosse. Era tarde para mandar o camarote a Escobar; saí, mas voltei no fim do primeiro ato. Encontrei Escobar à porta do corredor.

Como se pode perceber, o sumário narrativo do livro sintetiza em duas ou três linhas todo esse episódio, bem como a ida de Bento ao teatro, para se ocupar com mais vagar do evento que terá importância fundamental na trama: a presença de Escobar na porta da casa de Bento e Capitu. 
O roteiro por sua vez usará um capítulo inteiro para criar a cena do teatro. Nesse capítulo, o de número 19, Bento aparece primeiro no tílburi e depois já no camarote do teatro. No teatro, é entoada a modinha de Carlos Gomes: "Tão longe, de mim distante..., onde irá, onde irá teu pensamento?... Quisera, saber agora, se esqueceste, se esqueceste o juramento!...". Bento, incomodado com a música, abandona o teatro. A música o persegue no caminho, e o trecho "se esqueceste, se esqueceste o juramento!" não lhe sai da cabeça. Chegando em casa, encontra Escobar na calçada. Escobar diz que veio procurá-lo para tratar de um processo. Eles entram e conversam.

A grande preocupação de Lygia Fagundes Telles e Paulo Emílio ao colocar a modinha de Carlos Gomes no roteiro era saber se a mesma era contemporânea à ação de Dom Casmurro. No livro, no entanto, não há nenhuma menção ao que Bentinho viu no teatro. Já o diálogo do encontro com Escobar ocorre no cap. CXIII, e o seu teor é bem parecido com o do livro.

O capítulo 20 começa com Capitu abrindo a porta para Bento e Escobar. Os três conversam, Bento oferece uma xícara de chá a Escobar, mas este vai embora sem tomá-la. Bento acha que ele foi embora aborrecido. Capitu mais uma vez arruma os cabelos e depois nota Bento apreensivo. Ele diz que achou estranha a atitude de Escobar e que está achando também D. Glória estranha. Diz que ela parece constrangida e fria com o neto. A frase dele no roteiro é bastante significativa. Diz ele: "Hoje estou com tantas dúvidas, elas chegam feito ondas, me livro de uma e logo já vem outra...". Capitu acaricia Bento e diz que D. Glória pode estar doente. Ele, por sua vez, diz que precisa visitar a mãe. 
Essa frase, que relaciona as dúvidas com as ondas, só existe no roteiro; no livro, o narrador fala que Bento era um poço delas. Outra diferença é que no livro Bento visita a mãe, no mesmo capítulo. No roteiro, ele não visita a mãe.

No capítulo seguinte do roteiro, José Dias visita Bento e este pergunta se o agregado não tem notado que D. Glória está estranha. José Dias diz que não notou nada de diferente e no meio da conversa entram Ezequiel e Capitu. Ezequiel começa a imitar José Dias, Capitu o repreende. Depois, Bento diz a Capitu que o menino já está andando igualzinho ao Escobar. Essa cena está no cap. CXVI do livro, a diferença importante entre roteiro e livro é que no livro é José Dias quem pede para ver Ezequiel, a quem ele chama de profetazinho e também de "filho do homem", expressão que incomoda Capitu, que lhe pergunta sobre o porquê do termo. José Dias explica que o termo está na Bíblia. A expressão, aliás, nomeia o cap. CXVI do livro, no qual está a cena. O roteiro não usa a expressão, mas enfatiza o fato de Ezequiel imitar os outros.

O capítulo 22 do roteiro não tem nenhum equivalente no livro. A cena se passa na Praia do Flamengo em uma noite de lua cheia. Passeiam na praia os pares: Ezequiel e Capituzinha, Capitu e Escobar, Sancha e Bento. Bento diz que é raro crianças nessa idade se entenderem e se lembra dele e de Capitu. Sancha diz que eles estão ficando até parecidos. Bento diz que, de tanto imitar Escobar, Ezequiel pegou-Ihe o jeito de andar. Sancha vê uma estrela cadente. Capitu olha para o mar e diz que vai haver ressaca. Bento diz que leu num almanaque de astrologia que a lua mostrava-se particularmente volúvel. 
O capítulo seguinte acontece na casa de Escobar. Com o barulho do mar ao fundo, os dois casais jogam cartas enquanto José Dias lê uma história de fadas para as crianças. Bento vai à janela e admira a arrebentação, chama Sancha para ver o mar, e esta coloca a mão dela sobre a dele, permanecendo com a mão ali por um tempo, fato que deixa Bento petrificado. Na seqüência, Escobar diz que o mar está desafiador. Bento pergunta se ele vai nadar na manhã seguinte e apalpa, admirado, o braço do amigo. Capitu, por sua vez, está impaciente, segundo o roteiro, não se sabe se por Escobar querer enfrentar o mar ou pelo olhar de Bento a Sancha, que ela teria interceptado. Já José Dias examina os postais de Sancha e pergunta se ela os coleciona. Capitu alerta que é preciso ir, antes que nuvem escura deixe tudo em trevas.

No livro, a cena na casa de Escobar se dá no cap. CXVIII. Não há menção ao fato de José Dias ler histórias de fadas para as crianças. No livro, prima Justina também está presente, e a ordem dos fatos é diferente. Primeiro Bento lança um olhar para Sancha e a admira; depois, conversa com Escobar sobre o mar bravio; na seqüência, apalpa-Ihe os braços, mas pensando nos de Sancha, e é, na saída, que Sancha aperta a mão de Bento, fato que o deixa transtornado. Terminando o capítulo, na rua, José Dias elogia Sancha, mas não há menção alguma a postais e nem ao alerta de Capitu quanto à escuridão.

Voltando ao roteiro, o capítulo 24 é também a ampliação de um trecho que ocupa um parágrafo no livro, parágrafo que narra o percurso dos personagens que vão da casa de Escobar até a casa de Bento. No livro, a descrição da volta é rápida, e o narrador diz que conversava mal porque estava ainda pensando em Sancha. No roteiro, o trio passa por um gato, e José Dias fala que há muitos gatos em Paris; depois o 
agregado fala de um episódio envolvendo homeopatia e é cortado por Bento, que diz que já o conhece. Na seqüência, um cachorro uiva e José Dias diz que quando um cachorro uiva, é porque vê passar um anjo da morte rondando aquelas casas. No livro, não há nenhuma menção ao uivo do cachorro e nem aos gatos no livro.

A cena do capítulo 25 do roteiro ocorre no escritório de Bento. $\mathrm{Na}$ penumbra, ele fica contemplando a mão que Sancha apertou. Capitu o chama, ele diz que não irá demorar e fica vendo retratos e outros objetos, diz depois em voz alta: "Fidelitas, Fidelidade". Volta a observar os retratos e fica pensativo diante de um adolescente que se matou, um misterioso primo suicida com seus cabelos escorridos e românticos. Capitu entra no escritório. Ouvem miados de gatos, e Capitu diz que pelo menos não é o uivo do cão agourento. Capitu ajeita o coque. Bento fala que os vidros estão sujos, que o brasão da família escureceu completamente e que a mãe dele conhece um preparado para limpá-los. Relembra então que as visitas dela estão muito espaçadas e curtas. Capitu diz que são os caprichos da idade.

No livro, essa cena também se dá no cap. CXVIII, o mesmo que narra a volta da casa de Escobar, e também não é tão desenvolvida. No livro, o narrador faz uma longa digressão sobre o que aconteceu, enfatizando as dúvidas que cercam Bento diante do ato de Sancha. O único evento coincidente é o de Bento olhando para o retrato de Escobar. No livro, Capitu não entra no escritório em momento algum e nem o chama para o quarto. A menção ao retrato do primo suicida também não existe no livro e é mais um signo romântico inserido na narrativa, assim como a caracterização de Bento no início do roteiro, o livro de Alencar, a modinha de Carlos Gomes, entre outros. 
O capítulo 26 do roteiro é curto e se dá na manhã seguinte na casa da Glória. Bento leva uma rosa vermelha para Capitu, diz que nunca poderia amar outra mulher. Capitu pergunta se essa idéia já Ihe ocorreu. Ele não responde e a abraça forte. Capitu diz que tem que ir à missa. Ele, irônico, a chama de Carola, papa-missa. Bento observa Ezequiel brincando com dois pretinhos no quintal. Capitu vai à missa.

Não há essa cena no livro e nenhuma menção aos eventos nela mencionados. A fala de Bento chamando Capitu de papa-missas faz alusão à fala dela referindo-se a D. Glória, com as mesmas palavras, no início do livro, logo após a denúncia de José Dias. A ironia tem uma relação direta com o lugar ocupado por Capitu após o casamento, em tese o mesmo espaço social de D. Glória. Outro fato que merece comentário é a citação da rosa vermelha e a fala de Bentinho, dizendo que nunca poderia amar outra mulher, novos signos românticos incorporados à trama, mas postos agora em um outro terreno, não tão sólido, se pensarmos que Bento passara a noite em claro, atormentado devido à atitude de Sancha. Da mesma forma, é significativa a alusão aos vidros embaçados e ao preparado que D. Glória conhecia para limpá-los. Tal signo reflete a confusão de Bento, que começa a embaralhar os casais e as situações, não conseguindo mais entender as pessoas que estão ao seu redor e a forma como elas agem. E diante desse quadro embaçado, sem nitidez, quem poderia restituir a ordem, tornar claro de novo o brasão da família, seria D. Glória. Corrobora para essa interpretação o fato de Bento passar a enxergar a possibilidade de traição, sobretudo quando D. Glória se afasta do casal e evita o neto. Nos dois casos, ele olha pelo olhar dela, o olhar dela é essencial para que ele mantenha o equilíbrio ou se desequilibre de vez. 
O capítulo 27 começa no escritório de Bento. Ele está trabalhando quando ouve um vozerio. Sai para ver o que ocorreu e é informado por um escravo que Escobar morreu afogado. Bento pede a outro escravo que vá à I greja avisar Capitu. O roteiro indica que existe uma comoção geral na casa e que as escravas choram. O roteiro indica então uma cena em outro espaço, na antiga I greja do bairro. Lá, Capitu é vista do alto, ela está ajoelhada e rezando quando chega o mensageiro. Após ter recebido a notícia, Capitu sacode o mensageiro, grita, agarra-se ao banco e depois corre dentro da Igreja. O roteiro a descreve com a fisionomia completamente transtornada, diz que ela tem os lábios ressequidos. Depois, ela pede ao escravo que leve Ezequiel para casa.

As cenas do capítulo 27 do roteiro estão nos caps. CXX e CXXI do livro. As cenas no livro são bem sintéticas. A cena de Capitu na Igreja não existe no livro, o narrador-personagem fala apenas que se vestiu e deixou recado a Capitu, correndo então para o Flamengo. O roteiro, diferentemente do livro, faz com que Capitu receba a mensagem na I greja. Mais que isso, o roteiro indica como ela deve ser vista: do alto, ajoelhada e rezando. A imagem, ao mesmo tempo em que mostra uma Capitu religiosa, pode apontar para a culpa de Capitu. A ambigüidade da situação é bastante explorada no roteiro, que a desenvolve em tons melodramáticos.

O próximo capítulo do roteiro amplia aquilo que no livro está citado em uma linha: o resgate do corpo de Escobar. Na cena do roteiro, capítulo 28, na praia quase deserta, com o céu baixo cheio de pesadas nuvens, estão uma velha desdentada vestida de negro, um pescador e mais adiante Capitu e Sancha, observadas por três escravos. O cadáver de Escobar é retirado da praia. Bento as observa de longe. Sancha se 
desespera e é acolhida por Capitu. Bento sai para tomar as providências do enterro.

O capítulo 29 retrata o velório na casa de Escobar. A câmera, segundo indicação do roteiro, deve focalizar os escravos que conversam. Uma mucama pergunta se pode ir agora. Um escravo diz para ela esperar as pessoas saírem. Ela diz que já está quase na hora. Ela carrega a flor preferida de Escobar, os dois ficam olhando o corpo. Sancha e Capitu estão com longos véus pretos. Entre os presentes, muitos que estavam no baile. Bento chega com um padre. O roteiro narra a dor de cada personagem. José Dias informa a Bento que $D$. Glória não veio porque não se sentia bem. Um senhor pergunta a Bento se é verdade que ele falará no cemitério. Levam o corpo. Duas mãos se agarram às bordas do caixão, como querendo impedir que o levassem. Bento olha as mãos, começa a subir pelas mangas negras do vestido e reconhece que uma das mãos é de Capitu. Bento observa Capitu e Sancha. O roteiro diz que a dor de ambas é tamanha que chegam até a ficar parecidas. Bento fica atônito, sua expressão endurece, seu alvo agora não é o morto, mas Capitu. Alheio e cismado, ele esquece até de pegar seu lugar na alça do caixão: é acordado por José Dias. A mucama joga flor no caixão.

Essa cena está no cap. CXXII do livro e a narração se faz acompanhar pelo comentário do narrador. No roteiro, como tem sido recorrente, ela é bem mais desenvolvida e descritiva. No livro, não existe o diálogo dos escravos e nem menção à flor preferida de Escobar. A principal preocupação do narrador no livro é o discurso que Bento fará no enterro. Já a cena da encomenda do corpo está no cap. CXXIII do livro e é bem curta. No livro, não existe cena das mãos de Capitu agarrando o caixão. A dor de Capitu se revela mais por intermédio dos 
comentários do narrador do que por meio de ações que ele descreve. Temos, no livro, a leitura que o narrador faz do semblante de Capitu, leitura que, como todo o livro, é bastante ambígua e aberta a interpretações. Já a distração de Bento quanto ao ataúde está no início do cap. CXXIV, que trata do discurso.

Duas coisas precisam ser ditas em relação a este trecho. A primeira é a consideração do roteiro para com os escravos, sempre presentes, e aqui mais do que nunca. No livro, os escravos sempre estão à margem, como moldura silenciosa do cenário da sociedade da época. No roteiro, eles ganham o olhar da câmera, falam e agem como personagens. O segundo ponto é que, neste episódio, o roteiro assume de fato os comentários do narrador e cria uma imagem forte para tornar real aquilo que no livro pode ser posto em dúvida, visto que quem conta a história é Dom Casmurro. Entende-se a importância da cena para manter uma certa ambigüidade no caráter de Capitu e o seu propósito parece claro: atestar que o sofrimento de Capitu, por ser igual ou maior do que o da própria viúva, não é compatível com a relação que, pelo menos aparentemente, mantinha com o morto. Porém, o roteiro ao assumir uma narração em terceira pessoa, no caso a da câmera, acaba dando a esta cena um caráter de verdade inconteste. Tal fato poderia ser evitado ou mostrado de maneira mais ambígua, se Bentinho, por exemplo, olhasse duas vezes e visse uma vez a mão de Capitu e na outra apenas a mão de Sancha. Desta forma, a câmera, ao ter um duplo registro do olhar de Bento, deixaria marcada a ambigüidade deste olhar, não dando ao espectador certeza alguma. O roteiro poderia ainda optar por uma troca de olhares, mas não foi essa a opção de Lygia e Paulo Emílio. Neste episódio, mais do que aderir ao narrador do livro, o roteiro vai além, transformando qualquer tipo de dúvida em verdade. 
A ação do capítulo seguinte do roteiro, o de número 30 , se passa depois do enterro. No tílburi, Bento Santiago e José Dias voltam do cemitério. José Dias diz que o discurso foi belíssimo. Bentinho pede para o cocheiro parar e diz que se encontra com o agregado em casa. Na rua, Bentinho ouve uma canção napolitana tocada por uma rabeca: "Vede il maré quanto é bello...". A canção vem de uma barbearia. Mulher de dentro da barbearia chama o filho. Bento observa a cena familiar. Mulher oferece cocadas para Bento que as aceita, mas diz que as leva para comer depois, deixando-as no caminho, indignado que estava com a alegria da família e com o fundo musical que lhe lembrava a atmosfera da traição.

O elogio ao discurso está no cap. CXXIV do livro, na forma de uma menção rápida; a saída do cemitério no tílburi, no cap. CXXVI; e o episódio do barbeiro no cap. CXXVII. Não há menção a letra e nem mesmo se tocava uma canção napolitana. O narrador fala em uma peça executada com a rabeca. Também não há referência ao fato de a mãe chamar o filho e de oferecer cocadas a Bento.

Aqui, uma vez mais, o roteiro inclui uma letra de música enfatizar o tormento de Bento. Esse tormento será acentuado também pela presença da mãe e do filho, que remete aos pares D. Glória e Bentinho e Capitu e Ezequiel, e ao episódio da mãe oferecendo cocadas a Bento, que, por sua vez, remete ao pregão das cocadas, evento que ocorre no início do namoro de Bentinho e Capitu.

O capítulo 31 do roteiro concentra-se na casa da Glória e mostra Bentinho que chega da rua. Ele encontra José Dias na sala, conversam rapidamente. No quarto, Capitu faz Ezequiel dormir. Capitu desce para a sala e Bentinho a evita. Ele pergunta por que ela não ficou com Sancha, 
Capitu diz que havia muita gente com Sancha. Bentinho diz que mesmo assim ela deveria ter ficado com a viúva. José Dias diz que está cansado, despede-se e vai embora.

Esta cena está no cap. CXXVIII do livro. No romance, José Dias joga cartas com prima Justina, personagem que não existe no roteiro. Capitu está na sala e só depois sobe para ver o filho no quarto. Não há cena de Bentinho evitando Capitu e a censurando por não ter ficado com Sancha.

No capítulo 32, Bentinho está em seu escritório. Ele observa o retrato de Capitu adolescente e se indaga: Por quê? Por quê? Ouve a voz de Ezequiel e abre a cortina para vê-lo. Fisionomia se abranda, mas depois volta a se perturbar. Resolve sair. Na rua, Bentinho anda ao acaso, ouve conversas pela metade e apenas trechos de frases. Várias lembranças do passado Ihe perturbam a mente. Bentinho resolve ir ao teatro.

Esse tormento de Bentinho está registrado nos caps. CXXX, CXXXI e CXXXII do livro, mas é explicitado de outra forma, o narrador conta o que se passou naqueles dias, mas faz isso mais por meio de comentários e digressões do que por meio do relato de cenas. Outro dado importante que o roteiro omite é que Bento resolveu colocar Ezequiel num colégio interno.

Na seqüência do roteiro, temos a cena do teatro. Bentinho entra com a peça já começada. A peça é Otelo. Ao seu lado, um mulato de meia-idade, vestido com apuro e com pincenê com cordão preto solenemente equilibrado no nariz - a descrição remete obviamente a Machado de Assis. Lygia e Paulo Emílio exploram ainda o contraste da 
fisionomia de Bentinho com a de um casal apaixonado, e com a do mulato com seu sorriso de sabedoria meio irônica. Na peça, temos primeiro o diálogo entre Desdêmona e seu pai. Bentinho ouve uma voz que não é dos atores, dizendo: "Vós, maridos, coabitai com elas, tratando-as com honra, como a vasos mais fracos, e herdeiras convosco da graça da vida". A frase remete aos versículos da primeira epístola de S. Pedro que aparece logo no início do roteiro. Ao ouvir isso, Bentinho transita por vários estados de alma. No palco, o diálogo agora é entre Otelo e Iago. No fim do diálogo que encerra o ato, Bentinho aplaude calorosamente. O mulato diz: "Ora veja só... As grandes raivas de Otelo! Por causa de um lenço, de um simples lenço...". Começa outro ato, Bentinho acredita ter ouvido Desdêmona chamar o seu nome e não o de Otelo. Bentinho entra em transe, mistura Desdêmona e Capitu, e os diálogos de Otelo com os da sua vida. Não suportando mais, deixa a peça, totalmente transtornado.

A ida ao teatro está no cap. CXXXV. Não há menção, no livro, ao fato de Bentinho ter entrado com a peça já iniciada e nem há comentários sobre outros espectadores, como o casal e o mulato. Não há também menção de nenhum diálogo da peça, apenas um comentário do narrador sobre a questão do lenço. No livro, inexiste também o desespero de Bentinho, a confusão dos nomes dele e de Otelo e de Desdêmona e Capitu. No livro, ele vê a peça até o final, faz o narrador uma longa digressão sobre o lenço e seu papel na história e lembra que ao final da peça ele deduziu que Capitu é que tinha que morrer e não ele. Vale lembrar que no livro, a essa altura, o narrador já havia citado a intenção de Bentinho de matar-se. Fato que vai acontecer no roteiro só no capítulo seguinte ao teatro. 
No capítulo 34, Bentinho sai do teatro, entra numa farmácia e pede um veneno. $O$ farmacêutico o alerta que o tal veneno é muito perigoso. Bentinho pega o líquido e depois vai a um restaurante. No restaurante, senta e pede um vinho tinto. Toma um gole do vinho e abre o frasco. Hesita e volta a colocar o frasco no bolso. Um homem de meia-idade e cabeleira grisalha se aproxima, é Marcolino, um cantor de ópera, um cliente de Bentinho. Ele diz a Bentinho que a vida é uma grande ópera. Deus é o poeta e quem fez música foi Satanás. Diz ainda que Deus entrou com a parte pura e o "tentação" com a parte da mentira; diz que este plantou na mulher a semente da sedução e no homem, a semente do desejo. Bentinho resolve ir embora. Marcolino pega-o pelo braço e diz: "é preciso não deixar o demônio da esperança pousar de novo no coração".

Existem muitas diferenças entre este capítulo do roteiro em relação ao livro. Os episódios aqui narrados são comentados pelo narrador nos caps. CXXXIII e CXXXIV do livro. Mas a ida à farmácia não é tão detalhada e ocorre antes da peça. Já a cena do restaurante acontece depois da peça e é citada em duas linhas. O encontro com Marcolino, por sua vez, é citado no início do livro, no cap. IX, e não é informado quando Bentinho o conheceu e muito menos se é um cliente dele. No livro, o narrador diz apenas: "Dizia-me um velho italiano que aqui viveu e morreu...". O diálogo do roteiro é mais longo e traz elementos novos em relação ao narrado no livro. No livro, não se fala em sedução, tentação e nem em traição ou esperança. A frase "é preciso não deixar o demônio da esperança pousar de novo no coração" também não existe no livro. Outra mudança é que no livro ele é chamado de Marcolini e não Marcolino. 
O deslocamento dos episódios, tanto o da ida à farmácia quanto o do encontro com o tenor Marcolino são novos indícios da tentativa do roteiro de tornar mais dramático o desfecho da história de Bento. No roteiro, o personagem envenenado pelo ciúme vai à farmácia. Já no livro, a ordem é outra porque a peça serve mais como elemento para a digressão do narrador do que para a construção de uma lógica encadeada pela noção de causa e conseqüência que justifique os atos do narrador-personagem. A narração do livro é mais fria, dispersa e não busca o clímax. No roteiro, a busca desse clímax é uma opção até justificada se pensarmos que ele irá dar suporte à produção de um filme. Por outro lado, esta opção mais dramatizada está relacionada à própria construção do personagem e ao foco irradiador do ponto de vista narrativo. No livro, ele já viveu esses episódios, e os relata, podendo até mascará-los e embaralhá-los; no roteiro, não é ele quem narra, e os fatos estão acontecendo, pois este é o presente da narrativa. A forma de (re) vivenciar os episódios, portanto, é outra, como veremos na parte final deste trabalho.

Retornando a comparação, o penúltimo capítulo do roteiro, o 35, traz Bentinho no escritório. Amanhece e ele passou a noite escrevendo cartas. Num dos envelopes está o nome de José Dias; noutro, o do Senhor Intendente de Polícia. A câmera, segundo indicação do roteiro, o focaliza escrevendo uma carta para Capitu. Bentinho lê um trecho: "... que a minha primeira amiga e o meu maior amigo, tão extremosos ambos e tão queridos, quis o destino que acabassem juntando-se e enganando-me". Ele amassa o papel e escreve outra carta: "não tenho mais vontade de viver. Escobar meu amigo e...". Pára de escrever e procura uma palavra no dicionário, câmera segundo Lygia e Paulo Emílio deve mostrar então a página do dicionário onde está a palavra "comborço". Segundo roteiro, definição deve aparecer na tela. Bentinho 
termina o bilhete e escreve no envelope, D. Capitolina. Junta os envelopes ao lado do tinteiro e da figura da justiça, queima os rascunhos, tira do bolso o frasco de veneno e chama o escravo Domingos, pedindo a este uma xícara de café. Repete a palavra comborço, olhando para o retrato de Escobar. Despeja depois o veneno no café, quando é surpreendido por Ezequiel, que entra no escritório com uma casinha de pombo que ele mesmo tinha feito. Bentinho evita olhar o menino, mas depois olha para ele. Lança então um olhar agudo para o retrato de Escobar. O roteiro diz que Bentinho o vislumbra vivo dentro do porta-retrato.

Em relação ao livro, a cena de Bentinho escrevendo cartas para Capitu está no cap. CXXXV e tem um parágrafo apenas. O narrador diz que escreveu ainda uma carta, a última, para Capitu, para que essa ficasse com remorso. Diz também que escreveu dois textos, mas que queimou o primeiro por ser longo e difuso e que escreveu um segundo, bem mais conciso. O segundo falava apenas de Escobar e da necessidade de morrer. As outras cartas que são mencionadas no roteiro estão no livro no cap. CXXXIV, ou seja, o capítulo anterior àquele em que se dá a cena do teatro e no qual Bentinho compra o veneno. Só que o narrador não explicita o teor e o destinatário dessas outras cartas. Já a palavra comborço é usada pelo narrador no livro e não na carta, e não tem o destaque que ganha no roteiro. $O$ evento da xícara que ganhará destaque no último capítulo do roteiro está no cap. CXXXVI do livro, e não há menção a nenhuma casa de pombo e nem aos olhares de Bentinho para o menino e para o porta-retrato. No livro, o narrador diz apenas que se não tivesse olhado o menino é provável que não estivesse ali, escrevendo o livro. Tal comentário abre o cap. CXXXVII de Dom Casmurro. 
O último capítulo do roteiro é uma continuação da cena anterior passada no escritório. Bentinho pergunta a Ezequiel se ele já tomou café, aproxima a xícara do menino, mas desiste. Abraça e beija Ezequiel que, assustado, o chama de "papai". Bentinho diz ao menino que não é o seu pai. Nesse momento, entra Capitu. Ela pergunta a Bentinho o que está acontecendo e pede para Ezequiel sair. Bentinho repete o que disse. Capitu pergunta se ele enlouqueceu. Bentinho torna a repetir que Ezequiel não é seu filho. Capitu tremendo, diz que a única explicação que ela encontra para ele ofendê-la assim é que... Não completa a frase e pede a Bentinho que conte tudo a ela. Pergunta de onde surgiu tal idéia. Bentinho diz que há coisas que não se dizem. Capitu diz que tem o direito de se defender. Fios de cabelo se soltam do coque dela. Capitu arruma o coque nervosamente e pede para ele contar tudo ou terão que se separar. Bentinho concorda com a idéia e diz que dirá apenas um nome: Escobar. Ela, estarrecida, ri e diz: "Nem os mortos escapam do seu ciúme". Bentinho diz que Escobar está vivo. Capitu pergunta se é por causa da semelhança e diz que a vontade de Deus explica tudo. Diz que isso não a espanta e que ela acredita em Deus; e que Bentinho, apesar do seminário, não. Bentinho vacila, a chama de volta, mas no exato momento em que faz isso, entra Ezequiel, chamando a mãe para a missa. Os dois olham para o garoto. O garoto não entende o que está acontecendo. Capitu e Bentinho olham agora para o retrato de Escobar. Capitu tira Ezequiel do escritório e fala a Bentinho para ele resolver como quiser, se quer se separar, ou se quer que ela e o menino façam uma viagem. Bentinho concorda com a viagem e sugere que os dois partam para a Europa. Capitu diz que se for, não voltará mais, que morrerá longe, mas concorda e sai. Bentinho despeja o veneno na xícara e joga todo líquido pela janela. Rasga depois as cartas e pede ao escravo que the prepare um banho bem quente. Bentinho olha para o retrato de Capitu e o coloca em meio aos outros, ao acaso. Bentinho 
tem agora a expressão mais relaxada, cerra os olhos e fica ouvindo o canto de um passarinho lá fora.

Em relação ao capítulo final do roteiro, é preciso dizer que a entrada do menino que impede Bentinho de tomar o veneno está no Cap. CXXXVI do livro, e a entrada de Capitu no escritório no cap. CXXXVII. Os diálogos são bem parecidos, mas a cena do livro termina logo depois que Capitu diz que nem os mortos escapam ao ciúme de Bentinho, que tudo se deu por causa da semelhança e que ele não acredita em Deus.

Quanto à hesitação de Bentinho, no livro, ela aparece no seguinte comentário do narrador: "palavra que estive a pique de crer que era vítima de uma grande ilusão, uma fantasmagoria de alucinado; mas a entrada repentina de Ezequiel...". Já no roteiro, Bentinho com a face agoniada chega a dizer: "Ouça, Capitu...". Essa frase não existe no livro.

Já o diálogo final do roteiro, no qual decidem pela viagem de Capitu e Ezequiel, se dá de forma bem diferente no livro. Na realidade, o diálogo não existe, é uma invenção de Lygia e Paulo Emílio. No livro, após os dois olharem para a fotografia, o que para o narrador era uma confissão de Capitu, Capitu sai e vai com Ezequiel para a missa. Quando ela volta, ambos conversam, ela diz que confiou a Deus todas as suas amarguras, que a separação era indispensável e que ela estava às ordens. A viagem à Europa só vai aparecer depois como idéia de Bentinho, revelada pelo narrador no capítulo seguinte. Outra mudança menor é que no roteiro há uma cena em que Bentinho despeja o café pela janela; no livro, Bentinho diz que perdeu o gosto pela morte. A fala de Capitu dizendo que morrerá na Europa também não existe. Isso 
ocorre de fato, mas é citado pelo narrador do romance num dos capítulos finais do livro, o CXLV, no qual conta o que aconteceu com os personagens.

A adaptação termina, portanto, com o anúncio da separação, com a última fala de Capitu dizendo que viajará para a Europa e que morrerá lá, e com a cena de Bentinho sentado, relaxado na poltrona, ouvindo os pássaros. Ficamos sem saber então o que aconteceu com D. Glória, José Dias, Ezequiel, Capitu e com o próprio Bento Santiago.

\section{$\mathbf{X X X}$}

Feita a descrição do roteiro e a comparação dos episódios que compõem a adaptação de Lygia Fagundes Telles e Paulo Emílio com os episódios que compõem o livro de Machado de Assis, o próximo passo é buscar um sentido, interpretar o conjunto de diferenças verificadas na passagem do livro ao roteiro para depois tentar entender a que tipo de leitura do romance de Machado de Assis as grandes e pequenas modificações servem. 


\section{4 - As principais diferenças}

\subsection{1 - O narrador e o ponto de irradiação do foco narrativo}

A principal diferença entre o roteiro de Lygia Fagundes Telles e Paulo Emílio Salles Gomes e o livro de Machado de Assis é a opção dos autores do roteiro por um outro narrador e por um outro ponto de irradiação do foco narrativo. O narrador deixa de ser Dom Casmurro, que no livro irá atar as duas pontas de sua vida, e restaurar na velhice a infância e a adolescência, e passa a ser a câmera que, numa postura mais neutra, como um narrador em terceira pessoa, irá passear pela intimidade do casal e mostrar os episódios que ocorrem no entorno deles.

Outra mudança relacionada a esta é no ponto de irradiação do foco narrativo. No roteiro, o foco deixa de partir do passado, da velhice, para estar no casamento de Bento e Capitu e nos episódios que acontecerem a partir dali. No livro, a narrativa parte de Dom Casmurro, Bento velho, que no Engenho Novo reproduziu a velha casa de Matacavalos e passou a escrever num longo flashback a sua vida. Primeiro, explicando o título e o porquê do livro, para depois então regressar a 1857 e contar o episódio da denuncia feita por José Dias à D. Glória, na qual o agregado alertava para o namoro de Bentinho e Capitu, e, aí sim, seguir de maneira mais linear a rememoração da história de Bento e Capitu. Já no roteiro, o ponto central é o casamento, e é dele, presente da adaptação, que parte todo o ponto de vista narrativo. 
Lygia Fagundes Telles e Paulo Emílio Salles Gomes tinham uma noção clara dessa opção. A escritora, no texto que serve de introdução ao roteiro, usa as expressões "recriar literariamente" e fala em "metamorfosear um quase monólogo meditativo em imagem". O subtítulo do roteiro, "adaptação livre para um roteiro baseado no romance Dom Casmurro de Machado de Assis", também registra essa recriação por meio da expressão "adaptação livre".

A opção por um outro ponto de vista narrativo que não "monólogo meditativo", no entanto, altera significativamente a leitura do romance, pois aquilo que era central no livro deixa de existir. Desaparece com a mudança do narrador e com a mudança do ponto de irradiação do foco narrativo o discurso do narrador proprietário que faz valer a sua verdade, valendo-se da sua posição privilegiada, o que revela a estrutura social da época. Aspectos observados tanto por Helen Caldwell como por Roberto Schwarz. Deixa de existir aquilo que John Gledson chamou de narrador privilegiado, convincente e simpático, narrador que funciona como um estratagema intencionalmente concebido por Machado "para agradar o leitor, aliciá-lo no sentido de aceitar o ponto de vista do narrador" (2005:8).

Essa questão colocada por Gledson e Schwarz e detectada primeiramente por Caldwell é, sem dúvida, mais importante do que a suposta "traição ou não de Capitu". O roteiro, no entanto, ao mudar o narrador e o ponto de vista narrativo, deixa de trabalhar essa questão e coloca o casamento e a traição no centro da trama, sendo que Machado de Assis, arquitetou toda trama em torno da suposta traição para trabalhar e mascarar essa questão do discurso, da verdade que emana inconteste daqueles que detêm o poder. Como lembra Silviano Santiago em "Retórica da Verossimilhança" em Dom Casmurro há apenas uma 
única verdade: a verdade de Dom Casmurro. A verdade do proprietário de terras e escravos, ex-seminarista - ou seja, quase padre -, filho devotado à mãe e homem ligado às leis; um bacharel. Homem, como diria Roberto Schwarz, que era um dos tipos da elite mais queridos da ideologia brasileira da época.

Pois bem, essas questões todas estão anuladas no roteiro porque inexiste a figura do narrador que velho quer atar as duas pontas da vida. E sem o personagem Dom Casmurro, aquilo que é principal no livro Dom Casmurro deixa de existir, e o que temos é, de fato, uma recriação da história, ou seja, Dom Casmurro sem Dom Casmurro.

\subsection{2 - A reorganização dos episódios e suas implicações}

A opção por um outro narrador e por um outro ponto de irradiação do foco narrativo implica numa reorganização dos episódios do livro, o que por sua vez implicara numa alteração da construção dos personagens, numa alteração da relação desses personagens com esses episódios e numa alteração do processo de leitura, se tivermos em mente o processo de leitura do livro.

Esse deslocamento, processo de mudança da ordem cronológica ou espacial de elementos do livro, para usar termo de Brito e Vannoye (BRITO, 2006:11/20), é marcado pela opção dos autores do roteiro em estabelecer o casamento como ponto central da narrativa. A adaptação começa com os noivos em casa, após o casamento, e salvo alguns flashbacks, seguirá de forma linear do casamento até a separação do 
casal. Ao contrário do livro, que, como já foi dito, tem como presente da narrativa o personagem Dom Casmurro, ou seja, Bento Santiago velho.

Comecemos pela reorganização dos episódios e a implicação dessa reestruturação na construção dos personagens.

\subsubsection{1 - José Dias e os outros agregados}

O exemplo mais claro é o relacionado a José Dias. No livro, ele é uma figura central e está relacionado a um episódio igualmente central: a denúncia do namoro entre Bentinho e Capitu. O episódio da denúncia é central porque é em virtude dele que será lembrada a promessa de D. Glória de mandar Bentinho para o seminário, afastando assim o garoto de Capitu, o que dificultaria o casamento. O episódio da denúncia abre as memórias de Dom Casmurro, e seus desdobramentos irão ocupar praticamente dois terços da narrativa. Sendo José Dias o personagem principal desse episódio, nada mais natural que ele ganhe logo no início do romance uma grande importância. Mais que isso, Machado retrata por meio da figura do agregado um modelo das relações sociais vigentes na época, baseado no favor. José Dias precisava adular e mostrar-se subserviente aos interesses dos seus senhores, D. Glória e depois Bento, para poder continuar recebendo as benesses que a posição the conferia. Assim como J osé Dias, prima Justina e tio Cosme são exemplos típicos de agregados que viviam do favor.

No roteiro, o episódio da denúncia tem importância extremamente menor e é citado em flashbacks. Ele já não é mais um nó 
ou um conflito da narrativa; é, sim, um dado do passado, um evento superado visto que Bento e Capitu já estão casados. José Dias, provocador desse episódio, também deixa de ter grande importância e passa a ser um personagem menor, quase caricato na sua mania por superlativos. Superlativos que no livro também tinham uma função e se relacionavam à necessidade do agregado de ser fazer querido e, assim, obter favores.

Se o personagem de José Dias tem um papel significativamente menor, os outros personagens que também podem ser caracterizados como agregados de D. Glória e Bentinho quase não aparecem, caso de Pádua, ou não existem na adaptação, caso de prima Justina e tio Cosme.

\subsubsection{2 - Bento Santiago}

A mudança mais radical, no entanto, ocorre com o próprio Bento. Em função das mudanças já descritas, ele precisa ser construído sob uma outra ótica; ele deixa de ser o personagem-narrador para ser personagem e deixa de ser (re)construído por si próprio velho, para ser construído por um outro, no caso um narrador em terceira pessoa e teoricamente neutro. É uma criação ficcional, só que agora não de si mesmo, no caso Dom Casmurro, mas de Lygia Fagundes Telles e Paulo Emílio Salles Gomes.

Desta forma, não temos, como ocorre no livro, a visão dele sobre os episódios, mas os episódios. Porém, é impossível separá-lo desses episódios porque foi ele, na velhice, quem os construiu. Ou seja, mesmo eliminando o personagem-narrador, o roteiro vai assumir os episódios criados por ele e aceitá-los em tese como verdadeiros. A narração 
desses episódios está, numa medida ou outra, "contaminada" por esse narrador e pela opinião que ele carrega deles.

Poderíamos dizer que o processo de adaptação descola o dono do discurso, Dom Casmurro, do discurso, atar as duas pontas da vida, - o que implica em não trabalhar uma questão central do romance como já foi apontado -, mas assume os episódios que o personagem-narrador recria inserindo então o personagem nesses episódios, porém, num outro tempo e numa outra percepção desse tempo.

No livro, ao contar seu passado, o narrador o faz sob o peso dos anos e tendo refletido sobre o que ocorreu, para, serenamente, atar as duas pontas da vida. Poderíamos dizer que ao narrar sua história no livro, Dom Casmurro revive esses episódios no mínimo uma terceira vez: a primeira, quando de fato eles ocorreram; a segunda, quando os rememora e a terceira, quando os re-elabora, escrevendo-os e os fixando no papel. No roteiro, o personagem está vivendo aquilo pela primeira vez. Por isso, os roteiristas precisam virar o livro do avesso na busca de uma estrutura que reorganize os episódios dentro de uma outra lógica de percepção desses acontecimentos.

Assim, o Bento Santiago do roteiro é muito mais emotivo, romântico e perturbado que o do livro, pois passa pelos episódios no momento em que estes de fato ocorrem, sem o filtro do tempo e sem saber os desdobramentos desses episódios e o desenrolar de sua história. Por outro lado, a inserção do personagem no presente dos acontecimentos, vivendo as cenas e não as relembrando por meio de sumários narrativos, como é mais comum no livro, acaba gerando uma outra lógica de encadeamento das ações. 
Quando rememoradas, caso do livro, temos uma narrativa lacunar e fragmentada, à mercê dos caprichos de Dom Casmurro, que elege um episódio ou outro e o comenta da forma que mais lhe convém. No roteiro, a opção dos autores foi por uma estrutura narrativa na qual um episódio está relacionado ao outro, numa lógica de causa e conseqüência que chegará ao ápice, por exemplo, após a cena do velório, passando pela cena do teatro e atingirá o clímax na cena final, ambientada no escritório de Bento. O roteiro, ao dispor esses episódios posteriores ao casamento em linha reta, procura dar aos mesmos um encadeamento lógico que a narrativa memorialística do livro embaralha e envenena. Por outro lado, confere à trama uma outra emoção, resvalando no melodrama, que modificará, sobretudo, o caráter de Bento, agora não mais senhor das suas ações, mas vivendo à revelia delas.

O Bento Santiago do roteiro, ao viver esses episódios no presente, muito diferente do casmurro que virá a ser, torna-se um personagem com traços românticos num mundo ainda cheio de signos do romantismo. A lembrança, no momento em que pensava em se matar, de um primo distante que se matara por amor ilustra essa questão. Da mesma forma, a citação de A Viuvinha de José de Alencar, livro que Capitu lê, ainda que não seja ele o leitor do livro ajuda na contextualização do período.

A grande dificuldade dos autores do roteiro deve ter sido, sem dúvida, dar corpo a esse personagem que no livro é uma extensão falseada do próprio narrador que se reconstrói sem se apequenar. Dar uma dimensão humana a esse personagem que não existe não é tarefa das mais fáceis. Nesse sentido, o roteiro constrói Bento Santiago de 
forma interessante e sempre a partir do outro. Contrapondo-o a Escobar, seu amigo, mas que pode ser também aquele que ocupa o seu lugar no casamento. Fazendo com que o seu olhar precise passar pelo olhar de D. Glória; afinal, ela ao evitar o neto, torna a semelhança de Ezequiel e Escobar insuportável para Bento e é ela quem tem o preparado que, segundo Bento, pode limpar o brasão da família que está escurecido, ou seja, é ela quem pode fazer com que as coisas se reorganizem. Por outro lado, também não parece despropositado arriscar que o arranjo final, a separação, e os termos sugeridos por Capitu para pôr fim ao conflito servem para contrapor a personalidade dela, mais realista, à de Bento, ainda contaminada por laivos românticos.

Já que estamos tratando de Capitu, vejamos como o roteiro a reconstrói a partir da reorganização dos episódios do livro.

\subsubsection{3 - Capitu na janela}

No roteiro, independentemente da situação ou do episódio, um traço de Capitu é bastante marcante e recorrente: ela está sempre se penteando ou arrumando o coque. Essa mulher vaidosa e preocupada com a aparência, no roteiro até mais que no livro, está preparada o tempo todo para ser vista pelo outro ou pelos outros, o que endossa a visão que, no romance, o narrador tem da mulher, que queria voltar da lua-de-mel para ser vista; não bastava ter feito o bom casamento, era preciso mostrar-se bem casada. Da mesma forma, o roteiro, ao criar novos episódios, coloca-a sempre diante da janela, lugar em que ela 
pode ser vista e pode ver o mundo externo. Esses dois elementos, o cuidado com o cabelo e o estar à janela, são fundamentais na caracterização da Capitu do roteiro a partir da reorganização dos episódios do livro e estão diretamente relacionados entre si e também com o ciúme de Bento.

Num primeiro momento, o roteiro usa a janela como elemento de ligação entre o presente e o passado. Casados, Bento e Capitu estão no jardim e depois na janela quando recordam a infância, recordação que será materializada pelos flashbacks. Esses flashbacks vão relembrar o episódio do muro, o primeiro beijo, o pregão das cocadas, entre outros episódios da infância do casal. A janela serve então como espaço de ligação entre passado e presente num momento em que os dois ainda estão em lua-de-mel na casa na Barra da Tijuca, cujo jardim é o próprio Jardim do Éden.

O momento seguinte marca a vontade de Capitu de descer para a cidade, fato que não é bem visto por Bento, que imagina que ela queira se exibir para os outros. O desdobramento desse episódio, que no livro é importante para a conformação do ciúme de Bentinho, no roteiro marca a saída do casal do paraíso, momento no qual o olhar do outro e o olhar para o outro passam a existir, visto que o casal sai do confinamento.

Gilberto Pinheiro Passos, em Capitu e a mulher fatal, análise da presença francesa em Dom Casmurro, observa que por todos, mas - sobretudo - na condição de casada, com a honra e a 
moral preservadas, alimentando-se do olhar exterior, algo não compreendido pelo esposo, que insiste em ficar no alto da Tijuca, em lua-de-mel (PASSOS, 2003:49).

Gilberto Pinheiro Passos na seqüência do seu texto diz que o olhar público que agrada a moça contamina o marido e o episódio, ao mesmo tempo em que trata da questão do decoro de Capitu, estofa o ciúme de Bento. No roteiro, no entanto, Bento ainda está apaixonado, e o ciúme ainda não é tão presente. Passará a sê-lo só depois, quando a presença do outro, Escobar, for mais presente na vida do casal.

A partir daí, a janela terá no roteiro papel determinante. Bento passará a se incomodar com o fato de ela estar à janela, vendo o mar. A janela passará a fazer as vezes do muro, no livro. Se no romance é o muro que indica a distância social entre os dois, marcando a diferença de origem, no filme, concentrado no casamento, será a janela que marca a divisão entre o ambiente doméstico, do casamento e da fidelidade, e o ambiente público, da rua, lugar da potencial ruptura da fidelidade conjugal - ou seja, da traição.

\subsubsection{4 - Os escravos}

Ainda em relação à construção dos personagens a partir da reorganização dos episódios do livro é interessante notar como no roteiro os escravos têm uma presença bem mais significativa que no livro. Fato que fica evidenciado, sobretudo, no velório de Escobar quando um casal de escravos espera o momento de colocar uma flor no túmulo e o roteiro registra o diálogo de ambos. 
Machado de Assis, que foi até mesmo acusado de absenteísmo por não falar abertamente sobre a questão do escravo em suas obras ou por não defender de forma entusiasta a abolição, sempre colocou os escravos como moldura silenciosa do quadro social da época e não há em nenhum momento dos seus romances o registro do diálogo entre escravos. A atitude marca de maneira precisa o papel do negro na sociedade da época e foi, como definiu Silviano Santiago, "de um engajamento muito mais profundo e responsável do quem se pediu arbitrariamente a ele" (Apud TRIPOLI, 2006: 140).

A opção do roteiro, no entanto, contraria essa postura de Machado, e se mais uma vez não ajuda a recompor o quadro social da época - fato que ocorreu também quando vimos a questão do narrador/proprietário e dos agregados - talvez encontre explicação no fato do roteiro servir a um filme de o Cinema Novo que tinha como uma das características colocar na tela, sem meios tons, a questão social.

\subsubsection{5 - A paisagem como elemento de destaque}

Outro elemento que ganha destaque na adaptação é a paisagem carioca. Fato que se explica pela necessidade imperiosa do roteiro de colocar os personagens num espaço real que sirva de cenário à ação.

A esse respeito, aliás, cabe a observação que Machado sempre foi criticado por não dar uma atenção maior à descrição da paisagem, fato que levou o sociólogo francês Roger Bastide a escrever aquilo que ele chamou "de páginas de protesto contra os críticos literários que não viam o Machado paisagista". Para Bastide, Machado era um dos maiores paisagistas do Brasil, e em Machado, a natureza é terrivelmente presente, fundindo-se aos personagens. 
A natureza surge neles como uma realidade afetiva que se precisa descobrir nas entrelinhas, presente sob a forma da atmosfera que banha as pessoas, aureola-lhes os gestos, transparece-lhe as palavras. Não é, com efeito, impunemente que as casas dão para os jardins, não é impunemente que há em todos os seus romances uma janela aberta de par em par para a noite e para o mar (BASTIDE in TERESA, 2006:425).

Ao contrário da literatura romântica, literatura de glorificação da natureza brasileira, como observa Bastide, em Machado o que temos, diz ele, é a natureza vista num outro contexto histórico e social, no qual a urbanização faz com que o homem de certa forma assimile a natureza. Mais do que a descrição da paisagem, diz Bastide, o importante agora para representar esse período histórico é a arte do diálogo e da análise psicológica das personagens, resultantes da importância preponderante que assumem as conversas nos salões, nos galanteios e nas conversas relacionadas ao comércio.

Além disso, Bastide vai demonstrar - e existe aqui uma clara relação com o roteiro - que a natureza, e no caso de Dom Casmurro, o mar, é presente sempre, afetando até o estilo do escritor, que Bastide chega até a denominar de "marítimo". Diz ele: "e o mar banha Dom Casmurro nas suas ondas salgadas, verdes e turvas; ondas que vêm morrer em cada linha, deixando sobre cada palavra flocos de espuma, canções noturnas" (BASTIDE in TERESA, 2006: 426).

Lygia Fagundes Telles e Paulo Emílio Salles Gomes visualizaram muito bem essa relação e a exploram o tempo todo no roteiro. 


\subsubsection{6 - A alteração no processo de leitura}

A opção pelo casamento como ponto de irradiação do foco narrativo implicou, como já vimos, na reorganização dos episódios do roteiro e alterou a construção dos personagens e a relação destes com os episódios do livro. Fora isso, esse deslocamento tem implicações também para o processo de leitura, pois aquilo que na leitura do livro é construído como um problema, ou seja, a união de Bentinho e Capitu, é dado pelo roteiro, logo no primeiro capítulo, como um fato superado. Vejamos como isso ocorre.

O leitor ao ler o livro irá seguir todo um percurso que mostra que a união de Bentinho e Capitu fere a lógica da sociedade da época ao unir pessoas que estão e deveriam continuar apartadas socialmente. O muro é a melhor metáfora dessa condição. Quando José Dias denuncia o namoro a D. Glória, ele está cumprindo o seu papel como agregado fiel aos Santiago e mais do que isso, está revelando a todos que a possibilidade existe e deve ser combatida. Para evitar o namoro, D. Glória manda Bentinho ao seminário; tornando-se padre, Bentinho não poderia se casar com Capitu. Bentinho usa de todos os estratagemas para evitar que isso ocorra e depois faz de tudo para reverter a situação. Estes fatos que ocupam cerca de dois terços do livro e têm desdobramentos inúmeros para o entendimento do ciúme de Bentinho e do insucesso do casamento.

No entanto, todos esses eventos cujas (des)amarrações são vitais para a compreensão da impossibilidade de um final feliz para o casal - e que explicam até os motivos que levam Bentinho a ter o ciúme que tem - vão assumir, na adaptação, um papel diverso: não constitutivo ou acumulativo, mas quase decorativo. 
Longe de querer estabelecer um juízo de valor, dizer que isso é certo ou errado, o que pretendo mostrar é que o caminho que o livro percorre leva o leitor a um "passar" por episódios, que acabam por sedimentar um estado de coisas e estados de espírito. O roteiro, ao fazer outro trajeto, ao partir de outro ponto de origem e por ter outro ponto de vista narrativo, recria as mesmas cenas, só que sob outros aspectos e prismas, estabelecendo outra relação temporal e outro nexo entre passado, presente e futuro. Dessa forma, os flashbacks no roteiro, ao mesmo tempo em que dão aos personagens um passado, um antes, relativizam esse antes, que no livro eram conflitos. A percepção desse tempo anterior é outra.

Não se pode esquecer que o roteiro precisa resumir fatos, pois o filme tem uma duração menor que o livro, se pensarmos no tempo gasto para ler a obra. No entanto, essa opção por um outro ponto de irradiação do foco narrativo vai acarretar numa outra experiência de leitura, na qual a duração - aqui no sentido proposto por Bergson, sentido de acumulação, de formação, de continuidade de experiência - é quebrada, fragmentada, resultando numa outra experiência, o que confere um outro sentido à obra.

Fechando este trabalho, vejamos que outro sentido essas mudanças propõem e que leitura podemos fazer da adaptação de Dom Casmurro por Lygia Fagundes Telles e Paulo Emílio Salles Gomes. 
Conclusão 
No texto intitulado "Às vezes, novembro", que serve de introdução ao roteiro, Lygia Fagundes Telles comenta que ela e Paulo Emílio usaram de toda a liberdade na recriação de Dom Casmurro, mas sem trair o original, e se pergunta: "é possível isso? A esperança da liberdade sem traição?"

A pergunta, que se relaciona ao processo de adaptação e cabe também à personagem Capitu, encaminha bem a conclusão deste trabalho, pois nos ajuda a fechar ou responder a algumas questões levantadas durante todas estas páginas.

Pensando no processo de recriação, podemos buscar uma resposta para Lygia no próprio Machado de Assis que ao comentar, em 1878, uma adaptação de O Primo Basílio de Eça de Queirós para o teatro, ressaltou que "as obras geradas originariamente sob uma forma, dificilmente toleram outra" e que "o mau êxito cênico do Primo Basílio nada prova contra o livro e o autor da trama", sendo assim, "não há motivos para tristezas nem desapontamentos; a obra original fica isenta do efeito teatral" (ASSIS, 1955: 75).

Poderíamos pensar, portanto, apesar do anacronismo, que o próprio escritor entenderia a recriação e a relação da obra original com a obra adaptada como um processo independente, no qual o efeito da adaptação isenta a obra que a gerou de qualquer outra responsabilidade, até porque elas, como ele mesmo ressalta, são geradas sob formas diversas. E se são diversas, não existe a necessidade de ser fiel, de não trair.

Podemos ainda fazer outra relação entre a citação e a adaptação quando Machado escreve em "geradas sob formas diversas". Pois, 
apesar de o roteiro ser uma peça escrita - e no caso deste até mais literário que os outros, visto que não segue algumas formatações dos roteiros para cinema com especificações mais técnicas -, ele foi feito, como todos os roteiros, como um elemento intermediário entre o texto e o seu equivalente fílmico, ou seja, existe uma preocupação em transformar as passagens do livro em cenas, uma tentativa de visualizálas como um guia para a encenação dos atores a ser registrada pelo dispositivo técnico do cinema.

Portanto, temos o livro, o texto literário em essência, e o roteiro, adaptado também de forma literária, mas com um objetivo claro de criação de uma outra forma narrativa que seria a cinematográfica Lygia e Paulo Emílio em vários momentos chegam até a indicar posições de câmera e possíveis cortes. Isso configura aquilo que Machado chamou de formas diversas e por isso cabe a afirmação do escritor que "obras geradas originariamente sob uma forma, dificilmente toleram outra", afinal a transposição gera uma outra obra, um outro sentido.

Por outro lado, e buscando aí, sim, o sentido para as diferenças entre a adaptação e o romance, quando Lygia escreve: "é possível isso? A esperança da liberdade sem traição?", há um segundo significado embutido na frase. Numa ambigüidade tipicamente machadiana, a escritora remete também a uma possível traição ou não de Capitu e, independentemente da resposta, nos revela aquela que é a preocupação central da adaptação, ou seja, a questão do ciúme, a suposta traição e a própria instituição do casamento.

Não podemos esquecer que o roteiro foi escrito no final da década de 60 , momento em que se discutiam questões relacionadas aos direitos da mulher, a revolução sexual, entre outros temas. Época turbulenta, 
como bem registra Lygia no texto introdutório ao roteiro, com Paulo Emílio correndo o risco de ser destituído do cargo de professor da Universidade de Brasília por ser considerado subversivo. Vivia-se, como escreve Lygia, a plenitude da ditadura militar. Não há como desvincular ou perder de vista esse cenário para tentar entender a adaptação. Por outro lado, o convite ao casal de intelectuais parte do cineasta Paulo Cezar Saraceni que, por sua vez, tinha também um interesse particular na obra, como podemos observar pela forma apaixonada como ele lembra da adaptação na sua autobiografia.

eu ainda ia fazer um filme baseado em Machado de Assis, o maior romancista que um país pode desejar ter, e filmar uma obra sua, um clássico, para matar esse ciúme maluco que se apoderara de mim. Os costumes estavam mudando, a revolução sexual a toda... Vou fazer esse filme para mostrar que no Brasil o escritor Machado de Assis anteviu a revolução feminista e sexual, criticando seu tempo atrasado e repressivo (SARACENI, 1993: 217).

A adaptação assinada por Lygia Fagundes Telles e Paulo Emílio Salles Gomes - não podemos dizer o filme, pois este trabalho não chegou até ele - leu mais o Dom Casmurro personagem-escritor que o próprio Machado de Assis, autor de Dom Casmurro. Ocupou-se mais da pauta do Dom Casmurro personagem-escritor que da pauta do Machado de Assis que criou o personagem que narra suas memórias e busca atar as duas pontas da vida.

Essa formulação, que, diga-se, já foi usada por Jose Carlos Avellar ${ }^{9}$ na análise das adaptações para o cinema de Memórias póstumas de Brás Cubas, serve também e em parte para esta

\footnotetext{
9 "Klotzel leu o que Brás Cubas escreveu. Bressane leu o que Machado escreveu", afirma Avellar no livro $O$ chão da palavra - cinema e literatura no Brasil, referindo-se aos cineastas André Klotzel e Júlio Bressane e às suas adaptações de Memórias póstumas de Brás Cubas para o cinema (AVELLAR, 2007: 101).
} 
adaptação de Dom Casmurro porque é esse o principal problema ao adaptar os romances de Machado de Assis ou qualquer outra obra que seja construída com um narrador em primeira pessoa. Tanto o leitor como aquele que adapta o texto corre o risco, em maior ou menor medida, de ser capturado pelo discurso do narrador, que não é necessariamente o discurso do escritor.

Essa construção engenhosa, do escritor que escreve um livro tendo um narrador que irá escrever por sua vez o seu livro, ou seja, do livro dentro do livro, semelhante em Memórias e Dom Casmurro, ao ser descontruída faz com que a narração assuma uma forma muito diversa do original. I sso acarretará várias mudanças em relação do livro base e obviamente uma outra teia de sentidos.

Então, na adaptação de Lygia e Paulo Emílio, em vez de termos Dom Casmurro como narrador, temos uma narração em terceira pessoa; em vez de um narrador comprometido em reconstruir sua infância, adolescência e mocidade, temos a história de um casal e de um casamento; em vez da narração na velhice, o atar as duas pontas da vida, temos o deslocamento do foco irradiador do ponto de vista narrativo para um presente do roteiro, que é o casamento, mas que é o passado do livro, cujo foco irradiador do ponto de vista narrativo tem esses eventos como superados. Temos, então uma adaptação de Dom Casmurro livro sem o personagem que o nomeia: Dom Casmurro sem Dom Casmurro.

Essas e outras mudanças cujas implicações já foram discutidas no trabalho apontam, portanto, para uma outra obra que se conserva relações com a obra original é, e não poderia ser de outra forma, muito diferente desta. 
Finalizando, o que se pretendeu demonstrar é que a leitura que Lygia Fagundes Telles e Paulo Emílio Salles Gomes fizeram de Dom Casmurro é uma leitura que tematiza uma questão do livro: o ciúme e o casamento, que não é a principal do romance e que serve como um estratagema para mascarar a principal, que por sua vez não está no roteiro, e que seria a reconstrução por parte do personagem narrador da sua vida, o atar a infância e adolescência à velhice. Reconstrução por meio de um discurso que revela, por meio do que diz - uma suposta verdade - e do que não diz - nas lacunas do seu discurso -, a configuração social do Brasil do Segundo Reinado, representada pelas relações sociais da família de Dom Casmurro com os agregados que moram com eles, com os agregados que moram na casa vizinha e com outros personagens que com eles acabam convivendo.

É certo que este trabalho não esgota o tema e seria descabido pensar nessa possibilidade. O que se espera é que sirva de apoio a alguém que queira trabalhar o assunto e até mesmo para quem busca respostas para as questões das quais esta pesquisa não pôde se ocupar, entre elas a relação do roteiro com o filme. I magino ainda que possa ajudar aqueles que estudam a questão da adaptação de obras literárias para outros meios e queiram relacionar a obra de Machado de Assis com o cinema. 
Referências Bibliográficas 


\section{REFERÊNCIAS BI BLIOGRÁFICAS}

\section{VROS}

ARAUJ O, Vicente de Paula. A bela época do cinema brasileiro. São Paulo: Editora Perspectiva, 1985.

ASSIS, Machado. Dom Casmurro. Rio de Janeiro: Livraria Garnier, 1992. $\overline{1} \overline{9} \overline{5} \overline{5}$ . Crônicas 4ํ Vol. (1878-1888). Rio de Janeiro: W.M. Jackson Inc Editores.

AVELLAR, José Carlos. O chão das palavras. Cinema e literatura no Brasil. Rio de J aneiro: Ed. Rocco, 2007.

BRITO, J oão Batista de. Literatura no Cinema. São Paulo: Editora Unimarco, 2006.

CALDAS, Ricardo Wahrendorff e Tânia Montoro. A evolução do cinema brasileiro no século XX. Brasília: Editora Casa das Musas, 2006.

CALDWEL, Helen. O Otelo brasileiro de Machado de Assis. Cotia: Ateliê Editorial, 2003.

CAMPOS, Fernando Coni. Cinema: sonho e lucidez. Rio de Janeiro: Azougue Editorial, 2003.

CESAR, Ana Cristina. Literatura não é documento. Rio de Janeiro: Edição Funarte, 1980.

GLEDSON, John. Machado de Assis, impostura e realismo. São Paulo: Companhia das Letras, 2005.

GOMES, Paulo Emílio Sales. Crítica de cinema no Suplemento Literário - Volume 1. Rio de Janeiro: Editora Paz e Terra / Embrafilme, 1981.

Terra, 2001.

Cinema: trajetória no subdesenvolvimento. Rio de Janeiro: Editora Paz e

GUI MARAES, Hélio de Seixas. Os leitores de Machado de Assis: o romance machadiano e o público de literatura no século XIX. São Paulo: Nankin Editorial : Edusp, 2004

MAGALHÃES J R, R. Ao redor de Machado de Assis (Pesquisas e Interpretações). Rio de Janeiro: Editora Civilização Brasileira, 1958.

MASSA, J ean Michel. A Juventude de Machado de Assis. Rio de Janeiro: Editora Civilização Brasileira, 1971.

PASSOS Gilberto Pinheiro. Capitu e a mulher fatal: análise da presença francesa em Dom Casmurro. São Paulo: Nankin Editorial, 2003. 
PELLEGRI NI Tânia et al. Literatura, Cinema e Televisão. São Paulo: Editora Senac São Paulo: Instituto I taú Cultural, 2003.

PIZA, Daniel. Machado de Assis - Um gênio brasileiro. São Paulo: Imprensa Oficial, 2005.

RAMOS, Fernão (org.). A história do cinema brasileiro. São Paulo: Art Editora, 1990.

SALLEM, Helena. Nelson Pereira dos Santos: o sonho possível do cinema brasileiro. Rio de Janeiro: Editora Record. 1996.

SARACENI, Paulo Cesar. Por dentro do cinema novo. Rio de Janeiro: Editora Nova Fronteira. 1993.

SCHWARZ, Roberto. Duas meninas. São Paulo: Cia das Letras, 1997.

SI MÕES, Inimá. Roberto Santos, a hora e a vez de um cineasta. São Paulo: Editora Estação Liberdade, 1997.

STAM, Robert. O espetáculo interrompido - literatura e cinema de desmistificação. Rio de Janeiro: Editora Paz e Terra, 1981.

TELLES, Lygia Fagundes e Paulo Emílio Salles Gomes. Capitu. São Paulo: Editora Siciliano, 1993.

TRÍ POLI, Mailde Jerônimo. Imagens, máscaras e mitos: o negro na obra de Machado de Assis. Campinas: Editora Unicamp, 2006.

\section{ARTIGOS DE REVISTAS E J ORNAL}

BASTIDE, Roger. Machado de Assis, paisagista. Revista Teresa, Revista de Literatura Brasileira. Números 6/7, 2004/2005.

RI CCI , Cláudia Thurler. O Endereço da Civilização. Revista Nossa História, Ano 2, número 17, 2005.

FRI EDMAN, Norman. O ponto de vista na ficção. Revista da USP, São Paulo, no 53, março/maio 2002.

XAVI ER, Ismail. O avesso do Brasil. Suplemento Mais, Folha de São Paulo, 19/01/1997.

\section{SI TES DA I NTERNET}

Internet Movie Data Base: http://www.imdb.com Acessado em 20 de novembro de 2007. 
Apêndice - Cotejo livro-roteiro 


\section{Cotejo livro e roteiro}

\begin{tabular}{|c|c|c|}
\hline $\begin{array}{l}\text { Capítulo do } \\
\text { livro }\end{array}$ & Resumo do capítulo & $\begin{array}{c}\text { Equivalência no } \\
\text { roteiro }\end{array}$ \\
\hline $\begin{array}{l}\text { Cap. I - } \\
\text { Do Título }\end{array}$ & $\begin{array}{l}\text { Narrador explica título do livro. } \\
\text { No trem, vizinho recita versos a } \\
\text { Bento que cochila. Vizinho se } \\
\text { zanga e passa a chamá-lo de } \\
\text { Dom Casmurro. }\end{array}$ & Não há. \\
\hline $\begin{array}{l}\text { Cap. II - } \\
\text { Do Livro }\end{array}$ & $\begin{array}{l}\text { Narrador explica porque quer } \\
\text { escrever o livro. Fala da casa que } \\
\text { mandou construir em Engenho } \\
\text { Novo igual à da infância, em } \\
\text { Matacavalos. Intenção de atar as } \\
\text { duas pontas da vida, restaurar na } \\
\text { velhice a adolescência. Fala } \\
\text { também da idéia de escrever } \\
\text { uma "História dos Subúrbios". } \\
\text { Quadros na parede incitam a } \\
\text { escrever livro sobre o seu } \\
\text { passado. }\end{array}$ & Não há. \\
\hline $\begin{array}{l}\text { Cap. III - } \\
\text { A denúncia }\end{array}$ & $\begin{array}{l}\text { Novembro de 1857, na casa de } \\
\text { Matacavalos. José Dias } \\
\text { denuncia à Dona Glória que } \\
\text { Bentinho está metido com Capitu } \\
\text { e que isso pode atrapalhar o } \\
\text { plano dela de colocá-lo no } \\
\text { seminário. Bentinho ouve tudo } \\
\text { escondido atrás da porta. Tio } \\
\text { Cosme e prima Justina também } \\
\text { estão na cena. }\end{array}$ & $\begin{array}{l}\text { Está no roteiro, no } \\
\text { capítulo 3, como um } \\
\text { flashback. Câmera } \\
\text { subjetiva assume } \\
\text { posição de Bentinho } \\
\text { criança. Na cena, estão } \\
\text { José Dias e Dona } \\
\text { Glória. Tio Cosme e } \\
\text { Prima Justina não } \\
\text { aparecem no roteiro. } \\
\text { Falas são parecidas, } \\
\text { mas não idênticas. }\end{array}$ \\
\hline
\end{tabular}




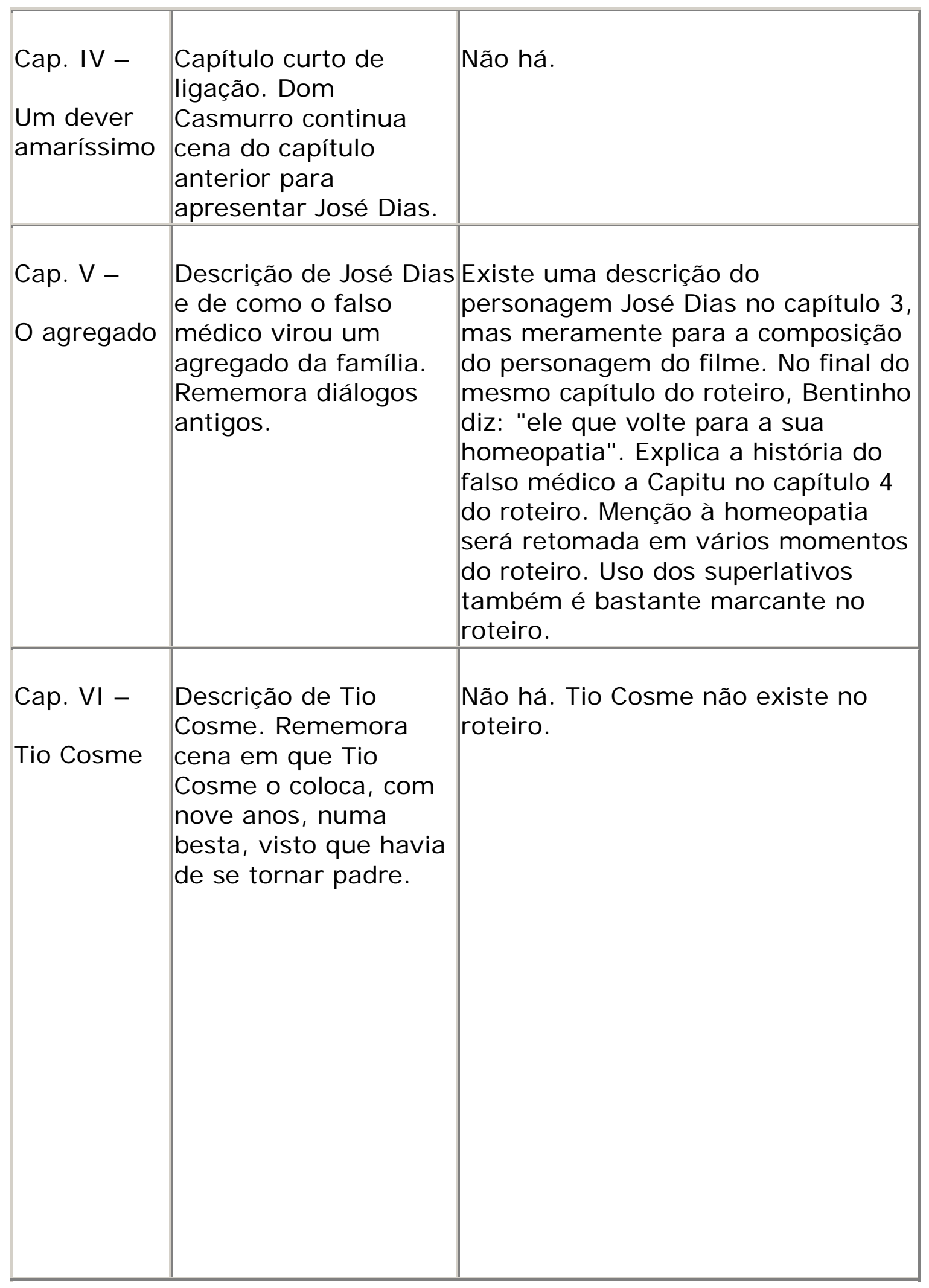




\begin{tabular}{|c|c|c|}
\hline $\begin{array}{l}\text { Cap. } \\
\text { VII - } \\
\text { Dona } \\
\text { Glória }\end{array}$ & $\begin{array}{l}\text { Descrição de Dona Glória em } \\
\text { 1846.Ano da morte do marido, } \\
\text { quando ela tinha } 31 \text { anos e } \\
\text { vendeu a fazenda e comprou } \\
\text { casas de aluguel, deixando-se } \\
\text { estar em Matacavalos. Depois } \\
\text { descrição dela em 1857: data da } \\
\text { denúncia. E por fim, descreve } \\
\text { retrato dela na parede. } \\
\text { Relaciona, numa digressão, a } \\
\text { felicidade no casamento com } \\
\text { ganhar na loteria e também com } \\
\text { mito de Pandora. }\end{array}$ & $\begin{array}{l}\text { Não há. Existe uma descrição } \\
\text { do personagem Dona Glória no } \\
\text { capítulo 3, mas meramente } \\
\text { para a composição do } \\
\text { personagem do filme. }\end{array}$ \\
\hline $\begin{array}{l}\text { Cap. } \\
\text { VIII - } \\
\text { É } \\
\text { tempo }\end{array}$ & $\begin{array}{l}\text { Capítulo curto. Dom Casmurro } \\
\text { retoma cena "daquela tarde de } \\
\text { novembro", e anuncia que cena } \\
\text { dá início à sua ópera. Cita velho } \\
\text { tenor italiano: "A vida é uma } \\
\text { ópera". }\end{array}$ & $\begin{array}{l}\text { Marcolini aparece no roteiro } \\
\text { como personagem, no capítulo } \\
34 \text { (veja abaixo). }\end{array}$ \\
\hline $\begin{array}{l}\text { Cap. } \\
\text { IX - } \\
\text { A } \\
\text { ópera }\end{array}$ & $\begin{array}{l}\text { História de Marcolini, velho } \\
\text { cantor de ópera. A vida é uma } \\
\text { ópera. Deus é o poeta, } \\
\text { compositor do libreto. Satanás é } \\
\text { o músico. }\end{array}$ & $\begin{array}{l}\text { Marcolini aparece no roteiro } \\
\text { como personagem, no capítulo } \\
\text { 34, é um cliente de Bentinho. } \\
\text { No roteiro, ele encontra } \\
\text { Bentinho por acaso, logo depois } \\
\text { que este sai do teatro, onde viu } \\
\text { Otelo. A idéia básica do capítulo } \\
\text { está no roteiro, mas outras } \\
\text { falas são adicionadas, } \\
\text { relacionando a esta idéia, da } \\
\text { autoria da composição e da } \\
\text { música do libreto, idéias } \\
\text { relacionadas à sedução e ao } \\
\text { desejo. }\end{array}$ \\
\hline
\end{tabular}




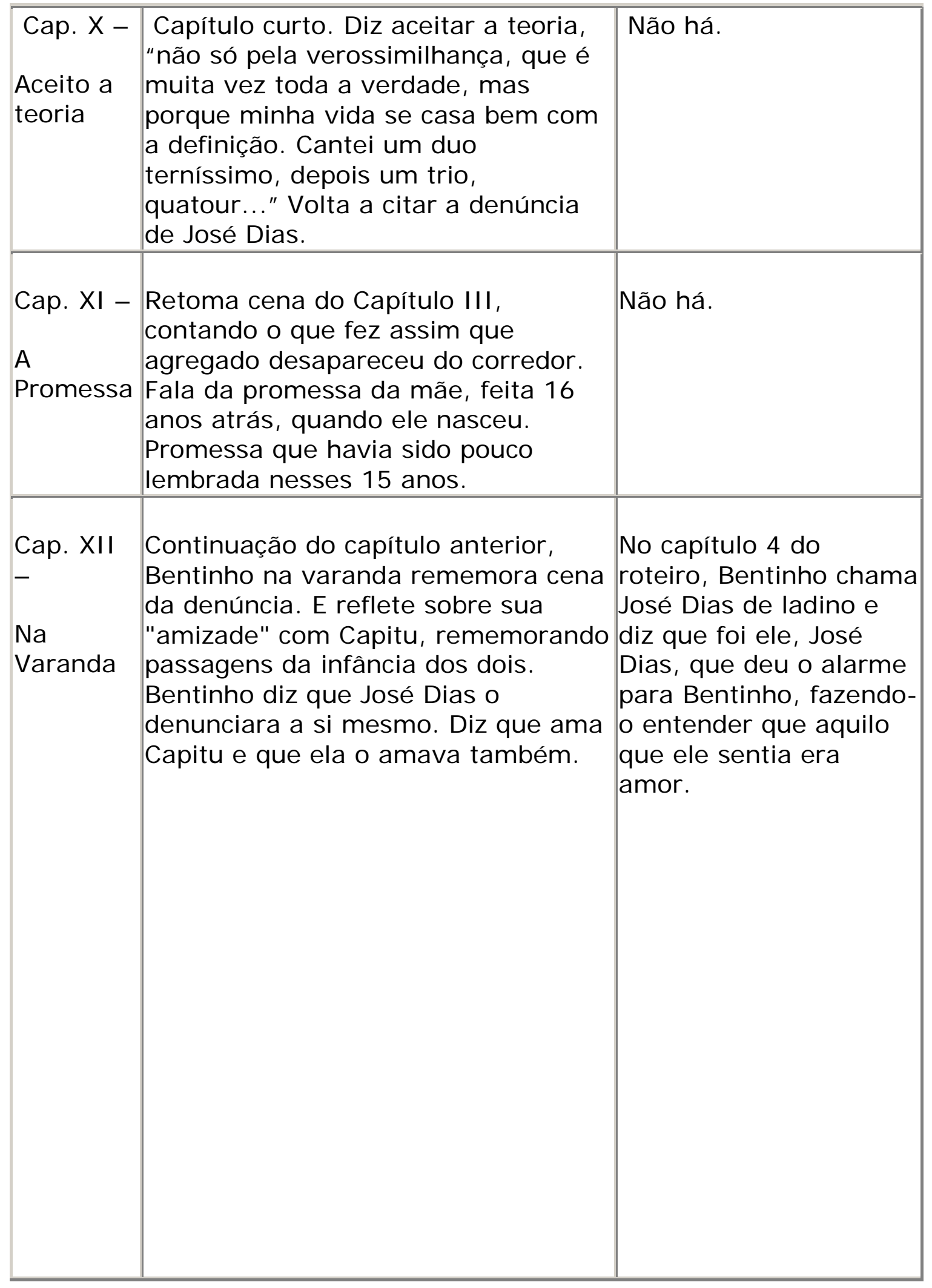




\begin{tabular}{|l|l|l|}
\hline Cap. XIII & $\begin{array}{l}\text { Continuação da cena, Bentinho } \\
\text { ouve Capitu conversando com } \\
\text { a mãe dela, Dona Fortunata. } \\
\text { Vai até o muro, na passagem } \\
\text { que separa as casas. Capitu } \\
\text { estava riscando o muro. } \\
\text { Bentinho hesita em dar a } \\
\text { notícia do seminário. Capitu } \\
\text { tenta apagar o escrito. }\end{array}$ & $\begin{array}{l}\text { No livro com o roteiro, a cena } \\
\text { aparece no capítulo 5. Não há } \\
\text { menção à mãe de Capitu no } \\
\text { roteiro. }\end{array}$ \\
\hline Cap. XIV & $\begin{array}{l}\text { Bentinho consegue ler a } \\
\text { inscrição: Bento e Capitolina. } \\
\text { "Não falamos nada, o muro } \\
\text { falou por nós". Bentinho e } \\
\text { Inscrição }\end{array}$ & $\begin{array}{l}\text { No roteiro, a cena aparece no } \\
\text { capítulo 5, como um } \\
\text { flashback. Pádua entra } \\
\text { primeiro e depois Bentinho. } \\
\text { Capitu e Bentinho dão as } \\
\text { mãos na presença de Pádua, } \\
\text { que não percebe o gesto. Não } \\
\text { se sabe ao certo se ele leu a } \\
\text { inscrição. }\end{array}$ \\
\hline Cap. XV - & $\begin{array}{l}\text { Pádua, pai de Capitu aparece. } \\
\text { Bentinho o descreve } \\
\text { fisicamente. Eles soltam as } \\
\text { mãos e Capitu vai apagar a } \\
\text { inscrição no muro. }\end{array}$ & $\begin{array}{l}\text { No livro com o roteiro, a cena } \\
\text { aparece no capítulo 5, } \\
\text { Bentinho e Pádua chegam } \\
\text { praticamente juntos, e não } \\
\text { Bentinho primeiro. Pádua } \\
\text { reclama do reboco e conversa } \\
\text { com Bentinho. }\end{array}$ \\
\hline repentinatina \\
\hline
\end{tabular}




\begin{tabular}{|c|c|c|}
\hline $\begin{array}{l}\text { Cap. XVI - O } \\
\text { administrador } \\
\text { interino }\end{array}$ & $\begin{array}{l}\text { Descreve Pádua: seu } \\
\text { padrão de vida, sua casa, a } \\
\text { relação dele e da mulher } \\
\text { com Dona Glória, a sua } \\
\text { breve ascensão social com } \\
\text { a substituição do chefe, e o } \\
\text { desespero, quando o chefe } \\
\text { voltou. Nessa ocasião, o } \\
\text { pai de Capitu confessou à } \\
\text { Dona Glória a intenção de } \\
\text { matar-se, prometendo } \\
\text { depois a ela que não se } \\
\text { mataria e que voltaria à } \\
\text { vida normal. }\end{array}$ & $\begin{array}{l}\text { Existe uma breve descrição } \\
\text { física de Pádua no capítulo } \\
5 \text { do roteiro para a } \\
\text { composição do } \\
\text { personagem. Aspectos } \\
\text { enfatizados: pobremente } \\
\text { vestido, andar vacilante, } \\
\text { apóia-se em grossa } \\
\text { bengala, um pé calçado e o } \\
\text { outro no chinelo de lã. } \\
\text { Reclama da gota e da } \\
\text { artrite. Essa descrição é } \\
\text { diferente da que Bentinho } \\
\text { faz no capítulo XV do livro. }\end{array}$ \\
\hline $\begin{array}{l}\text { Cap. XVII - } \\
\text { Os vermes }\end{array}$ & $\begin{array}{l}\text { Capítulo curto. Digressão } \\
\text { sobre a lança de Aquiles } \\
\text { que também curou uma } \\
\text { ferida que fez. }\end{array}$ & Não há. \\
\hline
\end{tabular}




\begin{tabular}{|c|c|c|}
\hline $\begin{array}{l}\text { Cap. } \\
\text { XVIII - } \\
\text { Um } \\
\text { plano }\end{array}$ & $\begin{array}{l}\text { Capitu quer saber qual notícia } \\
\text { afligia Bentinho. Ele diz que não } \\
\text { quer ser padre e revela a intenção } \\
\text { da mãe e de José Dias. Capitu } \\
\text { chama Dona Glória de beata, } \\
\text { carola e papa-missas. Bentinho se } \\
\text { desconcerta com palavras de } \\
\text { Capitu. Capitu quer saber qual } \\
\text { interesse de J osé Dias e diz a } \\
\text { Bentinho que talvez não fosse por } \\
\text { mal que Dona Glória o queria } \\
\text { Padre, mas, sim, para honrar } \\
\text { promessa. Bentinho fica mais } \\
\text { aliviado. Aparece à janela um } \\
\text { preto vendendo cocada. Capitu } \\
\text { disse que se tivesse dinheiro, } \\
\text { fugiria com Bentinho para a } \\
\text { Europa. Bentinho faz digressão } \\
\text { sobre idéias "atrevidas" de Capitu. } \\
\text { Capitu diz para Bentinho conversar } \\
\text { com José Dias e com Padre Cabral. } \\
\text { Fala a Bentinho o que ele deve } \\
\text { dizer. }\end{array}$ & $\begin{array}{l}\text { Essa cena é reproduzida } \\
\text { no capítulo } 6 \text { do roteiro, } \\
\text { num flashback. O som do } \\
\text { preto vendendo cocada } \\
\text { aparece ao fundo, diálogos } \\
\text { são menores, mas } \\
\text { parecidos com os do livro. }\end{array}$ \\
\hline $\begin{array}{l}\text { Cap. XIX } \\
\text { Sem } \\
\text { falta }\end{array}$ & $\begin{array}{l}\text { Bentinho volta para casa à noite. } \\
\text { Prepara abordagem junto a José } \\
\text { Dias, seguindo instruções de } \\
\text { Capitu. }\end{array}$ & Não há. \\
\hline $\begin{array}{l}\text { Cap. XX } \\
- \\
\text { Mil } \\
\text { padre- } \\
\text { nossos e } \\
\text { mil ave- } \\
\text { marias }\end{array}$ & $\begin{array}{l}\text { Bentinho promete rezar mil padre- } \\
\text { nossos e mil ave-marias se José } \\
\text { Dias arranjar dele não ir ao } \\
\text { seminário. A soma era enorme, } \\
\text { para compensar outras promessas } \\
\text { não pagas. }\end{array}$ & Não há. \\
\hline
\end{tabular}




\begin{tabular}{|c|c|c|}
\hline $\begin{array}{l}\text { Cap. XXI - } \\
\text { Prima } \\
\text { Justina } \\
\\
\\
\end{array}$ & $\begin{array}{l}\text { Bentinho conversa com prima } \\
\text { Justina. Ela pergunta se ele } \\
\text { gostaria de ser padre. } \\
\text { Bentinho diz que gosta do que } \\
\text { a mãe quiser. Ela diz que } \\
\text { é J osé Dias quem está } \\
\text { forçando Dona Glória a honrar } \\
\text { a promessa. Bentinho pede } \\
\text { que prima interfira junto a } \\
\text { Dona Glória. Ela fala que só } \\
\text { interferirá se perguntada. }\end{array}$ & Não há. \\
\hline $\begin{array}{l}\text { Cap. XXII } \\
- \\
\text { Sensações } \\
\text { alheias }\end{array}$ & $\begin{array}{l}\text { Bentinho continua conversa } \\
\text { com prima Justina, se } \\
\text { arrepende de ter pedido que } \\
\text { intercedesse; falam sobre } \\
\text { Capitu. Bentinho teme que ela } \\
\text { suspeite de seus sentimentos } \\
\text { por Capitu. }\end{array}$ & Não há. \\
\hline $\begin{array}{l}\text { Cap. XXIII } \\
\text { Prazo dado } \\
\end{array}$ & $\begin{array}{l}\text { Bentinho diz a José Dias que } \\
\text { precisa falar com ele. Marcam } \\
\text { de conversar no dia seguinte. }\end{array}$ & Não há. \\
\hline $\begin{array}{l}\text { Cap. XXIV } \\
\text { De mãe e } \\
\text { de servo }\end{array}$ & $\begin{array}{l}\text { Capítulo curto, Bentinho fala } \\
\text { sobre como J osé Dias o } \\
\text { tratava. Diz que José Dias o } \\
\text { tratava com extremos de mãe } \\
\text { e atenções de servo, } \\
\text { elogiando-o sempre. }\end{array}$ & Não há. \\
\hline
\end{tabular}




\begin{tabular}{|c|c|c|}
\hline Cap. XXV & $\begin{array}{l}\text { Bentinho e José Dias } \\
\text { conversam no passeio público. } \\
\text { Bentinho diz que a última vez }\end{array}$ & $\begin{array}{l}\text { Não há equivalente da } \\
\text { conversa no passeio. }\end{array}$ \\
\hline $\begin{array}{l}\text { No Passeio } \\
\text { Público }\end{array}$ & $\begin{array}{l}\text { que esteve no passeio foi com } \\
\text { Pádua. José Dias recrimina } \\
\text { Bentinho por andar com } \\
\text { Pádua, pois ele pode ir } \\
\text { ganhando confiança. José Dias } \\
\text { diz que família de Capitu não é } \\
\text { de toda má, fala também que } \\
\text { Capitu tem olhos de cigana } \\
\text { oblíqua e dissimulada e que } \\
\text { Pádua riu dele. Bentinho diz } \\
\text { que Pádua o elogiou, } \\
\text { comparando-o a um deputado. } \\
\text { Bentinho toma coragem e fala } \\
\text { a José Dias que não quer ser } \\
\text { padre e que conta com o } \\
\text { agregado para livrá-lo da } \\
\text { promessa. José Dias diz que } \\
\text { não quer outra coisa a não ser } \\
\text { servi-lo. Bentinho diz que não } \\
\text { é por vadiagem e que, se } \\
\text { fosse o caso, iria a São Paulo } \\
\text { estudar Direito. }\end{array}$ & $\begin{array}{l}\text { Quanto à expressão: "tem } \\
\text { olhos de cigana oblíqua e } \\
\text { dissimulada", no roteiro, } \\
\text { Bentinho diz isso para Capitu } \\
\text { enquanto a penteia, já } \\
\text { casados, no capítulo 7. Ela } \\
\text { diz a ele que era José Dias } \\
\text { que a chamava assim. No } \\
\text { livro, ela desconhece a } \\
\text { expressão. }\end{array}$ \\
\hline $\begin{array}{l}\text { Cap. XXVI } \\
\text { - } \\
\text { As leis são } \\
\text { belas }\end{array}$ & $\begin{array}{l}\text { José Dias diz que falará com } \\
\text { Dona Glória, que há boas } \\
\text { universidades pelo mundo } \\
\text { afora, sugere que ele e } \\
\text { Bentinho viajem juntos. Fala a } \\
\text { Bentinho que este deve } \\
\text { conversar também com o seu } \\
\text { tio. }\end{array}$ & Não há. \\
\hline $\begin{array}{l}\text { Cap. XXVII } \\
\text { Ao portão }\end{array}$ & $\begin{array}{l}\text { Capítulo bem curto, no passeio } \\
\text { Bentinho dá esmola a mendigo } \\
\text { e pede a este que rogue a } \\
\text { Deus por ele. }\end{array}$ & Não há. \\
\hline
\end{tabular}




\begin{tabular}{|c|c|c|}
\hline $\begin{array}{l}\text { Cap. XXVIII } \\
- \\
\text { Na rua } \\
\end{array}$ & $\begin{array}{l}\text { Capítulo curto, Bentinho nota } \\
\text { J osé Dias mudado e passa a } \\
\text { tratá-lo de forma mais } \\
\text { carinhosa. }\end{array}$ & Não há. \\
\hline $\begin{array}{l}\text { Cap. XXIX - } \\
\text { O Imperador }\end{array}$ & $\begin{array}{l}\text { Encontram I mperador no } \\
\text { caminho. Bentinho pensa em } \\
\text { pedir a Imperador que } \\
\text { intercedesse a seu favor } \\
\text { junto à Dona Glória. I magina } \\
\text { a cena dele com o I mperador } \\
\text { e imagina o I mperador em } \\
\text { sua casa. }\end{array}$ & Não há. \\
\hline $\begin{array}{l}\text { Cap. XXX - } \\
\text { O Santíssimo }\end{array}$ & $\begin{array}{l}\text { Acompanham o santíssimo. } \\
\text { Pádua e J osé Dias disputam } \\
\text { uma das varas do pálio. } \\
\text { Pádua a cede a Bentinho. } \\
\text { Entram na casa de uma } \\
\text { enferma. Filha da enferma } \\
\text { faz Bentinho lembrar de } \\
\text { Capitu. Ele se consterna por } \\
\text { ela, e vai do choro ao riso. } \\
\text { José Dias o repreende por } \\
\text { rir. Narrador ressalta } \\
\text { humilhação de Pádua. }\end{array}$ & Não há. \\
\hline $\begin{array}{l}\text { Cap. XXXI - } \\
\text { As } \\
\text { curiosidades } \\
\text { de Capitu }\end{array}$ & $\begin{array}{l}\text { Bentinho se encontra com } \\
\text { Capitu. Ela diz que prefere } \\
\text { tudo ao seminário, inclusive } \\
\text { a idéia dele ir à Europa. } \\
\text { Bentinho fala em pedir ajuda } \\
\text { do Imperador, ela o corta e } \\
\text { pergunta quando J osé Dias } \\
\text { irá falar com Dona Glória. Ela } \\
\text { pede que Bentinho Ihe conte } \\
\text { tudo, todos os gestos. } \\
\text { Bentinho diz que ela era } \\
\text { mais mulher do que ele era } \\
\text { homem e que era muito } \\
\text { curiosa. }\end{array}$ & Não há. \\
\hline
\end{tabular}




\begin{tabular}{|c|c|c|}
\hline $\begin{array}{l}\text { Cap. XXXII - } \\
\text { Olhos de } \\
\text { Ressaca }\end{array}$ & $\begin{array}{l}\text { Alguns dias após o ajuste } \\
\text { com o agregado, Bentinho } \\
\text { vai falar com Capitu. } \\
\text { Encontra-a na sala, } \\
\text { penteando o cabelo. Capitu } \\
\text { pede para Bentinho teimar } \\
\text { com José Dias. Bentinho } \\
\text { pensa na expressão "olhos } \\
\text { de cigana oblíqua e } \\
\text { dissimulada". }\end{array}$ & $\begin{array}{l}\text { No roteiro, Bentinho, } \\
\text { casado, na janela do quarto } \\
\text { de casal, ouve esse diálogo } \\
\text { de infância. Cena está no } \\
\text { capítulo } 6 \text { e } 7 \text { do roteiro. } \\
\text { Quanto à expressão "olhos } \\
\text { de cigana oblíqua e } \\
\text { dissimulada", ele fala isso } \\
\text { para ela, e ela diz que era } \\
\text { josé Dias quem pensava } \\
\text { assim. No livro, repito, ela } \\
\text { desconhece esses termos. } \\
\text { Depois, ele diz que achava } \\
\text { que ela tinha "olhos de } \\
\text { ressaca", o que dá origem a } \\
\text { um beijo. }\end{array}$ \\
\hline $\begin{array}{l}\text { Cap. XXXIII } \\
- \\
\text { O Penteado }\end{array}$ & $\begin{array}{l}\text { Bentinho penteia Capitu. Os } \\
\text { dois se beijam. }\end{array}$ & $\begin{array}{l}\text { Cena do penteado é revivida } \\
\text { no presente do roteiro, no } \\
\text { capítulo } 7 \text {, ou seja, com os } \\
\text { dois já casados. }\end{array}$ \\
\hline $\begin{array}{l}\text { Cap. XXXIV } \\
\text { Sou homem! }\end{array}$ & $\begin{array}{l}\text { Dona Fortunata aparece para } \\
\text { chamar Bentinho. Capitu se } \\
\text { recompõe rápido, o que } \\
\text { assusta Bentinho. Em casa, } \\
\text { Bentinho se surpreende ao } \\
\text { pronunciar, sem pensar, } \\
\text { como se a boca falasse } \\
\text { sozinha, que "é homem". } \\
\text { Corre até a porta para ver se } \\
\text { alguém ouviu. Fica a pensar } \\
\text { no beijo. }\end{array}$ & $\begin{array}{l}\text { Não há. Dona Fortunata não } \\
\text { aparece no roteiro. }\end{array}$ \\
\hline
\end{tabular}




\begin{tabular}{|c|c|c|}
\hline $\begin{array}{l}\text { Cap. XXXV - } \\
\text { O Protonotário } \\
\text { apostólico }\end{array}$ & $\begin{array}{l}\text { Lição de latim com o Padre } \\
\text { Cabral, que acabara de ser } \\
\text { nomeado protonotário } \\
\text { apostólico. Bentinho é } \\
\text { dispensado da aula, mas } \\
\text { mãe diz que ele será um } \\
\text { padre lindo. Protonotário } \\
\text { Santiago, diz o padre. } \\
\text { Bentinho recua, mas tem } \\
\text { vontade de dizer um } \\
\text { desaforo. Narrador } \\
\text { descrever o padre. }\end{array}$ & Não há. \\
\hline $\begin{array}{l}\text { Cap. XXXVI - } \\
\text { Idéia sem } \\
\text { pernas e sem } \\
\text { braços }\end{array}$ & $\begin{array}{l}\text { Bentinho vai brincar, mas } \\
\text { tem vontade de ir até } \\
\text { Capitu, desfazer-lhe as } \\
\text { tranças e beijá-la. Acaba } \\
\text { indo. Ela o olha "a furto e a } \\
\text { medo". Ele pergunta se a } \\
\text { mãe dela a repreendeu. Ela } \\
\text { diz que não. Bentinho pensa } \\
\text { em beijá-la, mas ela está } \\
\text { retraída. }\end{array}$ & Não há. \\
\hline $\begin{array}{l}\text { Cap. XXXVII - } \\
\text { A alma é cheia } \\
\text { de mistérios }\end{array}$ & $\begin{array}{l}\text { Falam da aula que não } \\
\text { ocorreu e do padre. Capitu } \\
\text { pede para ir ver o padre. } \\
\text { Bentinho puxa Capitu para } \\
\text { si. Ela recua e depois cede. } \\
\text { Ouvem voz de Pádua que } \\
\text { chega. Capitu beija Bentinho } \\
\text { antes que o pai dela entre } \\
\text { pelo portão. }\end{array}$ & Não há. \\
\hline
\end{tabular}




\begin{tabular}{|c|c|c|}
\hline $\begin{array}{l}\text { Cap. XXXVIII - } \\
\text { Que susto, } \\
\text { meu Deus! }\end{array}$ & $\begin{array}{l}\text { Pádua aparece, Capitu } \\
\text { disfarça. Narrador ressalta } \\
\text { que ela se dominava tanto } \\
\text { na presença do pai quanto } \\
\text { da mãe. O coração não Ihe } \\
\text { batia nem mais, nem } \\
\text { menos, diz ele. }\end{array}$ & Não há. \\
\hline $\begin{array}{l}\text { Cap. XXXIX - } \\
\text { A vocação }\end{array}$ & $\begin{array}{l}\text { Capitu vai falar com Padre } \\
\text { Cabral. Na casa, estão J osé } \\
\text { Dias, Tio Cosme, Prima } \\
\text { Justina e Dona Glória. Falam } \\
\text { sobre vocação religiosa e } \\
\text { Padre Cabral fala que levou } \\
\text { caso de Bentinho ao reitor } \\
\text { de São J osé. Capitu está } \\
\text { cosendo as saias de Dona } \\
\text { Glória. Capitu vai embora. } \\
\text { D. Glória pede que Bentinho } \\
\text { a acompanhe. Escrava } \\
\text { flagra os dois juntos. }\end{array}$ & Não há. \\
\hline $\begin{array}{l}\text { Cap. LX - Uma } \\
\text { égua }\end{array}$ & $\begin{array}{l}\text { Capítulo digressivo. Outra } \\
\text { fantasia de Bentinho. } \\
\text { Relaciona visita imperial, } \\
\text { casa do Engenho Novo que } \\
\text { reproduz Matacavalos e } \\
\text { éguas iberas, à imaginação. } \\
\text { Fantasia seria a } \\
\text { possibilidade de confessar à } \\
\text { mãe que não tem vocação } \\
\text { religiosa e do namoro com } \\
\text { Capitu; beijo e tudo mais. }\end{array}$ & Não há. \\
\hline
\end{tabular}




\begin{tabular}{|c|c|c|}
\hline $\begin{array}{l}\text { Cap. LXI - A } \\
\text { audiência } \\
\text { secreta }\end{array}$ & $\begin{array}{l}\text { Capítulo retoma o anterior, } \\
\text { Bentinho volta à sala. Mãe } \\
\text { pergunta se ele } \\
\text { acompanhou Capitu. Ele } \\
\text { pede para falar à mãe. Ela } \\
\text { acha que ele está doente. } \\
\text { Ele pergunta do seminário, } \\
\text { quando irá. Ela diz que só } \\
\text { depois das férias. Ele } \\
\text { pergunta se vai para ficar. } \\
\text { Ela diz que ele retornará aos } \\
\text { sábados e que, sendo } \\
\text { padre, morará com ela. } \\
\text { Afagam-se, ele diz que "só } \\
\text { gosta da mamãe". Ao } \\
\text { comentar a frase, Narrador } \\
\text { diz que a mentira é, muita } \\
\text { vez, tão involuntária como a } \\
\text { transpiração. Narrador diz } \\
\text { que Bentinho volta a ser o } \\
\text { filho submisso. Bentinho } \\
\text { sugere a ela que pedisse a } \\
\text { Deus a dispensa da } \\
\text { promessa. Ela se recusa. }\end{array}$ & Não há. \\
\hline $\begin{array}{l}\text { Cap. LXII - } \\
\text { Capitu } \\
\text { refletindo }\end{array}$ & $\begin{array}{l}\text { No dia seguinte, Bentinho } \\
\text { vai à casa de Capitu. } \\
\text { Comentam as novidades do } \\
\text { dia anterior. Bentinho conta } \\
\text { que conversou com Dona } \\
\text { Glória. Capitu não passou } \\
\text { bem à noite, Bentinho fica } \\
\text { triste de vê-la naquele } \\
\text { estado, ela reflete... }\end{array}$ & Não há. \\
\hline
\end{tabular}




\begin{tabular}{|c|c|c|}
\hline $\begin{array}{l}\text { Cap. LXIII - } \\
\text { Você tem } \\
\text { medo? }\end{array}$ & $\begin{array}{l}\text { Capitu pergunta a Bentinho } \\
\text { se ele tem medo e se } \\
\text { aborrece com a hesitação } \\
\text { dele ao responder. Depois } \\
\text { se desculpa e diz que não } \\
\text { está se sentindo bem. Vão } \\
\text { até o quintal. }\end{array}$ & Não há. \\
\hline $\begin{array}{l}\text { Cap. LXIV - O } \\
\text { primeiro filho? }\end{array}$ & $\begin{array}{l}\text { Capitu pergunta a Bentinho } \\
\text { quem ele escolheria: ela ou } \\
\text { a mãe? Ele hesita, diz que a } \\
\text { mãe dele não é capaz de Ihe } \\
\text { perguntar isso. Ela refaz a } \\
\text { pergunta. Sugere a hipótese } \\
\text { dele estar no seminário e } \\
\text { ela estar morrendo de } \\
\text { saudades, querendo saber } \\
\text { se, nesse caso, mesmo se a } \\
\text { mãe Ihe impedisse de vir, se } \\
\text { ele obedeceria à mãe ou } \\
\text { não. Capitu escreve } \\
\text { mentiroso no chão. Bentinho } \\
\text { não entende o que ela } \\
\text { escreve e o que ela fala. } \\
\text { Imaginam-se separados. } \\
\text { Ele, cônego; ela, casada. } \\
\text { Bentinho pede a ela que } \\
\text { prometa que só se } \\
\text { confessará com ele, e que } \\
\text { só ele poderia casá-la. } \\
\text { Capitu refaz a segunda } \\
\text { promessa, dizendo que ele } \\
\text { batizará o primeiro filho } \\
\text { dela, visto que ele } \\
\text { demoraria a se ordenar } \\
\text { padre, o que a faria esperar } \\
\text { muito por um casamento. }\end{array}$ & $\begin{array}{l}\text { Esse diálogo aparece no } \\
\text { capítulo } 7 \text { do roteiro, logo } \\
\text { após a cena do penteado. } \\
\text { Cena é revivida no } \\
\text { presente do roteiro, ou } \\
\text { seja, com os dois já } \\
\text { casados. O diálogo deste } \\
\text { capítulo aparece num } \\
\text { flashback e tem início após } \\
\text { ambos ouvirem um } \\
\text { chamado de Dona Glória } \\
\text { por Bentinho. Capitu reage } \\
\text { assustada e faz a pergunta } \\
\text { se ele escolheria ela ou a } \\
\text { mãe? O diálogo não é } \\
\text { reproduzido de forma } \\
\text { integral no roteiro, termina } \\
\text { quando Bentinho diz para } \\
\text { ela não falar em morrer. }\end{array}$ \\
\hline
\end{tabular}




\begin{tabular}{|c|c|c|}
\hline $\begin{array}{l}\text { Cap. LXV - } \\
\text { Abane a } \\
\text { cabeça, leitor }\end{array}$ & $\begin{array}{l}\text { Dom Casmurro se dirige ao } \\
\text { leitor e comenta as palavras } \\
\text { de Capitu: "falou do } \\
\text { primeiro filho, como se } \\
\text { fosse a primeira boneca". } \\
\text { Hipótese de perder Capitu } \\
\text { para outro assusta } \\
\text { Bentinho. }\end{array}$ & Não há. \\
\hline $\begin{array}{l}\text { Cap. LXVI - As } \\
\text { pazes }\end{array}$ & $\begin{array}{l}\text { Narrador comenta sobre as } \\
\text { pazes e solta um comentário } \\
\text { interessante: "buscasse eu } \\
\text { nesse livro a minha glória, e } \\
\text { diria que as negociações } \\
\text { partiram de mim; mas não, } \\
\text { foi ela que as iniciou". } \\
\text { Abraçam-se, Dona Fortuna } \\
\text { os surpreende de novo. } \\
\text { Capitu se diz estranha, com } \\
\text { dor de cabeça, abatimento } \\
\text { do espírito, "os seus } \\
\text { calundus". }\end{array}$ & Não há. \\
\hline $\begin{array}{l}\text { Cap. LXVII - } \\
\text { "A Senhora } \\
\text { saiu." }\end{array}$ & $\begin{array}{l}\text { Bentinho quer saber porque } \\
\text { ela perguntou se ele tinha } \\
\text { medo de apanhar, se era } \\
\text { por causa do seminário. Faz } \\
\text { digressões a respeito da } \\
\text { questão. }\end{array}$ & Não há. \\
\hline
\end{tabular}




\begin{tabular}{|c|c|c|}
\hline $\begin{array}{l}\text { Cap. LXVIII - } \\
\text { Juramento do } \\
\text { poço }\end{array}$ & $\begin{array}{l}\text { Bentinho pede para Capitu } \\
\text { jurar que só há de se casar } \\
\text { se for com ele. Ela não } \\
\text { hesita e diz que mesmo que } \\
\text { ele se casasse com outra, } \\
\text { ela não se casaria nunca. } \\
\text { Bentinho também jura que } \\
\text { só se casará se for com ela. } \\
\text { Ela muda o juramento, } \\
\text { juram que hão de se casar } \\
\text { um com o outro. Passam a } \\
\text { aceitar a hipótese do } \\
\text { seminário, mas Bentinho } \\
\text { afirma que não se } \\
\text { ordenará. }\end{array}$ & Não há. \\
\hline $\begin{array}{l}\text { Cap. LXIX- } \\
\text { Uma vela aos } \\
\text { sábados }\end{array}$ & $\begin{array}{l}\text { Capítulo curto, digressão e } \\
\text { comentário sobre o episódio } \\
\text { anterior. }\end{array}$ & Não há. \\
\hline $\begin{array}{l}\text { Cap. L - Um } \\
\text { meio termo }\end{array}$ & $\begin{array}{l}\text { Bentinho diz que meses } \\
\text { depois foi ao seminário, e } \\
\text { narra momento da partida. } \\
\text { Diz que padeceu e que sua } \\
\text { mãe também. Diz que Padre } \\
\text { Cabral achara um meio- } \\
\text { termo: se no fim de dois } \\
\text { anos não fosse revelada a } \\
\text { vocação eclesiástica, } \\
\text { Bentinho seguiria outra } \\
\text { carreira. Dom Casmurro } \\
\text { narra que Capitu se tornou } \\
\text { mais íntima de Dona Glória. }\end{array}$ & Não há. \\
\hline $\begin{array}{l}\text { Cap. LI - } \\
\text { Entre luz e } \\
\text { fusco }\end{array}$ & $\begin{array}{l}\text { Narra a despedida dele e de } \\
\text { Capitu, com beijo e reforço } \\
\text { do juramento. }\end{array}$ & Não há. \\
\hline $\begin{array}{l}\text { Cap. LII - O } \\
\text { velho Pádua }\end{array}$ & $\begin{array}{l}\text { Narra a despedida dele e de } \\
\text { Pádua. }\end{array}$ & Não há. \\
\hline
\end{tabular}




\begin{tabular}{|l|l|l|}
\hline $\begin{array}{l}\text { Cap. LII - O } \\
\text { caminho }\end{array}$ & $\begin{array}{l}\text { Narra sua despedida de } \\
\text { Prima Justina, Tio Cosme e } \\
\text { José Dias. Relembra } \\
\text { hipótese da viagem à } \\
\text { Europa. }\end{array}$ & Não há. \\
\hline $\begin{array}{l}\text { Cap. LIV - } \\
\text { Panegírico de } \\
\text { Santa Mônica }\end{array}$ & $\begin{array}{l}\text { Narra os tempos no } \\
\text { seminário e sobre o } \\
\text { panegírico de Santa Mônica. }\end{array}$ & Não há. \\
\hline $\begin{array}{l}\text { Cap. LV - Um } \\
\text { soneto }\end{array}$ & $\begin{array}{l}\text { Fala a respeito de um } \\
\text { soneto feito no tempo de } \\
\text { seminário. Analisa }\end{array}$ & Não há. \\
longamente dois versos: & $\begin{array}{l}\text { "Oh, flor do céu! Oh! Flor } \\
\text { cândida e pura. Perde-se a } \\
\text { vida. Ganha-se a batalha". }\end{array}$ & \\
\hline Cap. LVI - & $\begin{array}{l}\text { Fala como conheceu } \\
\text { Escobar. Tornam-se } \\
\text { confidentes. }\end{array}$ & Não há. \\
\hline seminarista & $\begin{array}{l}\text { Capítulo curto que cria } \\
\text { curiosidade em relação ao } \\
\text { próximo, narrador se dirige } \\
\text { ao leitor. }\end{array}$ & Não há. \\
\hline Cap. LVII - \\
Da preparaçã
\end{tabular}




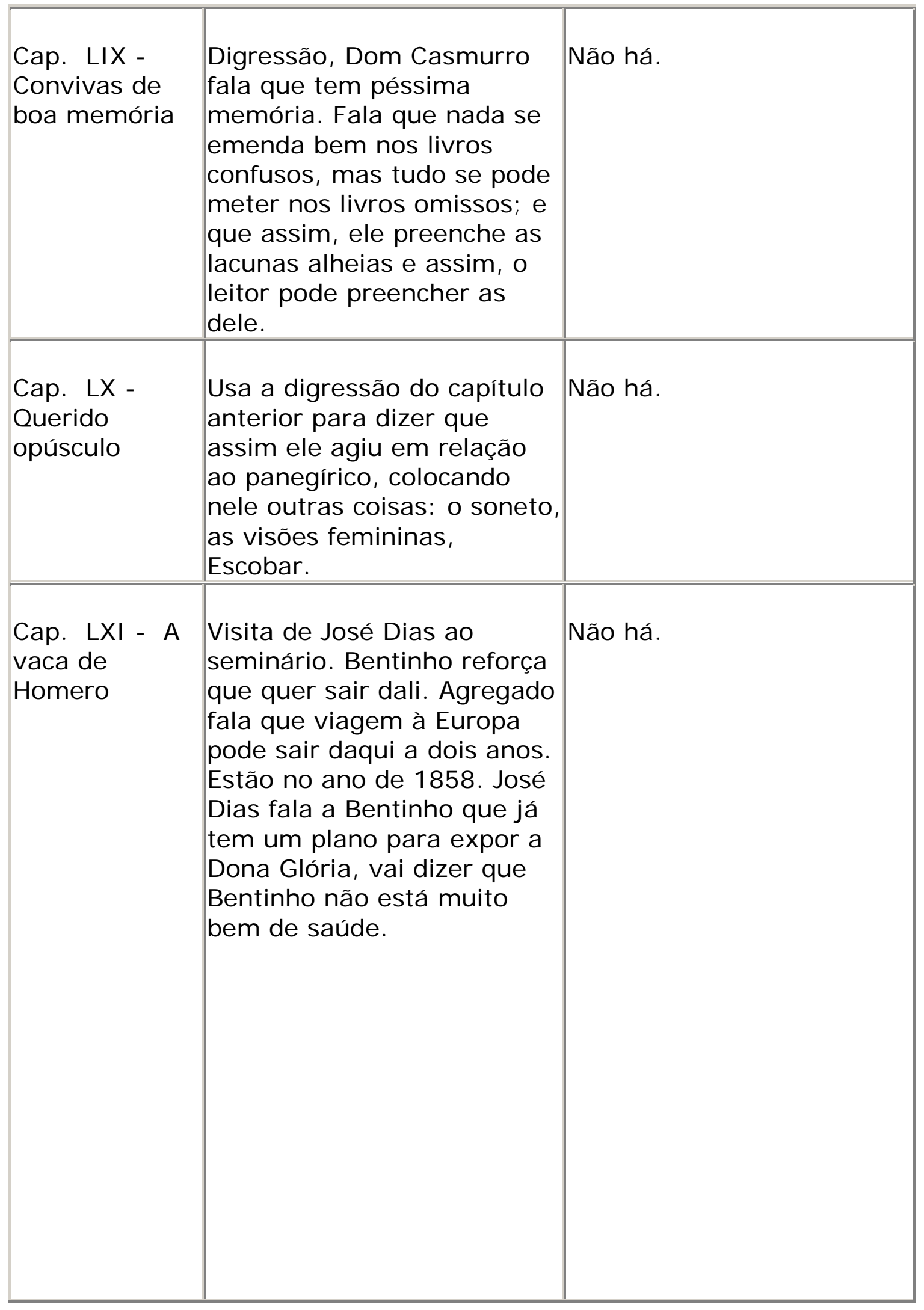




\begin{tabular}{|c|c|c|}
\hline $\begin{array}{l}\text { Cap. LXII - } \\
\text { Uma ponta de } \\
\text { Iago }\end{array}$ & $\begin{array}{l}\text { Bentinho pergunta por } \\
\text { Capitu. José Dias diz que ela } \\
\text { anda alegre como sempre: } \\
\text { "é uma tontinha. Aquilo } \\
\text { enquanto não pegar } \\
\text { nenhum peralta da } \\
\text { vizinhança, que case com } \\
\text { ela...". Bentinho empalidece } \\
\text { e nasce o ciúme, imagina } \\
\text { que ele já tenha outro } \\
\text { namorado. Bentinho quer } \\
\text { visitar família. J osé Dias diz } \\
\text { que ele poderá ir no } \\
\text { próximo sábado. }\end{array}$ & $\begin{array}{l}\text { Menção a esse fato aparece } \\
\text { no capítulo } 17 \text { do roteiro, } \\
\text { numa fala de Bentinho. } \\
\text { Bentinho diz a Capitu que } \\
\text { esse foi o segundo dente } \\
\text { de ciúme que o mordeu. O } \\
\text { primeiro seria um } \\
\text { pelintra que passava a } \\
\text { cavalo pelo bairro. Roteiro } \\
\text { inverte fatos. No livro, } \\
\text { pelintra ou dandy, aparece } \\
\text { depois. }\end{array}$ \\
\hline $\begin{array}{l}\text { Cap. LXIII - } \\
\text { Metades de } \\
\text { um sonho }\end{array}$ & $\begin{array}{l}\text { Bentinho fica ansioso pela } \\
\text { chegada do sábado. } \\
\text { Narrador relembra de um } \\
\text { sonho que teve nesse dia, } \\
\text { quando viu Capitu na janela } \\
\text { com um desses peraltas. Há } \\
\text { no sonho um bilhete de } \\
\text { loteria, } 4004 \text {. Divaga sobre } \\
\text { a estranheza da simetria do } \\
\text { número. Bentinho demora a } \\
\text { dormir. }\end{array}$ & Não há. \\
\hline $\begin{array}{l}\text { Cap. LXIV - } \\
\text { Uma idéia e } \\
\text { um escrúpulo }\end{array}$ & $\begin{array}{l}\text { Dom Casmurro fala sobre o } \\
\text { capítulo passado. Sobre a } \\
\text { reprodução da casa de } \\
\text { Matacavalos, da intenção de } \\
\text { atar as duas pontas da vida, } \\
\text { e relaciona essa idéia ao } \\
\text { sonho: "um dos ofícios do } \\
\text { homem é fechar e apertar } \\
\text { muito os olhos, a ver se } \\
\text { continua pela noite velha o } \\
\text { sonho truncado da noite } \\
\text { moça". Faz digressão sobre } \\
\text { o sonhar e cita Luciano de } \\
\text { Samosata. }\end{array}$ & Não há. \\
\hline
\end{tabular}




\begin{tabular}{|c|c|c|}
\hline $\begin{array}{l}\text { Cap. LXV - A } \\
\text { dissimulação }\end{array}$ & $\begin{array}{l}\text { Passam-se os sábados, } \\
\text { Bentinho se afeiçoa à vida } \\
\text { nova: casa-seminário, } \\
\text { seminário-casa. Bentinho } \\
\text { fica mais amigo de Escobar. } \\
\text { Chega a dizer para Capitu } \\
\text { que confidenciaria a este o } \\
\text { namoro de ambos. Capitu } \\
\text { pede que não conte. Dom } \\
\text { Casmurro rememora diálogo } \\
\text { e cena na qual Capitu, Dona } \\
\text { Glória, J osé Dias e Bentinho } \\
\text { estão na casa de Dona } \\
\text { Glória, e Capitu respondeu à } \\
\text { mãe de Bentinho que } \\
\text { achava que Bentinho daria } \\
\text { um bom padre. A convicção } \\
\text { da resposta irrita e cisma } \\
\text { Bentinho. Depois ele } \\
\text { entende a dissimulação } \\
\text { dela. }\end{array}$ & Não há. \\
\hline $\begin{array}{l}\text { Cap. LXVI - } \\
\text { Intimidade }\end{array}$ & $\begin{array}{l}\text { Dom Casmurro narra que } \\
\text { Capitu se aproximou de } \\
\text { Dona Glória. Diz que Prima } \\
\text { Justina se aborrecia com } \\
\text { essa proximidade e com } \\
\text { cuidados de Capitu para } \\
\text { com Dona Glória que } \\
\text { adoecera. }\end{array}$ & Não há. \\
\hline $\begin{array}{l}\text { Cap. LXVII - } \\
\text { Um pecado }\end{array}$ & $\begin{array}{l}\text { Dona Glória que está doente } \\
\text { manda buscar Bentinho no } \\
\text { seminário, temia morrer e } \\
\text { por isso, o queria por perto. } \\
\text { No caminho, Bentinho pensa } \\
\text { que se mãe morresse, } \\
\text { acabava o seminário. Tem } \\
\text { depois remorso pelo } \\
\text { pensamento. Chegando na } \\
\text { casa, Bentinho se ajoelha ao } \\
\text { pé da cama de Dona Glória. }\end{array}$ & Não há. \\
\hline
\end{tabular}




\begin{tabular}{|l|l|l|}
\hline $\begin{array}{l}\text { Cap. LXVIII - } \\
\text { Adiemos a } \\
\text { virtude }\end{array}$ & $\begin{array}{l}\text { Dom Casmurro usa } \\
\text { confissão para ganhar } \\
\text { confiança do leitor, dizendo } \\
\text { que para escrever a própria } \\
\text { essência é preciso contá-la } \\
\text { toda, o bem e o mal. } \\
\text { Digressão sobre a questão. }\end{array}$ & \\
\hline $\begin{array}{l}\text { Cap. LXIX - Aa há. } \\
\text { missa }\end{array}$ & $\begin{array}{l}\text { Bentinho vai à missa no } \\
\text { domingo seguinte agradecer } \\
\text { o restabelecimento da mãe } \\
\text { e pede perdão pelo pecado } \\
\text { de associar morte dela ao } \\
\text { fim da promessa. }\end{array}$ & Não há. \\
\hline Cap. LXX - & $\begin{array}{l}\text { Bentinho encontra Sancha, } \\
\text { amiga de Capitu, na saída } \\
\text { da missa. Sancha estava } \\
\text { com o seu pai. Sancha pede } \\
\text { notícias de Dona Glória. } \\
\text { Bentinho os acompanha e } \\
\text { fica um pouco na casa } \\
\text { deles. }\end{array}$ & \\
\hline Não há. \\
\hline Cap. LXXII - \\
Uma reforma \\
dramática & $\begin{array}{l}\text { Capítulo digressivo, sem } \\
\text { nenhuma relação aparente } \\
\text { Com a trama. Fala que as } \\
\text { peças deveriam começar } \\
\text { pelo fim. Cita Otelo e seu } \\
\text { desfecho. }\end{array}$ & \\
\hline Escobar & $\begin{array}{l}\text { Escobar visita Bentinho e } \\
\text { janta com a família, } \\
\text { causando-lhes boa } \\
\text { impressão. Despedem-se e } \\
\text { Capitu os espreita da janela. } \\
\text { Depois, indaga Bentinho } \\
\text { quem era o amigo a quem } \\
\text { demonstrara tanto afeto. }\end{array}$ & \\
\hline Não há. \\
\hline
\end{tabular}




\begin{tabular}{|c|c|c|}
\hline $\begin{array}{l}\text { Cap. LXXIII - } \\
\text { O contra- } \\
\text { regra }\end{array}$ & $\begin{array}{l}\text { Continua a digressão, } \\
\text { dizendo que o destino é o } \\
\text { contra-regra e o } \\
\text { dramaturgo. Relaciona essa } \\
\text { coincidência do destino com } \\
\text { a estada na janela, quando } \\
\text { passou um dandy que olhou } \\
\text { para Capitu, sendo que essa } \\
\text { retribuiu o olhar. Narrador } \\
\text { diz que foi o segundo dente } \\
\text { de ciúmes que mordeu } \\
\text { Bentinho. }\end{array}$ & $\begin{array}{l}\text { No capítulo } 17 \text { do roteiro, } \\
\text { Bentinho depois de dizer } \\
\text { que sente ciúme até do } \\
\text { mar, diz que primeiro dente } \\
\text { de ciúme que o mordeu foi } \\
\text { de um pelintra que } \\
\text { passeava pelo bairro. No } \\
\text { livro, esse é o segundo } \\
\text { dente. No roteiro, é o } \\
\text { primeiro. Há uma inversão. }\end{array}$ \\
\hline $\begin{array}{l}\text { Cap. LXXIV - } \\
\text { A presilha }\end{array}$ & \begin{tabular}{|l|} 
Tio Cosme e José Dias \\
conversam na sala. Ao ver \\
J osé Dias, Bentinho lembra \\
da fala dele e da história do \\
peralta. Bentinho relaciona \\
esse ao dandy e pensa em \\
perguntar ao agregado se a \\
afirmação era verdadeira ou \\
hipotética. José Dias \\
percebe a aflição e pergunta \\
a Bentinho se aconteceu \\
alguma coisa. Bentinho \\
responde que a presilha da \\
calça do agregado está \\
desabotoada.
\end{tabular} & Não há. \\
\hline $\begin{array}{l}\text { Cap. LXXV - } \\
\text { O desespero }\end{array}$ & $\begin{array}{l}\text { Bentinho escapa ao } \\
\text { agregado, escapa à mãe, } \\
\text { mas não a si mesmo e ao } \\
\text { ciúme. Entra em desespero } \\
\text { e imagina cravar as unhas } \\
\text { no pescoço de Capitu. }\end{array}$ & Não há. \\
\hline
\end{tabular}




\begin{tabular}{|c|c|c|}
\hline $\begin{array}{l}\text { Cap. LXXVI - } \\
\text { Explicação }\end{array}$ & $\begin{array}{l}\text { Bentinho fica mal, dorme } \\
\text { mal. Vê que ciúme tomou } \\
\text { uma proporção grande. Fala } \\
\text { a Capitu do ocorrido. Capitu } \\
\text { diz que é uma grande } \\
\text { injúria e chora. Diz que } \\
\text { nunca mais irá à janela. } \\
\text { Bentinho diz que não era } \\
\text { necessária tal promessa. } \\
\text { Capitu concorda, e diz que } \\
\text { primeira nova suspeita em } \\
\text { relação a ela, tudo estaria } \\
\text { dissolvido entre eles. } \\
\text { Narrador conta que } \\
\text { Bentinho aceitou a ameaça, } \\
\text { e jurou que era a primeira e } \\
\text { última suspeita. }\end{array}$ & Não há. \\
\hline $\begin{array}{l}\text { Cap. LXXVII - } \\
\text { Prazer das } \\
\text { dores velhas }\end{array}$ & $\begin{array}{l}\text { Capítulo bem curto, } \\
\text { narrador lembra da crise do } \\
\text { amor adolescente e fala que } \\
\text { aquelas dores chegaram a } \\
\text { se diluir no prazer. }\end{array}$ & Não há. \\
\hline $\begin{array}{l}\text { Cap. LXXVIII } \\
\text { - Segredo por } \\
\text { segredo }\end{array}$ & $\begin{array}{l}\text { Bentinhp conta seu segredo, } \\
\text { ou parte dele, a Escobar. } \\
\text { Diz que não pode ser padre. } \\
\text { Escobar diz que também } \\
\text { não, que tem vocação para } \\
\text { o comércio, e não para a } \\
\text { religião. Bentinho lhe conta } \\
\text { de Capitu e o convida para } \\
\text { jantar. Escobar elogia Dona } \\
\text { Glória. }\end{array}$ & $\begin{array}{l}\text { Esta cena no seminário é } \\
\text { um flashback no roteiro, } \\
\text { está no capítulo } 11 \text {. As } \\
\text { falas são praticamente } \\
\text { idênticas. Não há o convite } \\
\text { para o jantar e nem o } \\
\text { elogio à Dona Glória. }\end{array}$ \\
\hline $\begin{array}{l}\text { Cap. LXXIX - } \\
\text { Vamos ao } \\
\text { capítulo }\end{array}$ & $\begin{array}{l}\text { Bentinho contente por } \\
\text { Escobar ter elogiado Dona } \\
\text { Glória. Narrador pensa na } \\
\text { mãe, segundo ele, adorável. } \\
\text { Capítulo serve de prefácio } \\
\text { ao seguinte. }\end{array}$ & Não há. \\
\hline
\end{tabular}




\begin{tabular}{|c|c|c|}
\hline $\begin{array}{l}\text { Cap. LXXX - } \\
\text { Venhamos ao } \\
\text { capítulo }\end{array}$ & $\begin{array}{l}\text { Fala sobre a promessa da } \\
\text { mãe; que se pai estivesse } \\
\text { vivo, talvez a promessa } \\
\text { fosse outra e voltada à } \\
\text { política; fala da reforma da } \\
\text { promessa; da assiduidade } \\
\text { de Capitu na casa de Dona } \\
\text { Glória, depois da ida dele ao } \\
\text { seminário, e que ela se } \\
\text { tornou "a flor da casa". }\end{array}$ & Não há. \\
\hline $\begin{array}{l}\text { Cap. LXXXI - } \\
\text { Uma palavra }\end{array}$ & $\begin{array}{l}\text { Bentinho fica sabendo que } \\
\text { Capitu está na casa de } \\
\text { Sancha; prima Justina } \\
\text { insinua que podem estar lá, } \\
\text { namorando. Bentinho fica } \\
\text { com ciúmes, quer "matá- } \\
\text { la"; vai até a casa do pai de } \\
\text { Sancha que está doente, } \\
\text { onde conversa com Capitu. }\end{array}$ & Não há. \\
\hline $\begin{array}{l}\text { Cap. LXXXII - } \\
\text { O canapé }\end{array}$ & $\begin{array}{l}\text { Bentinho conversa com } \\
\text { Capitu. Diz que foi a mãe } \\
\text { quem Ihe mandou que fosse } \\
\text { até a casa do pai de } \\
\text { Sancha. Capitu diz que eles } \\
\text { serão felizes. }\end{array}$ & Não há. \\
\hline $\begin{array}{l}\text { Cap. LXXXIII } \\
\text { - O retrato }\end{array}$ & $\begin{array}{l}\text { Gurgel, o pai de Sancha, diz } \\
\text { a Capitu que Sancha a } \\
\text { chama. Capitu despede-se } \\
\text { de Bentinho que a admira. } \\
\text { Gurgel diz que ela já é uma } \\
\text { moça e que era parecida } \\
\text { com o retrato da mulher } \\
\text { dele. "Na vida há dessas } \\
\text { semelhanças assim } \\
\text { esquisitas", diz o narrador. }\end{array}$ & Não há. \\
\hline
\end{tabular}




\begin{tabular}{|c|c|c|}
\hline $\begin{array}{l}\text { Cap. LXXXIV - } \\
\text { O chamado }\end{array}$ & $\begin{array}{l}\text { Bentinho volta para casa e } \\
\text { na rua é informado que } \\
\text { Manduca morreu. Fica sem } \\
\text { saber o que fazer: não quer } \\
\text { ver um defunto, depois de } \\
\text { ter visto a namorada. }\end{array}$ & Não há. \\
\hline $\begin{array}{l}\text { Cap. LXXXV - } \\
\text { O defunto }\end{array}$ & $\begin{array}{l}\text { Bentinho vai ver o defunto. } \\
\text { Pai de Manduca pergunta se } \\
\text { ele faria o favor de ir ao } \\
\text { enterro. Bentinho diz que } \\
\text { faria o que a mãe dele } \\
\text { quisesse. }\end{array}$ & Não há. \\
\hline $\begin{array}{l}\text { Cap. LXXXIII } \\
\text { - Amai, } \\
\text { rapazes! }\end{array}$ & $\begin{array}{l}\text { Capítulo curto. Bentinho } \\
\text { volta para casa e pensa em } \\
\text { Capitu e no defunto. "Amai, } \\
\text { rapazes! E, principalmente, } \\
\text { amai moças lindas e } \\
\text { graciosas; elas dão remédio } \\
\text { ao mal, aroma ao infecto, } \\
\text { trocam a morte pela vida.." }\end{array}$ & Não há. \\
\hline $\begin{array}{l}\text { Cap. LXXXIII } \\
\text { - A sege }\end{array}$ & $\begin{array}{l}\text { Entrando em casa, resolve } \\
\text { que deve ir sim ao enterro } \\
\text { de Manduca, e que pediria à } \\
\text { mãe para ir de sege. } \\
\text { Digressão do narrador sobre } \\
\text { a intenção de ir ao enterro } \\
\text { relacionada a sege; sobre } \\
\text { lembrança de infância dos } \\
\text { passeios na sege; sobre } \\
\text { sege ser antiga e ser uma } \\
\text { lembrança do pai. }\end{array}$ & Não há. \\
\hline
\end{tabular}




\begin{tabular}{|c|c|c|}
\hline $\begin{array}{l}\text { Cap. LXXXIX - } \\
\text { A recusa }\end{array}$ & $\begin{array}{l}\text { Mãe não o deixa ir ao } \\
\text { enterro porque não pode } \\
\text { perder um dia no seminário. } \\
\text { José Dias diz que recusa era } \\
\text { para não dar ao enterro o } \\
\text { lustro da sua presença. } \\
\text { Bentinho fica amuado, mas } \\
\text { depois diz sentir um sabor } \\
\text { nisso. }\end{array}$ & Não há. \\
\hline $\begin{array}{l}\text { Cap. XC - A } \\
\text { polêmica }\end{array}$ & $\begin{array}{l}\text { Bentinho passa pela casa de } \\
\text { Manduca e relembra } \\
\text { polêmica com ele sobre a } \\
\text { Guerra da Criméia, e como } \\
\text { a polêmica ajudou Manduca } \\
\text { a resistir à doença. Lembra } \\
\text { ainda que mesmo sabendo } \\
\text { disso, parou de escrever ao } \\
\text { menino. Por fim, narrador } \\
\text { faz um comentário sobre } \\
\text { episódio, relacionando-o à } \\
\text { morte. }\end{array}$ & Não há. \\
\hline $\begin{array}{l}\text { Cap. XCI - } \\
\text { Achado que } \\
\text { consola }\end{array}$ & $\begin{array}{l}\text { Narrador diz que comentário } \\
\text { não foi feito a caminho do } \\
\text { seminário, mas no gabinete } \\
\text { em Engenho novo. Diz que } \\
\text { na época pensou apenas } \\
\text { que dera alívio e felicidade a } \\
\text { Manduca, e que talvez um } \\
\text { dia seja recompensado por } \\
\text { isso. }\end{array}$ & Não há. \\
\hline $\begin{array}{l}\text { Cap. XCII - O } \\
\text { diabo não é } \\
\text { tão feio com } \\
\text { se pinta }\end{array}$ & $\begin{array}{l}\text { Narrador fecha episódio do } \\
\text { enterro, diz que o tempo e } \\
\text { duas pessoas - Capitu e } \\
\text { uma que será revelada no } \\
\text { próximo capítulo - } \\
\text { apagaram o enterro da } \\
\text { lembrança. Dirige-se ao } \\
\text { leitor e faz novo comentário } \\
\text { sobre o episódio. }\end{array}$ & Não há. \\
\hline
\end{tabular}




\begin{tabular}{|c|c|c|}
\hline $\begin{array}{l}\text { Cap. XCIII - } \\
\text { Um amigo por } \\
\text { um defunto }\end{array}$ & $\begin{array}{l}\text { Reencontra Escobar que o } \\
\text { faz esquecer o defunto. Fala } \\
\text { que ficaram } 5 \text { minutos com } \\
\text { as mãos dadas. Escobar vai } \\
\text { jantar na casa de Bentinho. } \\
\text { Dona Glória o agradece pela } \\
\text { amizade com Bentinho. } \\
\text { Todos gostam de Escobar, } \\
\text { menos Prima J ustina. } \\
\text { Conversa com Escobar, } \\
\text { falam sobre escravos e } \\
\text { casas alugadas. }\end{array}$ & Não há. \\
\hline $\begin{array}{l}\text { Cap. XCIV - } \\
\text { Idéias } \\
\text { aritméticas }\end{array}$ & $\begin{array}{l}\text { Fala da habilidade aritmética } \\
\text { de Escobar, que prefere as } \\
\text { letras aos números. Escobar } \\
\text { soma de cabeça valor dos } \\
\text { aluguéis das casas de Dona } \\
\text { Glória. Bentinho o abraça de } \\
\text { forma efusiva no pátio do } \\
\text { seminário. Outros, entre } \\
\text { eles um padre, os } \\
\text { observam. Amizade se } \\
\text { intensifica. }\end{array}$ & $\begin{array}{l}\text { Essa cena, no roteiro, se dá } \\
\text { no escritório da casa de } \\
\text { Bentinho, num encontro } \\
\text { dos dois casais, com } \\
\text { Bentinho e Capitu já } \\
\text { casados, e não nos tempos } \\
\text { do seminário. Cena está no } \\
\text { capítulo } 11 \text { do roteiro. }\end{array}$ \\
\hline $\begin{array}{l}\text { Cap. XCV - O } \\
\text { Papa }\end{array}$ & $\begin{array}{l}\text { José Dias comunica a } \\
\text { Bentinho que conseguiu } \\
\text { tirá-lo do seminário e que } \\
\text { irão até o Papa para pedir a } \\
\text { absolvição da promessa. } \\
\text { Bentinho pede para pensar } \\
\text { e esconde de J osé Dias que } \\
\text { queria consultar Capitu e } \\
\text { Escobar sobre a viagem. }\end{array}$ & Não há. \\
\hline
\end{tabular}




\begin{tabular}{|c|c|c|}
\hline $\begin{array}{l}\text { Cap. XCVI - } \\
\text { Um substituto }\end{array}$ & $\begin{array}{l}\text { Conversa com Capitu sobre } \\
\text { viagem. Ela não gosta de } \\
\text { idéia, teme que na Europa, } \\
\text { Bentinho a esqueça. } \\
\text { Bentinho fala com Escobar, } \\
\text { que vê uma alternativa à } \\
\text { viagem: um substituto. } \\
\text { Escobar também diz que vai } \\
\text { sair do seminário. }\end{array}$ & Não há. \\
\hline $\begin{array}{l}\text { Cap. XCVII - } \\
\text { A saída }\end{array}$ & $\begin{array}{l}\text { Dona Glória, depois de ouvir } \\
\text { Padre Cabral e Bispo, aceita } \\
\text { idéia de Escobar. Bentinho } \\
\text { sai do seminário no final do } \\
\text { ano, com } 17 \text { anos. Narrador } \\
\text { fala que aqui deveria ser o } \\
\text { meio do livro, mas que } \\
\text { chega quase ao final, com o } \\
\text { melhor da narração por } \\
\text { dizer. Diz que capítulos } \\
\text { agora valerão por meses, } \\
\text { anos. }\end{array}$ & Não há. \\
\hline $\begin{array}{l}\text { Cap. XCVIII - } \\
\text { Cinco anos }\end{array}$ & $\begin{array}{l}\text { Diz que foi estudar e que } \\
\text { em cinco anos se tornou } \\
\text { bacharel. Que nesses cinco } \\
\text { anos, mãe envelheceu. Fala } \\
\text { rapidamente sobre todos os } \\
\text { outros. Sobre Escobar, diz } \\
\text { que continuaram amigos e } \\
\text { que ele aprovara o seu } \\
\text { namoro com Capitu, } \\
\text { ajudando-os na entrega das } \\
\text { cartas. Diz ainda que } \\
\text { Escobar se casará com } \\
\text { Sancha. }\end{array}$ & Não há. \\
\hline $\begin{array}{l}\text { Cap. XCIX - O } \\
\text { filho é a cara } \\
\text { do pai }\end{array}$ & $\begin{array}{l}\text { Descreve volta para casa já } \\
\text { como bacharel. Dona Glória } \\
\text { diz que Bentinho é a cara do } \\
\text { pai. }\end{array}$ & Não há. \\
\hline
\end{tabular}




\begin{tabular}{|c|c|c|}
\hline $\begin{array}{l}\text { Cap. C - "Tu } \\
\text { serás feliz, } \\
\text { Bentinho!" }\end{array}$ & $\begin{array}{l}\text { No quarto, desfazendo a } \\
\text { mala, ouve de uma fada a } \\
\text { frase: "Tu serás feliz, } \\
\text { Bentinho!". J osé Dias diz: "E } \\
\text { por que não seria feliz?". } \\
\text { Bentinho se assusta e } \\
\text { pergunta se ele ouviu. José } \\
\text { Dias disse que sim, afinal, } \\
\text { ele, Bentinho, que a disse. } \\
\text { Relaciona a frase a Macbeth. } \\
\text { José Dias explica porque } \\
\text { Bentinho há de ser feliz, o } \\
\text { elogia, mostra que tem } \\
\text { ciúmes de Escobar, elogia } \\
\text { Capitu, fala do casamento, } \\
\text { que Dona Glória o aprova } \\
\text { etc e etc. Bentinho fala com } \\
\text { Dona Glória sobre } \\
\text { casamento e ela diz: "Tu } \\
\text { serás feliz, meu filho!". }\end{array}$ & $\begin{array}{l}\text { No roteiro, a cena na qual } \\
\text { Bentinho ouve uma voz que } \\
\text { fala que ele será feliz } \\
\text { ocorre com a presença de } \\
\text { Capitu, e não com J osé } \\
\text { Dias. Isso ocorre após o } \\
\text { casamento, no quarto do } \\
\text { casal, e Capitu chega a } \\
\text { imitar ele falando. A cena } \\
\text { ocorre logo após a epístola } \\
\text { de São Pedro, ou seja, a } \\
\text { ordem dos eventos é } \\
\text { invertida, e o interlocutor } \\
\text { de Bentinho é trocado. No } \\
\text { roteiro, essa cena está no } \\
\text { capítulo } 1 .\end{array}$ \\
\hline $\begin{array}{l}\text { Cap. Cl - No } \\
\text { céu }\end{array}$ & $\begin{array}{l}\text { Fala do casamento em } \\
\text { março de } 1865 \text {. Cita as } \\
\text { primeiras epístolas de São } \\
\text { Pedro e faz alguns } \\
\text { comentários sobre a } \\
\text { epístola. }\end{array}$ & $\begin{array}{l}\text { Epístola aparece no início } \\
\text { do roteiro, no capítulo 1, } \\
\text { como legenda sobre uma } \\
\text { cena congelada de } \\
\text { Bentinho e Capitu com as } \\
\text { roupas do casamento. }\end{array}$ \\
\hline $\begin{array}{l}\text { Cap. ClI - De } \\
\text { casada }\end{array}$ & $\begin{array}{l}\text { Fala sobre a primeira } \\
\text { semana de casado. Ele e } \\
\text { Capitu recordam episódios } \\
\text { da infância. Diz que sente } \\
\text { Capitu impaciente, } \\
\text { perguntando do pai e de } \\
\text { Dona Glória, e querendo } \\
\text { descer à cidade. Bentinho } \\
\text { pergunta se ela já está } \\
\text { aborrecida dele. Descem, } \\
\text { narrador relaciona } \\
\text { impaciência de Capitu à } \\
\text { vontade dela de que fosse } \\
\text { vista ou que fossem vistos } \\
\text { casados. Cena deles na rua. }\end{array}$ & $\begin{array}{l}\text { Esses episódios da infância, } \\
\text { não citados de maneira } \\
\text { explicita no livro, podem } \\
\text { ter servido de idéia para os } \\
\text { diálogos ou flashbacks do } \\
\text { roteiro nos capítulos II,III, } \\
\text { IV, V, VI e VII, que } \\
\text { remetem à infância do } \\
\text { casal. Já a pergunta de } \\
\text { Bentinho para o } \\
\text { "aborrecimento" dela está } \\
\text { no capítulo } 7 \text { do roteiro. A } \\
\text { cena deles na rua é } \\
\text { reproduzida no capítulo } 8 \\
\text { do roteiro. }\end{array}$ \\
\hline
\end{tabular}




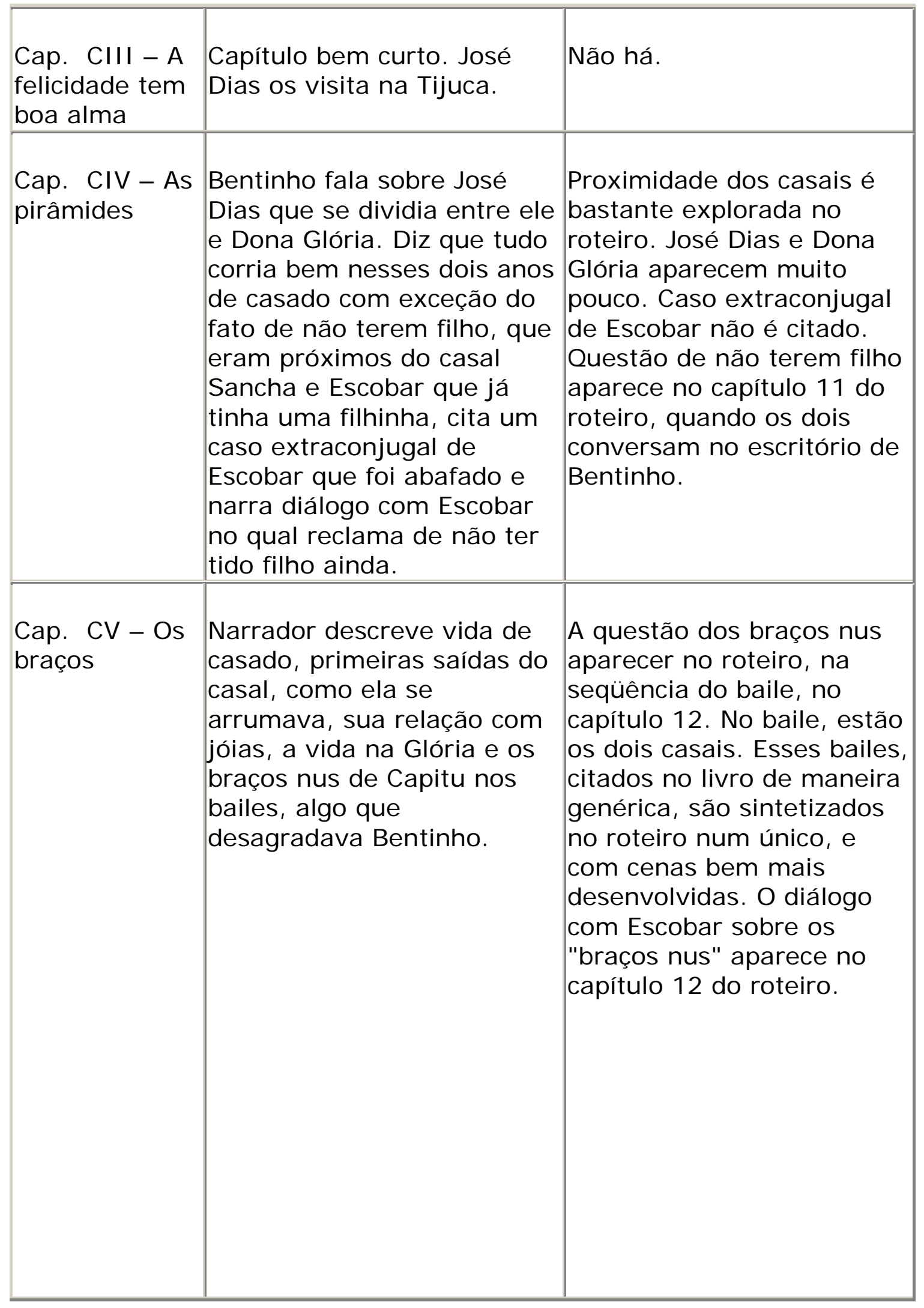




\begin{tabular}{|c|c|c|}
\hline $\begin{array}{l}\text { Cap. CVI - } \\
\text { Dez libras } \\
\text { esterlinas }\end{array}$ & $\begin{array}{l}\text { Narrador rememora diálogo } \\
\text { de Bentinho e Capitu, no } \\
\text { qual ela conta a Bentinho } \\
\text { que guarda algumas } \\
\text { economias e que Escobar a } \\
\text { ajudou. No dia seguinte, } \\
\text { Bentinho encontra com } \\
\text { Escobar e riu com ele do } \\
\text { segredo dele e de Capitu. } \\
\text { Escobar diz que Sanchinha } \\
\text { não era assim. }\end{array}$ & $\begin{array}{l}\text { Cena aparece no capítulo } \\
14 \text { do roteiro. Nesse } \\
\text { momento do roteiro, eles já } \\
\text { sabem que terão um filho. } \\
\text { Diálogos são diferentes e } \\
\text { Bentinho pergunta o que } \\
\text { ela fará com a fortuna. Ela } \\
\text { diz que vai gastar no } \\
\text { enxoval. Bentinho diz: } \\
\text { "Compraremos um berço } \\
\text { de ouro, rendas de ouro, } \\
\text { chocalhos de ouro". }\end{array}$ \\
\hline $\begin{array}{l}\text { Cap. CVII - } \\
\text { Ciúmes do mar }\end{array}$ & $\begin{array}{l}\text { Comenta as conversas de } \\
\text { astronomia com Capitu, sua } \\
\text { desatenção, do ciúme que } \\
\text { tem dela e de como a } \\
\text { amizade com Escobar se } \\
\text { intensifica. }\end{array}$ & $\begin{array}{l}\text { Essas questões estão bem } \\
\text { presentes no roteiro. }\end{array}$ \\
\hline $\begin{array}{l}\text { Cap. CVIII - } \\
\text { Um filho }\end{array}$ & $\begin{array}{l}\text { Fala da dor de não ter um } \\
\text { filho, acentuada pelo fato de } \\
\text { verem a filha de Escobar e } \\
\text { Sancha, Capituzinha. Narra, } \\
\text { depois que o menino } \\
\text { nasceu, que adorava ver } \\
\text { Capitu o amamentando, que } \\
\text { Sancha foi ajudá-la, que } \\
\text { Escobar jantava sempre } \\
\text { com eles e que o menino } \\
\text { recebeu no nome de } \\
\text { Escobar, no caso, Ezequiel. }\end{array}$ & $\begin{array}{l}\text { No roteiro, esses fatos não } \\
\text { estão tão condensados e } \\
\text { são bem mais trabalhados. } \\
\text { Dor por não ter um filho } \\
\text { está no capítulo } 11 \text {, do } \\
\text { roteiro. No 13, após um } \\
\text { baile, Capitu diz a Bentinho } \\
\text { que está grávida. Capitu } \\
\text { amamentando aparece no } \\
\text { roteiro, no capítulo 16, } \\
\text { num piquenique que não } \\
\text { existe no livro. Já toda a } \\
\text { questão do nome aparece } \\
\text { no roteiro, no capítulo } 15 .\end{array}$ \\
\hline $\begin{array}{l}\text { Cap. } \mathrm{CIX}- \\
\text { Um filho único }\end{array}$ & $\begin{array}{l}\text { Capítulo curto, fala sobre o } \\
\text { filho, os cuidados que } \\
\text { despertou pelo fato de ser o } \\
\text { único. }\end{array}$ & $\begin{array}{l}\text { Não há equivalente direto } \\
\text { no roteiro. }\end{array}$ \\
\hline
\end{tabular}




\begin{tabular}{|c|c|c|}
\hline $\begin{array}{l}\text { Cap. CX - } \\
\text { Rasgos da } \\
\text { infância }\end{array}$ & $\begin{array}{l}\text { Ezequiel já conta com cinco } \\
\text { ou seis anos. Bentinho pede } \\
\text { para Capitu tirar ao piano o } \\
\text { pregão do preto das } \\
\text { Cocadas. Ela não se lembra } \\
\text { da toada, só do preto. } \\
\text { Narrador narra momentos } \\
\text { da infância de Ezequiel, } \\
\text { como o do gato que } \\
\text { carregava o rato vivo na } \\
\text { boca. }\end{array}$ & $\begin{array}{l}\text { Cena do rato aparece no } \\
\text { capítulo } 17 \text { do roteiro. Bem } \\
\text { como a do piano. }\end{array}$ \\
\hline $\begin{array}{l}\text { Cap. CXI - } \\
\text { Contado } \\
\text { depressa }\end{array}$ & $\begin{array}{l}\text { Relaciona o episódio do rato } \\
\text { a um outro da infância de } \\
\text { Ezequiel, quando cães } \\
\text { latiam muito e Bentinho } \\
\text { preparou um bolo de carne } \\
\text { com veneno para matá-los. } \\
\text { Só desistiu porque na última } \\
\text { hora os cães lhe } \\
\text { demonstraram algum afeto. }\end{array}$ & Não há. \\
\hline $\begin{array}{l}\text { Cap. CXII - } \\
\text { As imitações } \\
\text { de Ezequiel }\end{array}$ & $\begin{array}{l}\text { Narrador relata diálogo de } \\
\text { Capitu e Bentinho sobre o } \\
\text { defeito do menino de imitar } \\
\text { os outros. }\end{array}$ & $\begin{array}{l}\text { Cena aparece no capítulo } \\
17 \text { do roteiro. }\end{array}$ \\
\hline $\begin{array}{l}\text { Cap. CXIII - } \\
\text { Embargos de } \\
\text { terceiro }\end{array}$ & $\begin{array}{l}\text { Narrador fala do ciúme que } \\
\text { tinha por Capitu. E narra o } \\
\text { episódio no qual foi ao } \\
\text { teatro sozinho porque } \\
\text { Capitu estava doente, e na } \\
\text { volta, no final do primeiro } \\
\text { ato, encontrou Escobar na } \\
\text { porta de sua casa. Escobar } \\
\text { disse que foi procurá-lo para } \\
\text { tratar de uma ação, de uns } \\
\text { embargos. }\end{array}$ & $\begin{array}{l}\text { Episódio está distendido } \\
\text { nos capítulo } 18,19 \text { e } 20 \text { do } \\
\text { roteiro. }\end{array}$ \\
\hline
\end{tabular}




\begin{tabular}{|c|c|c|}
\hline $\begin{array}{l}\text { Cap. CXIV - } \\
\text { Em que se } \\
\text { explica o } \\
\text { explicado }\end{array}$ & $\begin{array}{l}\text { Narrador remete leitor a } \\
\text { capítulo CX no qual há a } \\
\text { menção à toada do pregão } \\
\text { de doces, e ao fato de } \\
\text { Capitu não se lembrar do } \\
\text { juramento que fez, de que } \\
\text { jamais esqueceria aquele } \\
\text { momento. Relaciona isso a } \\
\text { uma infidelidade da parte } \\
\text { dela. }\end{array}$ & $\begin{array}{l}\text { Há menção a esse } \\
\text { esquecimento no capítulo } \\
17 \text { do roteiro, mas não com } \\
\text { o mesmo rendimento do } \\
\text { livro. }\end{array}$ \\
\hline $\begin{array}{l}\text { Cap. CXV - } \\
\text { Dúvidas sobre } \\
\text { dúvidas }\end{array}$ & $\begin{array}{l}\text { Volta à questão dos } \\
\text { embargos, retomando } \\
\text { capítulo com Escobar e } \\
\text { Bentinho tomando chá. Fala } \\
\text { de suas dúvidas a respeito } \\
\text { de Capitu, e principalmente } \\
\text { da frieza de Dona Glória } \\
\text { com eles e com Ezequiel. } \\
\text { Vão jantar com Dona Glória. } \\
\text { Na volta, Bentinho e Capitu } \\
\text { falam sobre Dona Glória. } \\
\text { Capitu disse que isso era } \\
\text { normal. Narrador diz que } \\
\text { Capitu está cada dia mais } \\
\text { doce com Bentinho. }\end{array}$ & $\begin{array}{l}\text { Cena do chá está no } \\
\text { capítulo } 20 \text { do roteiro. Bem } \\
\text { como preocupação com o } \\
\text { afastamento da mãe. } \\
\text { Capítulo termina com } \\
\text { Bentinho dizendo que } \\
\text { precisa visitá-la. Mas, a } \\
\text { visita não está no roteiro. }\end{array}$ \\
\hline $\begin{array}{l}\text { Cap. CXVI - } \\
\text { Filho do } \\
\text { homem }\end{array}$ & $\begin{array}{l}\text { Fala com José Dias sobre } \\
\text { frieza de Dona Glória. } \\
\text { Agregado fica espantado e } \\
\text { diz que Dona Glória é só } \\
\text { elogios a Capitu. Diz } \\
\text { também que ele se } \\
\text { arrepende de ter sido contra } \\
\text { o casamento. Falam da } \\
\text { mania de Ezequiel de imitar } \\
\text { os outros, inclusive José } \\
\text { Dias. }\end{array}$ & $\begin{array}{l}\text { Cena está no capítulo } 21 \text { do } \\
\text { roteiro. Elogios a Capitu } \\
\text { não estão e nem } \\
\text { arrependimento de José } \\
\text { Dias. Imitação de Ezequiel } \\
\text { sim. Menino começa a } \\
\text { imitar a pedido de José } \\
\text { Dias. Bentinho e Capitu } \\
\text { repreendem o garoto. }\end{array}$ \\
\hline
\end{tabular}




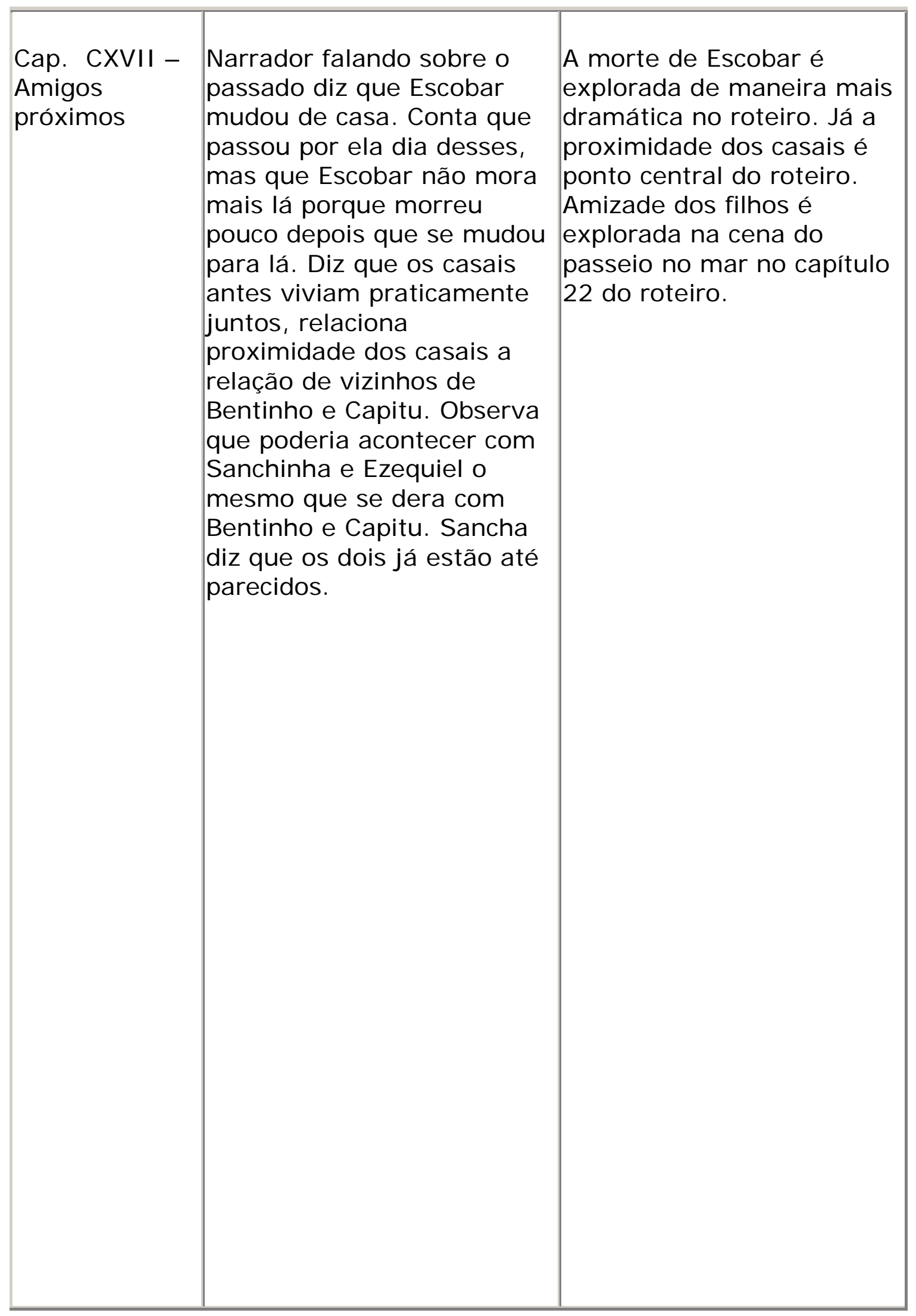




\begin{tabular}{|c|c|c|}
\hline $\begin{array}{l}\text { Cap. CXVIII - } \\
\text { A mão de } \\
\text { Sancha }\end{array}$ & $\begin{array}{l}\text { Escobar chama Bentinho } \\
\text { para anunciar um projeto } \\
\text { para os dois casais: uma } \\
\text { viagem à Europa. Estão } \\
\text { também na casa de } \\
\text { Escobar, J osé Dias e Prima } \\
\text { Justina. Bentinho olha } \\
\text { Sancha de forma diferente. } \\
\text { Escobar fala do mar bravio, } \\
\text { da ressaca do mar e do } \\
\text { desafio que é nadar nestas } \\
\text { condições. Bentinho aperta- } \\
\text { Ihe os braços pensando nos } \\
\text { de Sancha e inveja o fato de } \\
\text { serem mais grossos que os } \\
\text { seus. Na saída, Sancha } \\
\text { aperta a mão de Bentinho } \\
\text { por mais tempo que o } \\
\text { costume. Voltam } \\
\text { conversando, Bentinho e } \\
\text { J osé Dias, Prima Justina e } \\
\text { Capitu. Em casa, Bentinho } \\
\text { se recolhe ao seu gabinete, } \\
\text { pensa em Sancha, na } \\
\text { deslealdade com o amigo, } \\
\text { sente remorso. }\end{array}$ & $\begin{array}{l}\text { Menção a gosto de Escobar } \\
\text { pela natação aparece pela } \\
\text { primeira vez no capítulo } 8 \\
\text { do roteiro, quando } \\
\text { Bentinho Ihe pergunta } \\
\text { porque está tão magro. } \\
\text { Dado é bem marcado no } \\
\text { roteiro, seja por falas de } \\
\text { Escobar ou Bentinho, seja } \\
\text { pela repetição da condição } \\
\text { do mar. } \\
\text { Aperto de mão de Sancha } \\
\text { em Bentinho está no } \\
\text { capítulo } 23 \text { do roteiro. } \\
\text { Recolhimento de Bentinho } \\
\text { ao escritório ocorre no } \\
\text { capítulo } 25 \text { do roteiro e é } \\
\text { bem mais desenvolvida que } \\
\text { no livro. }\end{array}$ \\
\hline $\begin{array}{l}\text { Cap. CXIX - } \\
\text { Não faça isso, } \\
\text { querida }\end{array}$ & $\begin{array}{l}\text { Capítulo curto. Cita leitora, } \\
\text { fala que ela pode querer } \\
\text { fechar o livro porque beiram } \\
\text { um abismo, mas que } \\
\text { mudará de rumo. }\end{array}$ & Não há. \\
\hline $\begin{array}{l}\text { Cap. CXX - } \\
\text { Autos }\end{array}$ & $\begin{array}{l}\text { Narra manhã seguinte, se } \\
\text { diz livre das alucinações da } \\
\text { véspera. Estuda um } \\
\text { processo. }\end{array}$ & $\begin{array}{l}\text { Está no capítulo } 27 \text { do } \\
\text { roteiro. }\end{array}$ \\
\hline $\begin{array}{l}\text { Cap. CXXI - A } \\
\text { catástrofe }\end{array}$ & $\begin{array}{l}\text { Escravo de Sancha traz a } \\
\text { notícia da morte de Escobar. }\end{array}$ & $\begin{array}{l}\text { Está no capítulo } 27 \text { e } 28 \text { do } \\
\text { roteiro. }\end{array}$ \\
\hline
\end{tabular}




\begin{tabular}{|c|c|c|}
\hline $\begin{array}{l}\text { Cap. CXXII - } \\
\text { O enterro }\end{array}$ & $\begin{array}{l}\text { Descreve preparativo do } \\
\text { enterro, falatório a respeito } \\
\text { da morte, o que finado } \\
\text { havia deixado, lembra da } \\
\text { amizade de infância e } \\
\text { prepara seu discurso para o } \\
\text { enterro. }\end{array}$ & $\begin{array}{l}\text { Velório e enterro estão no } \\
\text { capítulo } 29 \text { do roteiro. } \\
\text { Roteiro não trata destas } \\
\text { questões. Discurso é pouco } \\
\text { citado e roteiro não se } \\
\text { ocupa da preocupação de } \\
\text { Bentinho com ele. }\end{array}$ \\
\hline $\begin{array}{l}\text { Cap. CXXIII - } \\
\text { Olhos de } \\
\text { ressaca }\end{array}$ & $\begin{array}{l}\text { Capítulo curto, sobre a hora } \\
\text { da encomenda do corpo e } \\
\text { olhar de Capitu para o } \\
\text { morto. }\end{array}$ & $\begin{array}{l}\text { Está no capítulo } 29 \text { do } \\
\text { roteiro. Neste, Capitu se } \\
\text { agarra ao caixão. }\end{array}$ \\
\hline $\begin{array}{l}\text { Cap. CXXIV - } \\
\text { O Discurso }\end{array}$ & $\begin{array}{l}\text { Pensa em atirar à rua, o } \\
\text { caixão, o defunto, tudo. Em } \\
\text { crise, lê o discurso. }\end{array}$ & $\begin{array}{l}\text { No capítulo } 29 \text { do roteiro, } \\
\text { Bentinho fica } \\
\text { desconcertado com atitude } \\
\text { Capitu, mas não pensa em } \\
\text { atirar tudo à rua. }\end{array}$ \\
\hline $\begin{array}{l}\text { Cap. CXXV - } \\
\text { Uma } \\
\text { comparação }\end{array}$ & Compara-se a Príamo. & Não há. \\
\hline $\begin{array}{l}\text { Cap. CXXVI - } \\
\text { Cismando }\end{array}$ & $\begin{array}{l}\text { Narra saída do cemitério, diz } \\
\text { que rasgou discurso, deixou } \\
\text { José Dias falando sozinho e } \\
\text { saiu do carro, voltando para } \\
\text { casa sozinho com suas } \\
\text { cismas. }\end{array}$ & $\begin{array}{l}\text { Está no capítulo } 30 \text { do } \\
\text { roteiro. Não há evento do } \\
\text { discurso. No roteiro, } \\
\text { passagem é bem mais } \\
\text { desenvolvida. }\end{array}$ \\
\hline $\begin{array}{l}\text { Cap. CXXVII - } \\
\text { o barbeiro }\end{array}$ & $\begin{array}{l}\text { Pára num barbeiro perto de } \\
\text { sua casa, ouve barbeiro } \\
\text { tocar a rabeca. Volta para } \\
\text { casa. }\end{array}$ & $\begin{array}{l}\text { Está no capítulo } 30 \text { do } \\
\text { roteiro. No roteiro, } \\
\text { passagem é bem mais } \\
\text { desenvolvida. }\end{array}$ \\
\hline
\end{tabular}




\begin{tabular}{|c|c|c|}
\hline $\begin{array}{l}\text { Cap. CXXVIII } \\
\text { - Punhado de } \\
\text { sucessos }\end{array}$ & $\begin{array}{l}\text { Retoma capítulo anterior, } \\
\text { sobe as escadas, dá de cara } \\
\text { com Prima Justina e José } \\
\text { Dias. Capitu vem falar com } \\
\text { ele, falam de Sancha e da } \\
\text { menina que fica. No dia } \\
\text { seguinte, Bentinho se } \\
\text { arrepende de ter rasgado o } \\
\text { discurso, tenta recompô-lo. } \\
\text { Inventaria as lembranças de } \\
\text { Escobar, fala das notícias } \\
\text { sobre a morte, sobre o } \\
\text { testamento, e que Sancha } \\
\text { se mudou tempos depois } \\
\text { para a casa de parentes no } \\
\text { Paraná. }\end{array}$ & $\begin{array}{l}\text { No roteiro, não existe a } \\
\text { figura da Prima Justina e } \\
\text { toda a ação se passa à } \\
\text { noite, concentrando-se na } \\
\text { cisma de Bentinho que } \\
\text { evita Capitu e a censura } \\
\text { por não ter ficado com } \\
\text { Sancha. Não há menção ao } \\
\text { discurso, inventário, } \\
\text { lembranças de Escobar, } \\
\text { notícias sobre a morte, } \\
\text { testamento e mudança de } \\
\text { Sancha. }\end{array}$ \\
\hline $\begin{array}{l}\text { Cap. CXXIX - } \\
\text { A D. Sancha }\end{array}$ & $\begin{array}{l}\text { Dom Casmurro escreve } \\
\text { Carta a Sancha para não ler } \\
\text { o livro que ele escreve. "Vá } \\
\text { envelhecendo, sem marido } \\
\text { nem filha, que eu faço a } \\
\text { mesma cousa }(. . .) " .\end{array}$ & Não há. \\
\hline $\begin{array}{l}\text { Cap. CXXX - } \\
\text { Um dia }\end{array}$ & $\begin{array}{l}\text { Capitu quer saber porque } \\
\text { Bentinho está tão calado, } \\
\text { sugere viagem, bailes e } \\
\text { outros remédios para a } \\
\text { melancolia. Ele diz que } \\
\text { negócios vão mal. Ela } \\
\text { sugere vender coisas. Ele } \\
\text { diz que não é preciso. } \\
\text { Narrador pede perdão, mas } \\
\text { que um outro capítulo } \\
\text { deveria vir antes deste. }\end{array}$ & Não há. \\
\hline $\begin{array}{l}\text { Cap. CXXXI - } \\
\text { Anterior ao } \\
\text { anterior }\end{array}$ & $\begin{array}{l}\text { Capitu fala que Ezequiel tem } \\
\text { uma expressão esquisita } \\
\text { nos olhos, iguais ao de } \\
\text { Escobar e de um amigo de } \\
\text { Pádua. Bentinho concorda. }\end{array}$ & Não há. \\
\hline
\end{tabular}




\begin{tabular}{|c|c|c|}
\hline $\begin{array}{l}\text { Cap. CXXXII - } \\
\text { O debuxo e o } \\
\text { colorido }\end{array}$ & $\begin{array}{l}\text { Narrador diz que não só os } \\
\text { olhos, mas tudo ia se } \\
\text { apurando com o tempo. } \\
\text { Relata o desconforto } \\
\text { enorme de Bentinho diante } \\
\text { da semelhança do filho com } \\
\text { Escobar. Narrador usa a } \\
\text { palavra comborço ao citar } \\
\text { Escobar. Ezequiel os } \\
\text { separava cada vez mais. } \\
\text { Colocam-no num colégio } \\
\text { interno. Mas, presença do } \\
\text { menino, mesmo no final de } \\
\text { semana, atormenta } \\
\text { Bentinho. }\end{array}$ & $\begin{array}{l}\text { Não há. } \\
\text { Palavra comborço que é } \\
\text { usada aqui pelo narrador } \\
\text { ganha destaque no roteiro } \\
\text { no capítulo } 35 . \\
\text { No roteiro, não há menção } \\
\text { ao colégio interno. }\end{array}$ \\
\hline $\begin{array}{l}\text { Cap. CXXXIII } \\
\text { - Uma idéia }\end{array}$ & $\begin{array}{l}\text { Capítulo curto, Bentinho } \\
\text { tem uma idéia, mas a deixa } \\
\text { para o capítulo seguinte. }\end{array}$ & Não há \\
\hline $\begin{array}{l}\text { Cap. CXXXIV } \\
- \text { O dia de } \\
\text { sábado }\end{array}$ & $\begin{array}{l}\text { Fala sobre a idéia que teve. } \\
\text { Escreve cartas e sai para } \\
\text { comprar uma substância, } \\
\text { pensa em suicídio. }\end{array}$ & $\begin{array}{l}\text { I déia do veneno está no } \\
\text { roteiro, mas depois da ida } \\
\text { ao teatro, no capítulo } 34 . \\
\text { Cartas estão no capítulo } \\
35 .\end{array}$ \\
\hline $\begin{array}{l}\text { Cap. CXXXV - } \\
\text { Otelo }\end{array}$ & $\begin{array}{l}\text { Narra ida ao teatro, foi ver } \\
\text { Otelo. Admite coincidência } \\
\text { com relação ao momento } \\
\text { que vive. Fala sobre o lenço. } \\
\text { O último ato mostrou que } \\
\text { não ele, mas Capitu deveria } \\
\text { morrer. Vaga pelas ruas. } \\
\text { Chega na casa às } 6 \text { horas, } \\
\text { pega o veneno e fica no } \\
\text { gabinete. Escreve uma carta } \\
\text { a Capitu para que ela } \\
\text { sentisse remorso da sua } \\
\text { morte. }\end{array}$ & $\begin{array}{l}\text { Cena está no capítulo } 33 \text { do } \\
\text { roteiro que a desenvolve, } \\
\text { citando vários diálogos da } \\
\text { peça. No roteiro, Bentinho } \\
\text { sai antes do término, pois } \\
\text { confunde Capitu e } \\
\text { Desdêmona a si próprio } \\
\text { com Otelo, ouve também } \\
\text { vozes que falam com ele. } \\
\text { Cena de Bentinho no } \\
\text { escritório, escrevendo } \\
\text { cartas está no capítulo } 35 \\
\text { do roteiro. }\end{array}$ \\
\hline
\end{tabular}




\begin{tabular}{|c|c|c|}
\hline $\begin{array}{l}\text { Cap. CXXXVI } \\
\text { - Xícara de } \\
\text { café }\end{array}$ & $\begin{array}{l}\text { Plano de Bentinho era } \\
\text { esperar o café, dissolver o } \\
\text { veneno e ingeri-lo. Quer ler } \\
\text { Platão antes da morte, } \\
\text { como fez Catão, mas só } \\
\text { achou um tomo de Plutarco. } \\
\text { Copeiro chega com o café. } \\
\text { Hesita em beber a mistura, } \\
\text { pensa em esperar Ezequiel e } \\
\text { Capitu irem à missa. } \\
\text { Ezequiel entra no gabinete. }\end{array}$ & $\begin{array}{l}\text { Cena está no capítulo } 36 \text { do } \\
\text { roteiro. Não há menção a } \\
\text { Platão e Plutarco. }\end{array}$ \\
\hline $\begin{array}{l}\text { Cap. CXXXVII } \\
\text { - Segundo } \\
\text { impulso } \\
\end{array}$ & \begin{tabular}{|l||} 
Diz narrador que se não \\
fosse o fato de ter visto \\
Ezequiel, ele não estaria \\
escrevendo o livro agora. \\
Pergunta ao menino se já \\
tomara café. Escobar diz \\
que sim. Bentinho Ihe \\
oferece a bebida. Menino \\
pergunta: "E o papai?". \\
Bentinho insiste e diz que \\
pediria mais para ele. \\
Ezequiel chega a abrir a \\
boca. Bentinho hesita e \\
passa a beijar doudamente \\
o menino que estranha a \\
atitude do pai. Bentinho diz \\
para Escobar que não é seu \\
pai.
\end{tabular} & $\begin{array}{l}\text { Não há o comentário do } \\
\text { narrador. Restante da cena } \\
\text { está no capítulo } 36 \text { do } \\
\text { roteiro. }\end{array}$ \\
\hline $\begin{array}{l}\text { Cap. CXXXVIII } \\
\text { - Capitu que } \\
\text { entra }\end{array}$ & $\begin{array}{l}\text { Retoma capítulo anterior, } \\
\text { Capitu entra, pede que o } \\
\text { filho saia e pede explicações } \\
\text { a Bentinho. Bentinho repete } \\
\text { que Ezequiel não é filho } \\
\text { dele. Capitu diz que quer se } \\
\text { separar, que nem os mortos } \\
\text { escapam ao ciúme de } \\
\text { Bentinho e que a culpa de } \\
\text { tudo é a casualidade da } \\
\text { semelhança. }\end{array}$ & $\begin{array}{l}\text { Cena está no capítulo } 36 \text { do } \\
\text { roteiro. }\end{array}$ \\
\hline
\end{tabular}




\begin{tabular}{|c|c|c|}
\hline $\begin{array}{l}\text { Cap. CXXXIX } \\
\text { - A fotografia }\end{array}$ & $\begin{array}{l}\text { Capítulo curto, narrador diz } \\
\text { que esteve a pique de crer } \\
\text { que era vítima de uma } \\
\text { grande ilusão, mas que } \\
\text { entrada de Ezequiel gritando } \\
\text { que era hora da missa o } \\
\text { reconstitui a consciência da } \\
\text { realidade. Capitu e Bentinho } \\
\text { olham fotografia de Escobar. } \\
\text { Capitu pega o filho e sai } \\
\text { com ele. }\end{array}$ & $\begin{array}{l}\text { Cena está no capítulo } 36 \text { do } \\
\text { roteiro. } \\
\end{array}$ \\
\hline $\begin{array}{l}\text { Cap. CXL - } \\
\text { Volta da Igreja }\end{array}$ & $\begin{array}{l}\text { Narrador diz que com } \\
\text { Bentinho só no gabinete, o } \\
\text { mais natural era que } \\
\text { bebesse o café, mas que } \\
\text { este tinha perdido o gosto } \\
\text { da morte. Bentinho espera } \\
\text { Capitu retornar da I greja. } \\
\text { Ela volta e diz que } \\
\text { separação é indispensável e } \\
\text { que está às ordens dele. }\end{array}$ & $\begin{array}{l}\text { Cena está no capítulo } 36 \text { do } \\
\text { roteiro, mas termina com } \\
\text { Capitu saindo para missa. } \\
\text { Antes de ir à missa, ela já } \\
\text { sabe e aceita a separação e } \\
\text { a viagem à Europa. }\end{array}$ \\
\hline $\begin{array}{l}\text { Cap. CXLI - A } \\
\text { solução }\end{array}$ & $\begin{array}{l}\text { Vão à Europa. Bentinho } \\
\text { deixa Capitu e Ezequiel na } \\
\text { Suíça. Capitu ao longo de } \\
\text { um ano lhe escreve cartas. } \\
\text { Bentinho retorna duas vezes } \\
\text { para lá, mas não a procura. } \\
\text { Usa a viagem apenas para } \\
\text { enganar os outros. }\end{array}$ & Não há. \\
\hline $\begin{array}{l}\text { Cap. CXLII - } \\
\text { Uma santa }\end{array}$ & $\begin{array}{l}\text { Morre Dona Glória, Bentinho } \\
\text { manda escrever na } \\
\text { sepultura: "Uma santa..." }\end{array}$ & Não há. \\
\hline $\begin{array}{l}\text { Cap. CXLIII - } \\
\text { O último } \\
\text { superlativo }\end{array}$ & Narra a morte de José Dias. & Não há. \\
\hline
\end{tabular}




\begin{tabular}{|c|c|c|}
\hline $\begin{array}{l}\text { Cap. CXLIV - } \\
\text { Uma pergunta } \\
\text { tardia }\end{array}$ & $\begin{array}{l}\text { Dom Casmurro fala que } \\
\text { mora longe e que sai pouco. } \\
\text { Retoma idéia da construção } \\
\text { da casa de Matacavalos e } \\
\text { explica porque, tendo a } \\
\text { casa, deixou demoli-la para } \\
\text { depois querer reconstruí-la. } \\
\text { Explica que logo depois da } \\
\text { morte da mãe, toda a casa } \\
\text { o desconheceu. }\end{array}$ & Não há. \\
\hline $\begin{array}{l}\text { Cap. CXLV - } \\
\text { O regresso }\end{array}$ & $\begin{array}{l}\text { Ezequiel o visita na casa } \\
\text { nova. Narrador cita que mãe } \\
\text { dele, Capitu, já estava } \\
\text { morta e enterrada. Vê } \\
\text { Ezequiel muito parecido com } \\
\text { Escobar. Narrador diz que } \\
\text { Capitu elogiava muito } \\
\text { Bentinho ao filho, dizia que } \\
\text { era o homem mais puro do } \\
\text { mundo. Almoçam. Dom } \\
\text { Casmurro mal olha para } \\
\text { Ezequiel para não lembrar } \\
\text { do defunto. Moram juntos. } \\
\text { Prima J ustina morre. } \\
\text { Ezequiel fala que pensa em } \\
\text { viajar. Dom Casmurro Ihe } \\
\text { dá dinheiro para a viagem. }\end{array}$ & Não há. \\
\hline $\begin{array}{l}\text { Cap. CXLVI - } \\
\text { Não houve } \\
\text { lepra }\end{array}$ & $\begin{array}{l}\text { Onze meses depois, } \\
\text { Ezequiel morre de febre } \\
\text { tifóide. Dom Casmurro, no } \\
\text { mesmo capítulo, diz que } \\
\text { jantou bem e foi ao teatro. }\end{array}$ & Não há. \\
\hline $\begin{array}{l}\text { Cap. CXLVII - } \\
\text { A exposição } \\
\text { Retrospectiva }\end{array}$ & $\begin{array}{l}\text { Casmurro diz que viveu } \\
\text { depois o melhor que pôde e } \\
\text { que não faltaram amigas } \\
\text { para o consolarem. }\end{array}$ & Não há. \\
\hline
\end{tabular}




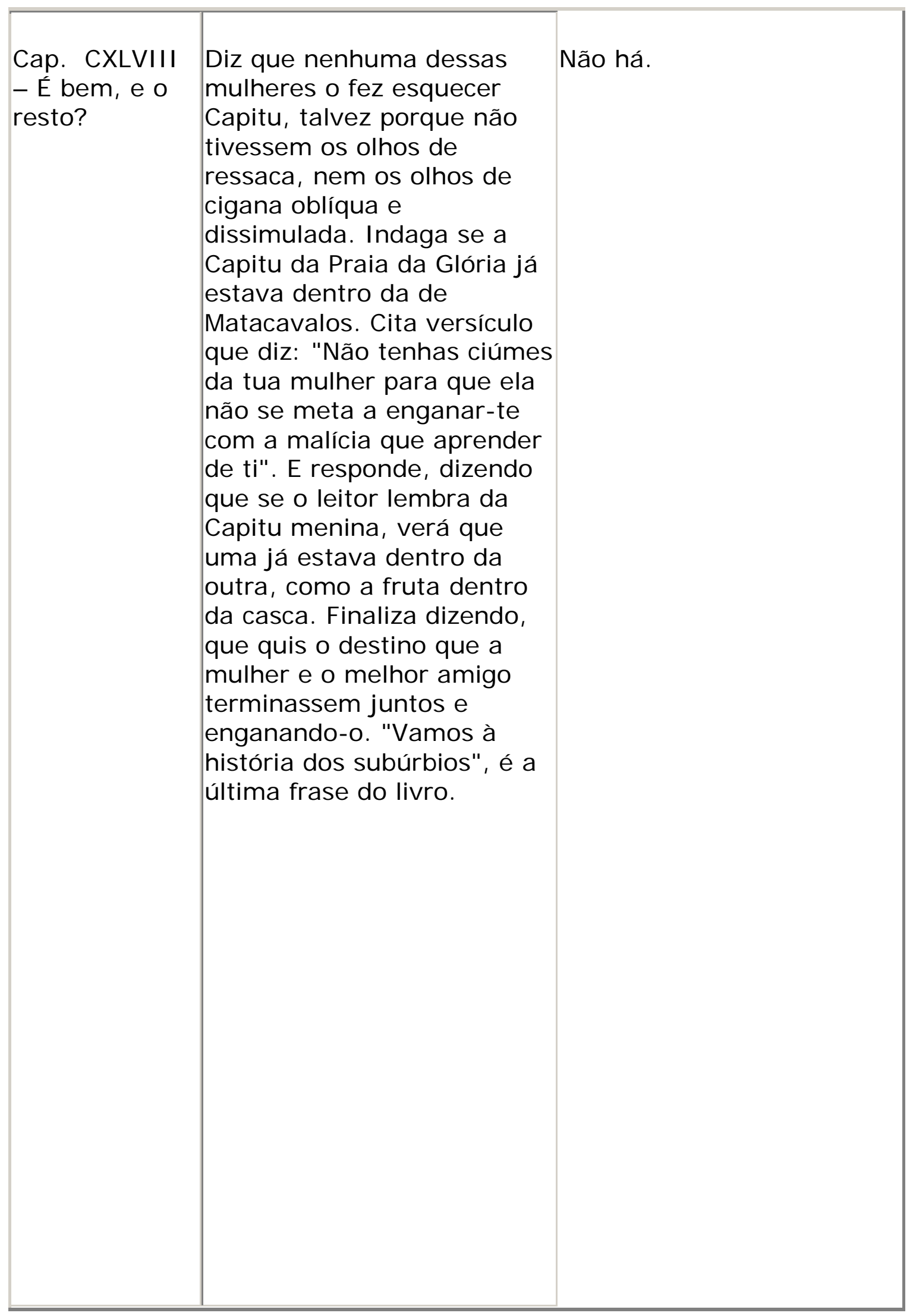


